\title{
Análisis de los Decretos emitidos por el Poder Ejecutivo de la Provincia de Buenos Aires durante el año 2019
}

\author{
Analysis of the decrees issued by the Executive \\ Power of the Province of Buenos Aires during \\ 2019
}

\author{
Esteban F. Taglianetti ${ }^{1}$, Mariano Raffo ${ }^{2}$, \\ María Victoria Simioni ${ }^{3}$,Erika Deantoni Mosca ${ }^{4}$, \\ Fernando Novelli, Guillermina Fernández ${ }^{6}$, \\ Jacqueline Grace ${ }^{7}$, Mía Lasalvia ${ }^{8}$, Noelia Bertoni ${ }^{9}$, \\ Victoria Credaro ${ }^{10}$, Facundo Aravena ${ }^{11}$ \\ Universidad Nacional de La Plata - Argentina
}

1 Abogado, Universidad Nacional de La Plata - Facultad de Ciencias Jurídicas y Sociales. E-mail: estebantaglianetti@gmail.com (ORCID: https://orcid.org/0000-0001-5809-9881).

2 Contador Público, Universidad Nacional de La Plata - Facultad de Ciencias Económicas. E-mail: mariano_raffo@hotmail.com (ORCID: https://orcid.org/0000-0001-7305-2184).

3 Abogada, Universidad Nacional de La Plata - Facultad de Ciencias Jurídicas y Sociales. E-mail: victoriasimioni@gmail.com (ORCID: https://orcid.org/0000-0003-0172-9963).

4 Abogada, Universidad Nacional de La Plata - Facultad de Ciencias Jurídicas y Sociales. E-mail: erikadeant@yahoo.com.ar (ORCID: https://orcid.org/0000-0001-6503-8219).

5 Abogado, Universidad Nacional de La Plata - Facultad de Ciencias Jurídicas y Sociales. E-mail: fernovelli@yahoo.com.ar (ORCID: https://orcid.org/0000-0002-5437-5372).

6 Abogada, Universidad Nacional de La Plata - Facultad de Ciencias Jurídicas y Sociales. E-mail: guillefb23@gmail.com (ORCID: https://orcid.org/0000-0002-6332-864X).

7 Lic. en Administración, Universidad Nacional de La Plata - Facultad de Ciencias Económicas. E-mail: jacquigrace.89@gmail.com (ORCID: https://orcid.org/0000-0002-2574-030X).

8 Abogada, Universidad Nacional de La Plata - Facultad de Ciencias Jurídicas y Sociales. E-mail: mialasalvia@hotmail.com (ORCID: https://orcid.org/0000-0002-0690-142X).

9 Abogada, Universidad Nacional de La Plata - Facultad de Ciencias Jurídicas y Sociales. E-mail: noeliabertoni@outlook.com (ORCID: https://orcid.org/0000-0002-2303-505X).

10 Abogada, Universidad Nacional de La Plata - Facultad de Ciencias Jurídicas y Sociales. E-mail: victoriacredaro@gmail.com (ORCID: https://orcid.org/0000-0001-7662-1493).

11 Lic. en Administración, Universidad Nacional de La Plata - Facultad de Ciencias Económicas. E-mail: facundoaravena@hotmail.com (ORCID: https://orcid.org/0000-0001-6470-9025). 


\section{Daniel Herrera ${ }^{12}$, Darío González ${ }^{13}$ Universidad Católica de La Plata - Argentina \\ Guillermo Comadira ${ }^{14}$ Universidad Austral - Argentina}

Revista Derechos en Acción ISSN 2525-1678/ e-ISSN 2525-1686

Año 5/N 17 Primavera 2020 (21 septiembre a 20 diciembre), 498-603

DOl: https://doi.org/10.24215/25251678e469

Recibido: 25/10/2020

Aprobado: 15/11/2020

Resumen: El presente trabajo es el resultado de un proceso de investigación que tuvo como objeto de estudio el análisis de los decretos dictados por la Gobernadora saliente de la provincia de Buenos Aires durante el 2019. El propósito principal de esta propuesta es aportar una descripción sobre una significativa porción de la actividad desarrollada por el Poder Ejecutivo durante el año demarcado, cuya importancia reside, en primer lugar, en el volumen de decretos analizados -un total de mil ochocientos sesenta y tres (1863); en segundo lugar, en la actualidad e importancia de la información que presentan -dado que 2019 es el último año de su gestión-; y, por último, en la diversidad de datos que estos documentos ilustran. En ese sentido, en el curso de la investigación se procedió a la búsqueda y recopilación de la totalidad de los decretos emitidos durante el período comprendido entre el $1^{\circ}$ de enero y el 10 de diciembre del año referenciado. A continuación, a partir de la compilación normativa efectuada y del estudio de los procesos administrativos involucrados, se llevaron a cabo las tareas de lectura y análisis de la totalidad de los decretos,

12 Abogado, Facultad de Derecho - Universidad Católica de La Plata. E-mail: daniel27herrera@gmail.com (ORCID: https://orcid.org/0000-0002-2974-8499).

$135^{\circ}$ año cursado, Licenciatura en Ciencias Políticas y Relaciones Internacionales, Facultad de Ciencias Sociales - Universidad Católica de La Plata E-mail: gonzalezdvm@gmail.com (ORCID: https://orcid.org/0000-0003-1570-3211).

14 Abogado. E-mail: gcomadira@hotmail.com (ORCID: https://orcid.org/0000-0003-2172-4027). 
de creación de una base de datos específica y la sistematización de los resultados. La última tarea realizada ha sido la difusión de la investigación mediante la elaboración del presente artículo, que ofrece un análisis de tipo estadístico que dimensiona la actividad desarrollada y que, además, permite visualizar información variada relativa a los plazos que insume cada proceso, a las áreas intervinientes y a los resultados obtenidos.

Palabras clave: Decretos, Poder Ejecutivo, Provincia de Buenos Aires, Administración Pública.

Abstract: The present work is the result of a research process whose object of study was the analysis of the decrees issued by the outgoing Governor of the province of Buenos Aires during 2019. The main purpose of this proposal is to provide a description of a significant portion of the activity carried out by the Executive Power during the demarcated year, the importance of which resides, first, in the volume of decrees analyzed - a total of one thousand eight hundred and sixty-three (1863); secondly, the current and importance of the information they present -since 2019 is the last year of their administration-; and, finally, in the diversity of data that these documents illustrate. In that sense, during the course of the investigation, all the decrees issued during the period between January 1 and December 10 of the referenced year were searched and compiled. Then, based on the regulatory compilation carried out and the study of the administrative processes involved, the tasks of reading and analysis of all the decrees, the creation of a specific database and the systematization of the results were carried out. . The last task carried out has been the dissemination of the research through the preparation of this article, which offers a statistical analysis that measures the activity carried out and which, in addition, allows the visualization of various information related to the deadlines that each process takes, the intervening areas and the results obtained

Keywords: Decrees, Executive Power, Province of Buenos Aires, Public Administration.

\section{Introducción: Notas a la investigación sobre los decretos bonaerenses 2019}

El presente trabajo es el resultado de un proceso de investigación que tuvo como objeto de estudio el análisis de los 
decretos dictados por la Gobernadora saliente de la provincia de Buenos Aires durante el 2019. Es decir, se examinaron los actos administrativos dictados por María Eugenia Vidal en el período comprendido entre el $1^{\circ}$ de enero y el 10 de diciembre del año referenciado, fecha a partir de la cual asumió la titularidad del Poder Ejecutivo provincial Axel Kicillof. ${ }^{15}$

A su vez, cabe destacar que esta investigación se incorpora dentro de un plan más ambicioso de estudiar e indagar respecto de los decretos emanados del Poder Ejecutivo de la provincia de Buenos Aires durante el período constitucional 2015-2019; siendo ésta entrega la segunda. ${ }^{16}$

El propósito principal de esta propuesta es aportar una descripción sobre una significativa porción de la actividad desarrollada por la ex-Gobernadora durante el año demarcado, cuya importancia reside, en primer lugar, en el volumen de decretos analizados -un total de mil ochocientos sesenta y tres (1863); en segundo lugar, en la actualidad de la información que presentan -dado que 2019 es el último año de su gestión-; y, por último, en la diversidad de datos que estos documentos ilustran.

Asimismo, teniendo presente que ya hemos publicado la investigación respecto del período 2018, se practicará un comparativo para destacar diferencias, similitudes, líneas de acción, tendencias, entre otras. Esto enriquecerá, no solo el presente trabajo sino que dotará de una nueva significación al oportunamente publicado.

En este sentido, cabe señalar que nuestro trabajo, iniciado con la publicación referida a los decretos dictados durante 2018,

\footnotetext{
15 Axel Kicillof asumió la titularidad del Poder Ejecutivo de la Provincia el 11 de diciembre de 2019.

16 Ver nuestra primera publicación: Taglianetti, Esteban F. (Director); Raffo, Mariano; Ibarra, Daniela; Deantoni Mosca, Erika; Aravena, Facundo; Simioni, María Victoria; Fernández, Guillermina; Novelli, Fernando; Grace, Jacqueline y Herrera, Daniel. Derecho Crítico (CIDERCRIT), C. de I. (2019). Análisis de los decretos emitidos por el Poder Ejecutivo de la Provincia de Buenos Aires durante el año 2018. Derechos En Acción, 13(13), 349. https://doi. org/10.24215/25251678e349
} 
ofrece un análisis de tipo estadístico -que hasta entonces no había sido realizado- que dimensiona la actividad desarrollada y que, además, permite visualizar información variada relativa a los plazos que insume cada proceso, a las áreas intervinientes y a los resultados obtenidos.

Por otra parte, nuestra labor continúa dando cuenta, en el plano práctico, del trabajo cotidiano de los órganos administrativos, ofreciendo datos e información relevantes que pueden constituirse en insumos para la evaluación de los procesos analizados, así como también para el diseño de futuras modificaciones en el marco normativo.

En lo que respecta a las tareas realizadas en el curso de la investigación, debemos mencionar, en primer lugar, la búsqueda y recopilación de la totalidad de los decretos emitidos durante el año 2019, que se encuentra disponible en los distintos sitios web oficiales de la Provincia (reservorio documental). ${ }^{17}$

A continuación, a partir de la compilación normativa efectuada y del estudio de los procesos administrativos involucrados, se llevaron a cabo las tareas de lectura y análisis de la totalidad de los decretos, de creación de una base de datos específica y de sistematización de los resultados.

En lo que respecta al examen de los actos administrativos, cabe anticipar que se estudiaron y observaron los distintos procedimientos administrativos desarrollados para su emisión; que, como se sabe, son herramientas que se aplican en las organizaciones para el cumplimiento de sus objetivos y la satisfacción de sus necesidades.

Corresponde advertir que la descripción detallada de los mencionados mecanismos administrativos se realizó en la publicación relativa a los decretos dictados durante 2018. Sin perjuicio de ello, aquellos supuestos que no fueron objeto de desarrollo en la entrega anterior o cuyo procedimiento sufrió

17 Para la búsqueda de las normas provinciales se utilizaron las siguientes páginas web oficiales: https://normas.gba.gob.ar y https://www.boletinoficial.gba.gob.ar 
un cambio significativo como consecuencia de la entrada en vigencia de alguna norma, serán expuestos en particular.

A partir de esta labor, además, se extrajeron datos relevantes para el análisis de la eficacia y eficiencia de los procesos, debido a ello, en nuestro estudio, destacamos los siguientes aspectos: el plazo que insumieron las actuaciones (tomando, como inicio, la fecha en que fueron caratulados los expedientes, conforme el sistema provincial, ${ }^{18} \mathrm{y}$, como punto de cierre, la fecha de emisión de los decretos); ${ }^{19}$ los órganos promotores y los/as funcionarios/as firmantes (obteniendo, así, información relativa a cuáles fueron las áreas de gobierno que más proyectos de decreto elevaron y qué ministerios refrendaron más actos, a los fines de determinar la participación relativa de las áreas de gobierno en la tramitación de los decretos), la intervención de los organismos de asesoramiento y control -de correspondery, las áreas sustantivas según el objeto perseguido.

Finalmente, la última tarea realizada ha sido la difusión de la investigación mediante la elaboración del presente artículo, en el cual -como se dijo- se analizaron los decretos emitidos durante el período comprendido entre el $1^{\circ}$ de enero y el $10 \mathrm{de}$ diciembre de 2019 por el Poder Ejecutivo provincial, ofreciendo una serie de gráficos y cuadros descriptivos que facilitan el acceso a la información recabada; y, además, un análisis comparativo respecto del 2018.

\section{Segunda parte: Análisis de los decretos dictados durante el 2019}

\section{II.1. Palabras introductorias}

i. Si consideramos que en el 2018 la producción de decretos de la Gobernadora saliente alcanzó los mil novecientos sesenta

\footnotetext{
18 Consulta de Expedientes: https://sistemas.gba.gov.ar/consulta/expedientes/index.php

19 No se computó, a los fines del presente, el plazo transcurrido desde el dictado del acto administrativo y su publicación en el Boletín Oficial o de notificación al interesado.
} 
y nueve (1969), y que en el 2019 dicho número disminuyó a mil ochocientos sesenta y tres (1863), el primer dato global que podemos dar es que, en el último año de gestión, el número de decretos descendió en un cinco punto treinta y ocho por ciento $(5,38 \%){ }^{20}$

En consecuencia, teniendo en cuenta las cifras indicadas, y que en el período en análisis del año 2019 hubo doscientos treinta $(\mathbf{2 3 0})^{21}$ días laborables, el promedio diario fue de ocho (8) decretos.

ii. A continuación mostramos la distribución de los decretos dictados por materia, indicando cantidades y proporción sobre el total. También señalaremos la cantidad de decretos emitidos por mes.

20 Para completar la información diremos que, en el 2015, el ex Gobernador Daniel Scioli dictó un total de dos mil seiscientos veintitrés (2.623) decretos y que María Eugenia Vidal suscribió un total de noventa y ocho (98). Dando un total de dos mil setecientos veintiuno (2721). El elevado número entendemos responde a las siguientes razones: 1) menor delegación de funciones en los/as ministros/as; 2) ser el último año de gobierno de Scioli; 3) Ser los primeros veintiún días de Gobierno de Vidal lo que implicó la modificación de las estructuras administrativas y la designación de los/as nuevos/as funcionarios/as.

En el 2016, se dictaron dos mil ciento setenta y siete (2177) decretos, el mayor número de decretos dictados por Vidal durante su gestión. Ello podría deberse, como se dijo ut supra, al dictado del Decreto $N^{\circ} 272 / 17 \mathrm{E}$, ampliando las materias delegadas en los titulares de los distintos organismos de la órbita del Poder Ejecutivo.

21 A los fines de determinar la cantidad de días laborables hasta el 10 de diciembre de 2019, fin de la gestión de María Eugenia Vidal, se ponderaron las siguientes cuestiones, a saber:

1) Ley $N^{0} 27.399$ (Norma de establecimiento de feriados nacionales y días no laborables en todo el territorio nacional), establece lo siguiente: a. Feriados nacionales inamovibles: ocho (8) días feriados nacionales que no cayeron en días sábados o domingos; b. Feriados nacionales trasladables: uno (1) fue trasladado y uno (1) no lo fue que cayó el día lunes 17/6, y c. Días no laborables: uno (1) jueves Santo;

2) Días no laborables con fines turísticos, contemplados en el artículo $7^{\circ}$ de la Ley № 27.399 (denominados "Feriados puentes"): tres (3);

3) Día del trabajador del Estado - Ley provincial No 14.600 (27/6/19): uno (1):

4) Se computó el 19 de noviembre de 2019, aniversario de la fundación de la Ciudad de La Plata.

En consecuencia, con el objetivo de determinar los días laborables de la Secretaría referenciada, debemos afirmar que éstos ascienden al número de doscientos treinta (230) días. 


\begin{tabular}{|c|c|c|c|}
\hline MATERIA & \# Decretos 2018 & \# Decretos 2019 & Variación \\
\hline Personal & 1373 & 1484 & $8,08 \%$ \\
\hline Poder Judicial & 190 & 122 & $-35,79 \%$ \\
\hline Procuracion & 127 & 76 & $-40,16 \%$ \\
\hline Politica Salarial & 25 & 37 & $48,00 \%$ \\
\hline No Parametrizados & 41 & 35 & $-14,63 \%$ \\
\hline Convenios & 62 & 28 & $-54,84 \%$ \\
\hline Reglamentario & 21 & 17 & $-19,05 \%$ \\
\hline Contrataciones & 11 & 16 & $45,45 \%$ \\
\hline Recurso Interpuesto & 5 & 8 & $60,00 \%$ \\
\hline Estructuras & 24 & 8 & $-66,67 \%$ \\
\hline Convalida Ordenanza & 22 & 6 & $-72,73 \%$ \\
\hline Rectificatorio & 7 & 5 & $-28,57 \%$ \\
\hline Regimen Disciplinario & 4 & 5 & $25,00 \%$ \\
\hline Delegaciones & 4 & 4 & $0,00 \%$ \\
\hline Parques Industriales & 3 & 4 & $33,33 \%$ \\
\hline Promulgatorio & 16 & 3 & $-81,25 \%$ \\
\hline Subsidios & 13 & 2 & $-84,62 \%$ \\
\hline Legitimo Abono & 2 & 1 & $-50,00 \%$ \\
\hline Tarifa & 2 & 1 & $-50,00 \%$ \\
\hline Despacho & 2 & 1 & $-50,00 \%$ \\
\hline Emergencia Agropecuaria & 5 & 0 & $-100,00 \%$ \\
\hline Bienes & 4 & 0 & D. $-100,00 \%$ \\
\hline Veto Parcial & 2 & 0 & $-100,00 \%$ \\
\hline Caja de Policias & 1 & 0 & $-100,00 \%$ \\
\hline Honorarios Profesionales & 1 & 0 & $\sqrt{4}-100,00 \%$ \\
\hline Veto & 1 & 0 & D $-100,00 \%$ \\
\hline Viaje al Exterior & 1 & 0 & $\sqrt{3}-100,00 \%$ \\
\hline Total & 1969 & 1863 & $-5,38 \%$ \\
\hline
\end{tabular}

Ilustración 1. Total de decretos por materia. Fuente: elaboración propia 


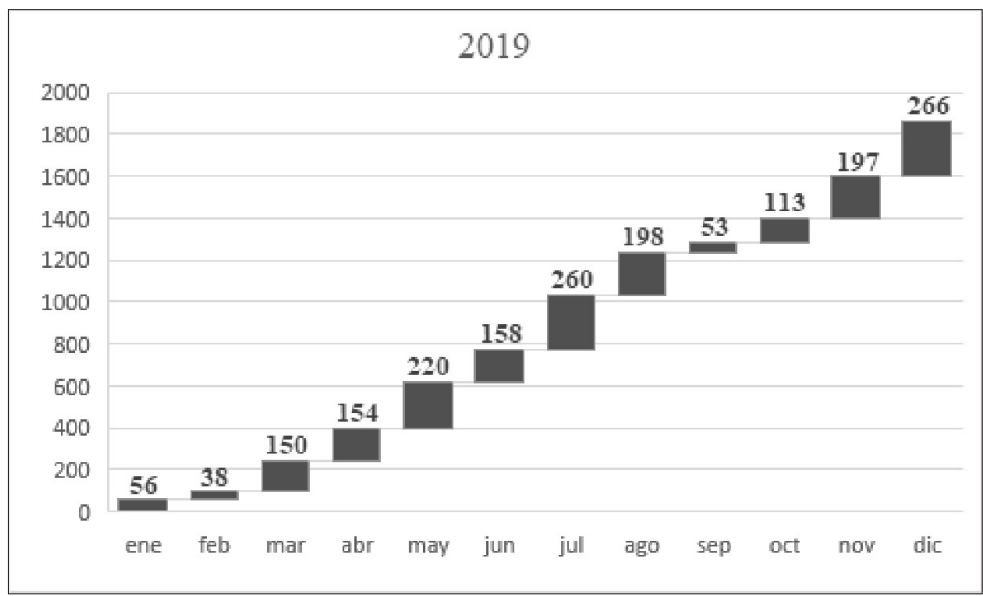

Ilustración 2. Total de decretos por mes. Fuente: elaboración propia

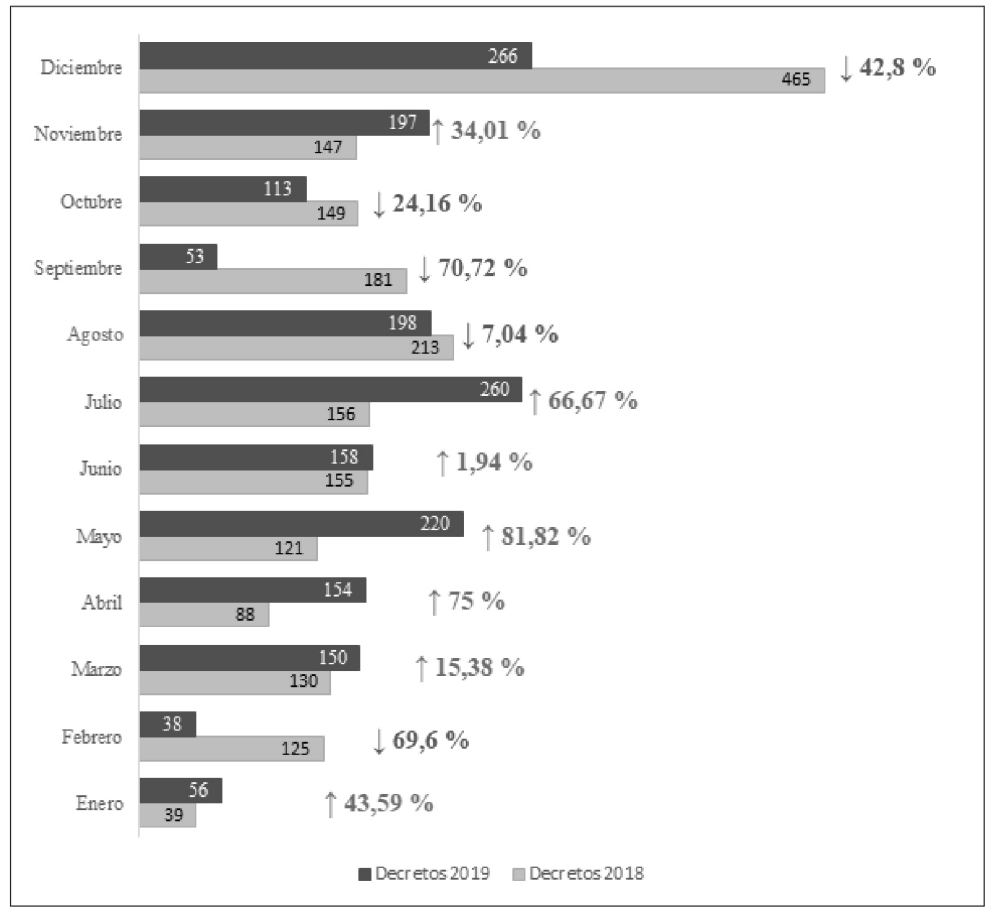

llustración 3. Total de decretos por mes - Comparado con el año anterior.

Fuente: elaboración propia 
iii. Respecto al promedio de días de tramitación de las actuaciones hasta llegar a la máxima autoridad (Gobernadora), debemos indicar que éstos varían según el soporte en el que se gestionan. En efecto, del análisis efectuado podemos aseverar que los expedientes electrónicos lucen más eficaces y eficientes que los de soporte papel. Verdad que puede parecer obvia, pero que ahora contamos con la información para avalarla.

En un análisis lineal, en cuanto a los días de demora, la diferencia entre ambos asciende a seiscientos cuarenta y seis (646) días.

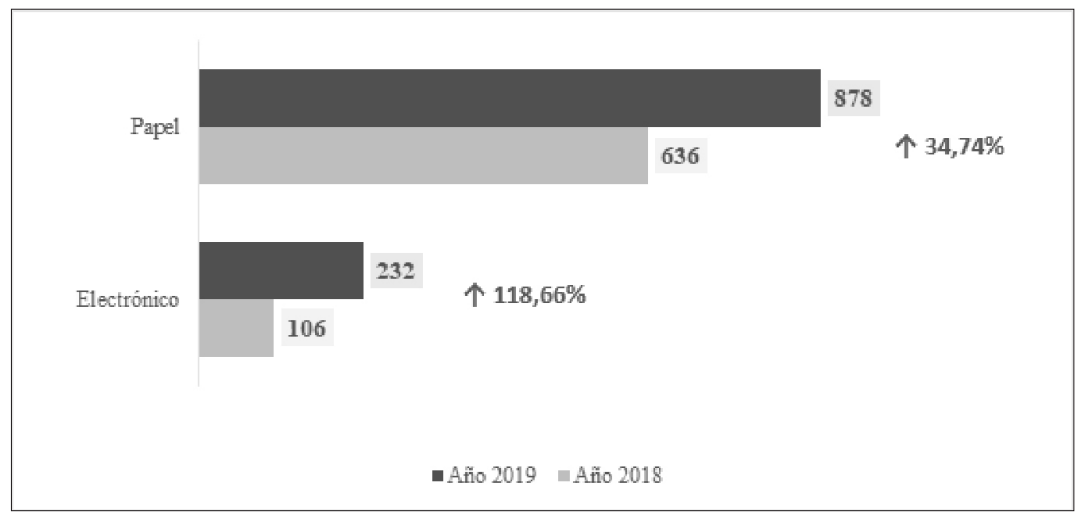

llustración 4. Demora promedio de tramitación, comparado con el año anterior. Fuente: elaboración propia

No obstante, es pertinente aclarar que el paralelismo así planteado castiga al expediente papel, toda vez que existen actuaciones que registran trámites anteriores, a cuyos datos no se pudo acceder, en donde el inicio fue de meses y hasta años previos al primer expediente electrónico. Ahora bien, analizando la diferencia en días, pero reduciendo la muestra a aquellos expedientes papel iniciados a partir del 12 de julio 2017 -fecha del expediente electrónico más antiguo-, la brecha se reduce a ciento noventa y cuatro (194) días, diferencia igualmente significativa. 


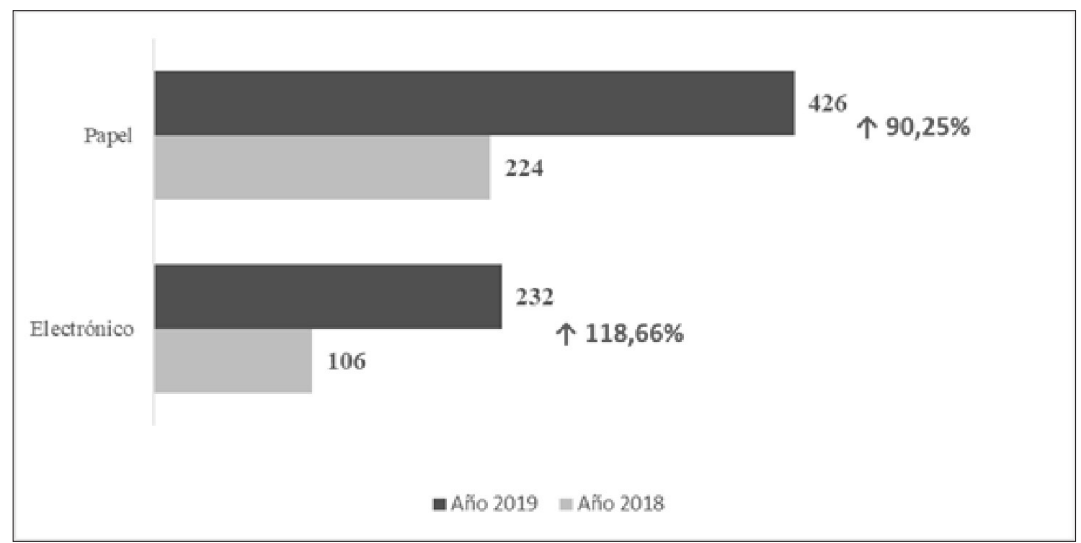

Ilustración 5. Demora promedio de tramitación, período restringido, comparado con el año anterior. Fuente: elaboración propia

iv. Finalmente, cerraremos estas palabras introductorias advirtiendo que, en aquellos casos en que se señalan las áreas intervinientes en los distintos procedimientos administrativos, éstas son consignadas conforme la denominación vigente al momento del dictado del decreto analizado.

\section{II.2. Análisis en particular de los decretos según su temática}

II.2.1. Decretos referidos al personal de la Administración Pública

i) En el anterior trabajo de investigación se realizó el estudio de los decretos dictados durante 2018 referidos al personal de la Administración Pública. ${ }^{22}$ En aquella oportunidad habíamos contabilizado mil trescientos veinticuatro (1.324) decretos referidos a personal y señalamos que representaban el sesenta y siete con veinticuatro por ciento $(\mathbf{6 7 , 2 4 \% )}$ respecto del total

22 Expresión que pretende incluir diversas realidades, a saber: personal de planta permanente (con y sin estabilidad), personal de planta temporaria (personal de gabinete, secretarios privados, contratado y transitorio), locaciones de servicios en los términos de la ley de emergencia y locación de obra. 
de mil novecientos sesenta y nueve (1.969) decretos suscriptos en 2018.

En esta ocasión, como primera observación, advertimos que la tendencia de mayor volumen de actos administrativos dictados en materia de personal se mantiene en 2019: mil cuatrocientos ochenta y cuatro (1.484) decretos, sobre un total de mil ochocientos sesenta y tres (1.863). Esto es, el setenta y nueve con sesenta y cinco por ciento $(\mathbf{7 9}, \mathbf{6 5} \%)$ de los actos.

Tampoco resulta llamativo -dada la experiencia anteriorque, por ejemplo, tomando como subgrupo las designaciones en las plantas permanente y temporaria, que se escoge intencionalmente dado que son mil setenta y cuatro (1.074) decretos, los plazos promedio de gestión de las actuaciones hayan insumido seiscientos treinta y un (631) días. En 2018, el promedio de este subgrupo fue de quinientos setenta (570) días. En ambos casos, queda evidenciada que las labores referidas a la materia resultan ser de aquellas que más tiempo y personal insumen para su concreción. Sin embargo, se aprecia un cambio en la cultura organizacional de la Administración que, con relativa velocidad, va virando del expediente papel al electrónico, con una notable reducción de tiempos.

En el siguiente gráfico apuntamos los promedios en días corridos de acuerdo al tipo de trámite y con referencia a la gestión electrónica ${ }^{23}$ y a la tradicional en papel ${ }^{24}$.

\footnotetext{
23 El Sistema de Gestión Documental Electrónica Buenos Aires es la plataforma informática que permite la gestión digital de todos los trámites de la Administración Central y Organismos Descentralizados de la provincia de Buenos Aires. La administración general de GDEBA y su ejecución están a cargo de la Dirección Provincial de Mejora Administrativa, perteneciente a la Subsecretaría de Gobierno Digital de Jefatura de Gabinete de Ministros. Consta de diferentes módulos de formación, de acuerdo a las instancias de intervención: Escritorio Único, Comunicaciones Oficiales, Generador Electrónico de Documentos Oficiales y Expediente Electrónico. Su implementación fue aprobada por Decreto N 1018/16, reglamentario de la Ley $\mathrm{N}^{0} 14.828$.

24 En rigor, la mayoría de estos expedientes son mixtos, ya que luego de iniciar en soporte papel, en su derrotero, se le incorporan impresiones de documentos generados en el sistema GDEBA).
} 


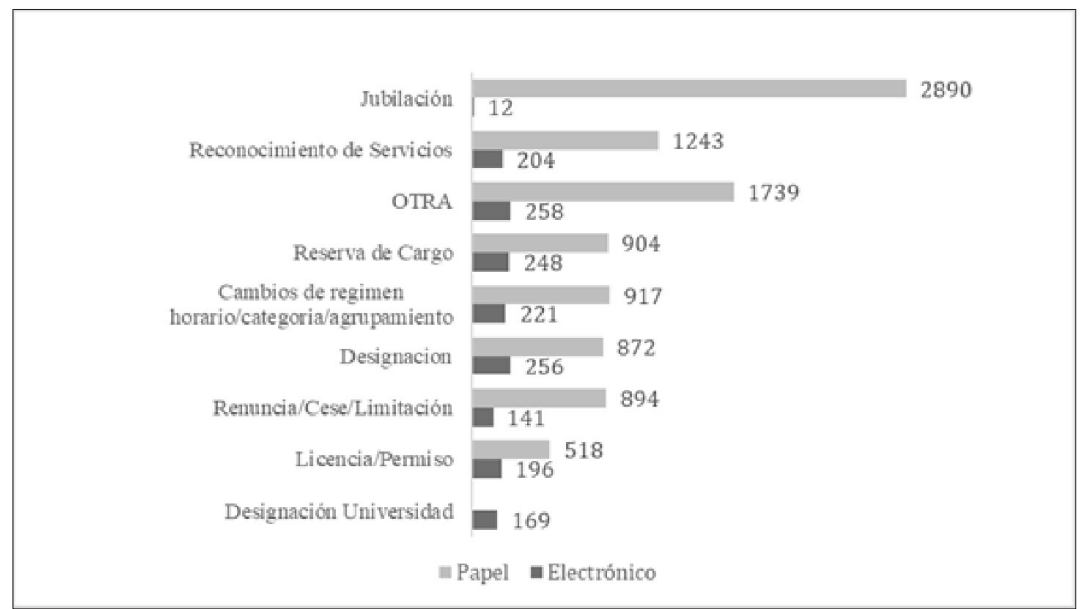

Ilustración 6. Demora promedio por tipo de gestión y por tipo de tramitación.

Fuente: elaboración propia

A continuación, vinculamos los actos a las jurisdicciones y a los distintos organismos provinciales promotores de su dictado. Como se desprende del cuadro, también guardan cierta relación de paridad los años que se comparan:

\begin{tabular}{|c|c|c|c|c|}
\hline Órgano Promotor & 2018 & 2019 & \multicolumn{2}{|c|}{ Variación } \\
\hline Ministerio de Salud & 885 & 919 & ๑ & $4 \%$ \\
\hline Ministerio de Gobierno & 13 & 81 & A & $523 \%$ \\
\hline IOMA & 56 & 52 & $\sqrt{3}$ & $-7 \%$ \\
\hline Sin promotor * & 3 & 50 & A & $1567 \%$ \\
\hline Jefatura de Gabinete de Ministros & 20 & 33 & ๑ & $65 \%$ \\
\hline OPDS & 44 & 33 & $\sqrt{b}$ & $-25 \%$ \\
\hline otro & 24 & 29 & 禅 & $21 \%$ \\
\hline Loteria y Casinos & 24 & 27 & A & $13 \%$ \\
\hline Patronato de liberados & 20 & 23 & ๑ & $15 \%$ \\
\hline Instituto de Prevision Social & 15 & 22 & A & $47 \%$ \\
\hline Ministerio de Ciencia Tecnologia e Innovacion & 14 & 20 & 个 & $43 \%$ \\
\hline Tribunal de Cuentas & 7 & 20 & A & $186 \%$ \\
\hline Secretaria Legal y Tecrica & 7 & 17 & 周 & $143 \%$ \\
\hline CIC & 15 & 16 & 4 & $7 \%$ \\
\hline Ministerio de Produccion & 16 & 15 & $\sqrt{3}$ & $-6 \%$ \\
\hline Ministerio de Economia & 8 & 14 & A & $75 \%$ \\
\hline Ministerio de Infraestructura y Servicios Publico & 37 & 13 & $\sqrt{3}$ & $-65 \%$ \\
\hline
\end{tabular}




\begin{tabular}{|c|c|c|c|c|}
\hline Ministerio de Trabajo & 11 & 10 & $\sqrt{3}$ & $-9 \%$ \\
\hline Asesoria General de Gobierno & 10 & 11 & 穴 & $10 \%$ \\
\hline Instituto de la Vivienda & 9 & 10 & दि & $11 \%$ \\
\hline Contaduria General de la Provincia & 4 & 9 & 个 & $125 \%$ \\
\hline OPISU & 2 & 9 & 4 & $350 \%$ \\
\hline Autoridad del Agua & 23 & 8 & $\sqrt{3}$ & $-65 \%$ \\
\hline Ministerio de Desarrollo Social & 7 & 8 & 个 & $14 \%$ \\
\hline Fiscalia de Estado & 12 & 7 & $\sqrt{b}$ & $-42 \%$ \\
\hline Tesoreria General & 6 & 5 & $\sqrt{4}$ & $-17 \%$ \\
\hline Ministerio de Justicia & 4 & 5 & T & $25 \%$ \\
\hline Secretaria General & 1 & 5 & P & $400 \%$ \\
\hline Ministerio de Seguridad & 6 & 3 & $\sqrt{3}$ & $-50 \%$ \\
\hline Secretaria Derechos Humanos & 5 & 3 & $\sqrt{3}$ & $-40 \%$ \\
\hline Ministerio de Gestion Cultural & 5 & 2 & $\sqrt{3}$ & $-60 \%$ \\
\hline Secretaria de Medios & 3 & 2 & $\sqrt{3}$ & $-33 \%$ \\
\hline Direccion Provincial de Vialidad & 4 & 1 & $\sqrt{y}$ & $-75 \%$ \\
\hline ARBA & 2 & 1 & $\sqrt{3}$ & $-50 \%$ \\
\hline Ministerio de Agroindustria & 1 & 1 & $\sqrt{3}$ & $0 \%$ \\
\hline Ministerio de Asuntos Publicos & 1 & 0 & $\sqrt{3}$ & $-100 \%$ \\
\hline Total general & 1324 & 1484 & 1 & $12 \%$ \\
\hline
\end{tabular}

Ilustración 7. Cantidad de Decretos de personal, apertura por Órgano Promotor, comparado con el año anterior. Fuente: elaboración propia $\left({ }^{*}\right)^{25}$

En los dos gráficos siguientes -dos formas expositivas distintas, pero con la misma información- hacemos un desagregado por ítems, con una escala decreciente según la cantidad de decretos para cada uno de ellos, a la vez que se compara con la cantidad de actos del año anterior y el porcentaje de variación:

25 La categoría "Sin promotor" hace referencia a los decretos dictados sin manifestar en el visto (la parte enunciativa del acto) el número de expediente, cuya composición -sea mediante siglas si es electrónico o código numérico si tiene formato papel- indica el organismo generador.

La composición es la siguiente: cuarenta y siete (47) son renuncias de funcionarios/as varios/as, uno (1) es renuncia a sendos cargos de representantes del Poder Ejecutivo ante el Consejo de la Magistratura (Decreto No 1815/19), y dos (2) son designaciones: Secretario Legal y Técnico (Decreto No 130/19 y Ministro de Economía (Decreto N 1174/19). 


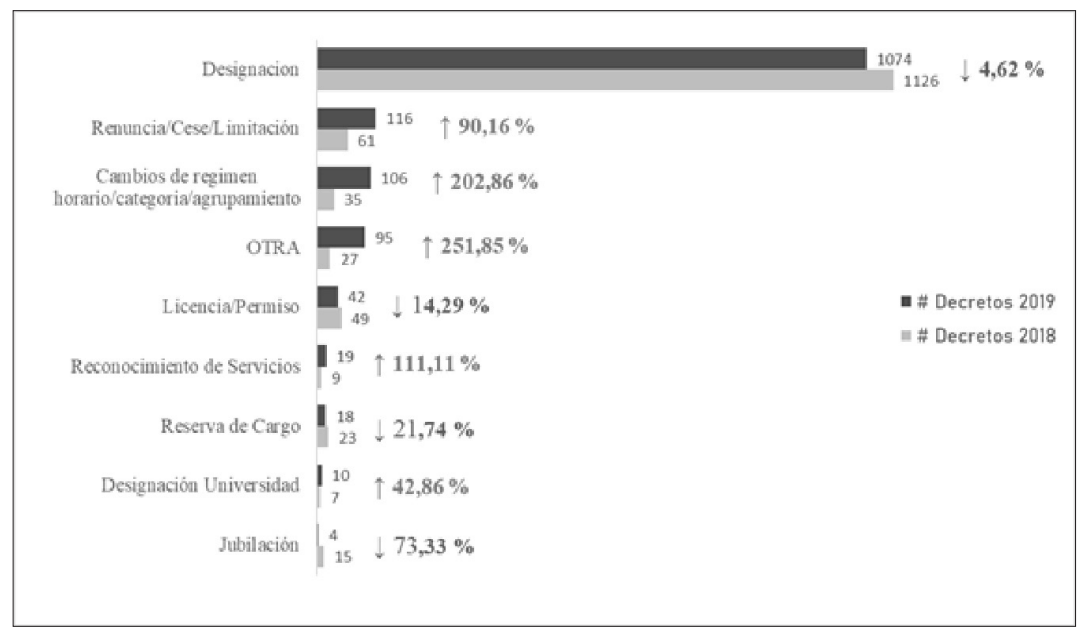

llustración 8. Cantidad de Decretos de personal, apertura por tipo de gestión, comparado con el año anterior. Fuente: elaboración propia

\begin{tabular}{|c|c|c|c|c|}
\hline Items & Decretos 2018 & Decretos 2019 & \multicolumn{2}{|c|}{ Variación } \\
\hline Designación & 1126 & 1074 & 4 & $-4.62 \%$ \\
\hline Remuncia/Cese/Limitación & 61 & 116 & A & $90.16 \%$ \\
\hline Cambios de régimen hora rio/ca tegoria/agrupamiento & 35 & 106 & A & $202,86 \%$ \\
\hline OTRA & 27 & 95 & ק & $251,85 \%$ \\
\hline Licencia/Permiso & 49 & 42 & 4 & $-14,29 \%$ \\
\hline Reconocimiento de Servicios & 9 & 19 & $\widehat{A}$ & $111,11 \%$ \\
\hline Reserva de Cargo & 23 & 18 & 4 & $-21,74 \%$ \\
\hline Designación Universidad & 7 & 10 & T & $42,86 \%$ \\
\hline Iubilación & 15 & 4 & 4 & $-7333 \%$ \\
\hline Total & 1352 & 1484 & $\mathbf{T}$ & $9,76 \%$ \\
\hline
\end{tabular}

Ilustración 9. Cantidad de Decretos de personal, apertura por tipo de gestión, comparado con el año anterior. Fuente: elaboración propia

A partir de estos datos más globales, y siguiendo el método empleado en la investigación anterior, pasamos a exponer los relevados según cada ítem, siempre cotejando el resultado obtenido con lo sucedido en 2018 :

\section{a. Designaciones:}

Se verificaron mil setenta y cuatro (1.074) decretos de designación de personal, contra mil ciento veintiséis (1.126) en 2018. 
Ahora, pasamos a descomponer estos números según el tipo de planta (temporaria y permanente), con un residual que obedece a regímenes especiales fuera de los mecanismos previstos en la Ley $\mathrm{N}^{\circ} 10.430$ :

\begin{tabular}{|l|r|r|r|}
\hline \multicolumn{1}{|c}{ Tipo de Gestión } & Decretos $\mathbf{2 0 1 8}$ & Decretos 2019 & Variación \\
\hline PLANTA TEMPORARIA & 622 & 622 & $0 \%$ \\
\hline Personal Transitorio & 563 & 593 & $5 \%$ \\
\hline Personal de Gabinete & 59 & 29 & $-51 \%$ \\
\hline PLANTA PERMANENTE & 501 & 429 & $-14 \%$ \\
\hline Funcionario & 169 & 126 & $-25 \%$ \\
\hline Personal con Estabilidad & 332 & 303 & $-9 \%$ \\
\hline OTRO & 3 & 23 & $667 \%$ \\
\hline $\begin{array}{l}\text { Designaciones, renuncias, } \\
\text { comisiones, consejos, etc. }\end{array}$ & 3 & 23 & $667 \%$ \\
\hline Total general & $\mathbf{1 1 2 6}$ & $\mathbf{1 0 7 4}$ & $\mathbf{- 5 \%}$ \\
\hline
\end{tabular}

Ilustración 10. Cantidad de Decretos de Designación de personal, apertura por régimen, comparado con el año anterior. Fuente: elaboración propia

Vemos que en 2019 se siguió la tendencia de 2018, al dictarse una cantidad similar de decretos de designaciones en el Poder Ejecutivo (o en representación del mismo, en el caso de ciertos organismos o consejos interjurisdiccionales).

En cuanto a la cantidad de personas involucradas en las designaciones, fueron tres mil ciento veinte $\left(\mathbf{3 . 1 2 0}^{26}\right)$ : mil doscientos veintidós (1.222) agentes de género masculino (39,16\%) y mil ochocientos noventa y ocho (1.898) de género femenino $(\mathbf{6 0 , 8 3 \%})$. De las cuales, catorce (14) fueron incorporadas en el marco de la Ley $\mathrm{N}^{\mathrm{o}} 10.592$ (régimen jurídico básico e integral para las personas con discapacidad), a través de siete (7) decretos. Por último, se contabilizan -dentro del

26 Cabe aclarar que el cotejo es entre la cantidad de personas involucradas en los decretos dictados entre ambos años, y no se refiere a la variación de los planteles básicos (entendidos como la dotación de personal medida en términos cuantitativos y cualitativos para la consecución de las misiones y para el ejercicio de las funciones inherentes a la Administración pública, artículo 139, Ley N²10.430). 
total de señalado- ciento setenta y cuatro (174) funcionarios/as y cuarenta y un (41) personas designadas como personal de gabinete-. Entre los años comparados se vuelve a repetir la mayor designación de personas de género femenino entre los planteles de categorías iniciales, pero la situación se revierte en los niveles de funcionarios/as.

En el trabajo publicado por este equipo en diciembre de 2019, habíamos propuesto como balance que las tendencias con base en la evidencia y los datos disponibles, demostraban la naturaleza generalizada del trato desigual respecto del género femenino.

En 2018 se designaron tres mil trescientas veintisiete (3.327) personas, doce (12) fueron incorporadas bajo el régimen de la Ley $\mathrm{N}^{\circ}$ 10.592, a través de cinco (5) Decretos. Los restantes datos correspondientes a aquel año, a fin de no extendernos con su transcripción, se citan en el siguiente gráfico:

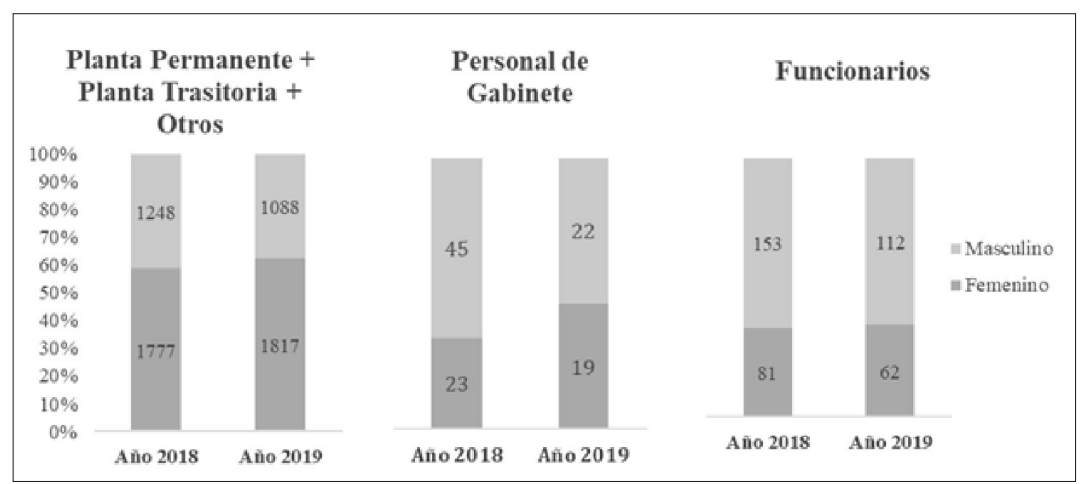

llustración 11. Cantidad de personas designadas, apertura por género, comparado con el año anterior. Fuente: elaboración propia

Respecto al rango etario de los/as funcionarios/as y del personal de gabinete designados/as, agregamos el siguiente recuento comparativo 2018-2019: 


\begin{tabular}{|c|c|c|c|c|c|c|c|c|}
\hline \multirow{2}{*}{ Década } & \multicolumn{4}{|c|}{ Funcionarios } & \multicolumn{4}{|c|}{ Personal de Gabinete } \\
\hline & 2018 & 2019 & & ción & 2018 & 2019 & & iación \\
\hline 40 & 3 & 4 & 14 & $33 \%$ & 1 & 1 & 14 & $0 \%$ \\
\hline 150 & 33 & 21 & $\sqrt{4}$ & $-36 \%$ & 6 & 3 & $\sqrt{4}$ & $-50 \%$ \\
\hline '60 & 62 & 37 & $\sqrt{1}$ & $-40 \%$ & 7 & 8 & 14 & $14 \%$ \\
\hline '70 & 72 & 47 & $\sqrt{3}$ & $-35 \%$ & 15 & 13 & $\sqrt{3}$ & $-13 \%$ \\
\hline '80 & 58 & 28 & $\sqrt{4}$ & $-52 \%$ & 30 & 10 & $\sqrt{4}$ & $-67 \%$ \\
\hline 90 & 6 & 4 & $\sqrt{4}$ & $-33 \%$ & 9 & 2 & $\sqrt{3}$ & $-78 \%$ \\
\hline Total & 234 & 141 & $\sqrt{2}$ & $-40 \%$ & 68 & 37 & 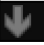 & $-46 \%$ \\
\hline
\end{tabular}

Ilustración 12. Cantidad de Funcionarios y Personal de Gabinete designados, apertura por rango etario, comparado con el año anterior. Fuente: elaboración propia

Seguidamente, por relevancia -medida por la cantidad de decretos- procedemos a describir las designaciones en la órbita del Ministerio de Salud.

Se dictaron ochocientos setenta y tres (873) decretos (es el $\mathbf{8 1 , 2 8 \%}$ de los decretos de designaciones), nombrando a mil novecientas cuarenta y nueve (1.949) personas, siendo seiscientas cincuenta (650) de género masculino (33,35\%) y mil doscientos noventa y nueve (1.299) de género femenino (66,65\%). De los cuales:

- cincuenta (50) son funcionarios/as: veintiséis (26) de género masculino (52\%) y veinticuatro (24) de género femenino (48\%).

- seiscientos once (611) de Planta Permanente: doscientos doce (212) de género masculino $(\mathbf{3 4 , 7 0 \% )}$ y trescientos noventa y nueve (399) de género femenino (65,3\%).

- mil doscientos ochenta y ocho (1.288) de Planta Temporaria: cuatrocientos doce (412) de género masculino $(31,99 \%)$ y ochocientos setenta y seis (876) de género femenino $(\mathbf{6 8 , 0 1 \%})$.

Con relación a 2018, existe la siguiente variación: 


\begin{tabular}{|c|c|c|c|c|c|c|c|}
\hline Tipo de Gestión & \multicolumn{3}{|c|}{ Femenino } & \multicolumn{3}{c|}{ Masculino } \\
\hline Personal Transitorio & $\mathbf{2 0 1 8}$ & $\mathbf{2 0 1 9}$ & $\mathbf{8 7 6}$ & Variación & $\mathbf{2 0 1 8}$ & $\mathbf{2 0 1 9}$ & Variación \\
\hline Personal con Estabilidad & 580 & 399 & $-31 \%$ & 178 & 412 & $131 \%$ \\
\hline Funcionario & 21 & 24 & $14 \%$ & 16 & 212 & $-42 \%$ \\
\hline Total general & $\mathbf{9 9 4}$ & $\mathbf{1 2 9 9}$ & $\mathbf{4}$ & $\mathbf{3 1} \%$ & $\mathbf{5 5 8}$ & $\mathbf{6 5 0}$ & $\mathbf{1 6} \%$ \\
\hline
\end{tabular}

Ilustración 13. Cantidad de personal designado en el Ministerio de Salud, apertura por régimen y género, comparado con el año anterior. Fuente: elaboración propia

b. Designaciones en universidades provinciales:

A través de diez (10) decretos se procedió a la designación de docentes ${ }^{27}$ en las Universidades Provinciales de Ezeiza y del Sudoeste, contra siete (7) decretos en 2018.

\section{c. Ceses por renuncia o limitación:}

En el 2019 se dictaron ciento dieciséis (116) decretos de cese de agentes (61 el año anterior), ${ }^{28}$ según el siguiente detalle comparativo:

\begin{tabular}{|c|c|c|c|c|c|c|c|}
\hline \multirow{2}{*}{ Tipo de Gestión } & \multicolumn{3}{|c|}{ M ujeres } & \multicolumn{4}{|c|}{ Hombres } \\
\hline & 2018 & 2019 & Variación & 2018 & 2019 & & iación \\
\hline PL ANTA TEMPOR ARIA & 7 & 30 & $\triangle \quad 329 \%$ & 6 & 56 & $\triangle$ & $833 \%$ \\
\hline Personal Transitorio & 1 & 1 & $0 \%$ & - & - & & \\
\hline Personal de Gabinete & 6 & 29 & $\triangle \quad 383 \%$ & 6 & 56 & $\triangle$ & $833 \%$ \\
\hline PLANTA PERMANENTE & 16 & 56 & $\triangle \quad 250 \%$ & 47 & 143 & $\therefore$ & $204 \%$ \\
\hline Personal con Estabilidad & 1 & 15 & $\triangle 1400 \%$ & 4 & 19 & $\Delta$ & $375 \%$ \\
\hline Funcionario & 15 & 41 & $\therefore \quad 173 \%$ & 43 & 124 & $\Delta$ & $188 \%$ \\
\hline OTRO & 1 & 1 & $0 \%$ & 2 & 11 & $\triangle$ & $450 \%$ \\
\hline $\begin{array}{l}\text { De signaciones, remuncias, } \\
\text { comisiones, consejos, etc }\end{array}$ & 1 & 1 & $0 \%$ & 2 & 11 & $\triangle$ & $450 \%$ \\
\hline Total general & 24 & 87 & A. $263 \%$ & 55 & 210 & A & $282 \%$ \\
\hline
\end{tabular}

Ilustración 14. Cantidad de personal cesante, apertura por régimen y género, comparado con el año anterior. Fuente: elaboración propia

27 Por Decreto $N^{0} 1800 / 19$ se designaron 25 agentes como personal no docente en la Universidad Provincial de Ezeiza (7 de género masculino y 18 de género femenino). Por Decreto $N^{0} 1449 / 19$ se designó 1 agente de género femenino como personal no docente en la Universidad Provincial de Ezeiza.

28 Una posible explicación al incremento de decretos referidos al cese de agentes, la podemos encontrar en la aceptación de las renuncias de los/as funcionarios/as del gobierno saliente, dado el cambio de gestión operado el 10 de diciembre del año analizado. 


\section{d. Ceses por jubilación:}

Se dictaron cuatro (4) decretos para disponer el cese a los efectos de acogerse a los beneficios jubilatorios de cinco (5) agentes, cuatro (4) personas de género masculino y una (1) de género femenino; poco menos que los quince (15) decretos de 2018.

e. Cambios de régimen/agrupamiento/categoría:

A través de ciento seis (106) decretos se dispusieron cambios de régimen, de agrupamiento y categoría, contemplando en algunos casos un número no definido de agentes. Se evidencia una mayor cantidad de casos resueltos respecto del período 2018, que tuvo treinta y cinco (35) decretos.

\section{f. Reservas de cargo:}

Se formularon reservas de cargo de revista a través de dieciocho (18) decretos, ejerciendo este derecho diez (10) personas de género masculino y ocho (8) de género femenino. En 2018 hubo veintitrés (23) decretos.

\section{g. Licencias/permisos:}

Durante el período analizado se dictaron cuarenta y dos (42) decretos que otorgaron licencias y permisos (21 decretos en 2018), de los cuales veintidós (22) fueron concedidos con goce de haberes y veinte (20) sin goce de haberes. Resultaron beneficiarias cuarenta y dos (42) personas: trece (13) de género masculino y veintinueve (29) de género femenino. Cuatro (4) fueron licencias políticas, concedidas de conformidad con el artículo 58 de la Ley No 10.430 (T.O. por Decreto $N^{\circ} 1869 / 96$ ) y su modificatoria Ley $\mathrm{N}^{\mathrm{o}} 13.967$.

\section{h. Reconocimientos de servicios:}

Se dictaron diecinueve (19) decretos con motivo de distintas solicitudes de reconocimientos (de servicios, recategorización y pago de diferencias salariales), rechazándose diez (10) de las peticiones. 


\section{i. Otros:}

Aquí, residualmente, incluimos los noventa y cinco (95) decretos que no cuadran en ninguna de las clasificaciones anteriores. En general, se refieren a ordenamientos internos del personal de la Administración (establecen fechas de inicio de actividades, traslados, reincorporaciones, tienen por incorporados/as agentes en el régimen de la Ley $\mathrm{N}^{\circ} 10.592$ cuando no se hicieron oportunamente, otorgan pases a prestar servicios en comisión, convalidan actos dictados por funcionarios/as sin competencia, otorgan subsidios por fallecimiento, etc.).

\section{II.2.2. Decretos relativos al régimen disciplinario de la Administración Pública}

Previo referir los decretos dictados sobre la temática en el año 2019, recordaremos que el régimen disciplinario en la Administración Pública provincial está regulado en la Ley $\mathrm{N}^{\circ} 10.430$ y su reglamentación, a partir del artículo 80. Asimismo, distintos regímenes especiales prevén el instituto, tales como el Estatuto Docente (Ley $\mathrm{N}^{\circ}$ 10.579), el régimen del Personal de las Policías de la Provincia de Buenos Aires (Ley No 13.201), del Servicio Penitenciario (Decreto Ley $N^{\circ}$ 9578/80). Otros reenvían al régimen general de la Ley $\mathrm{N}^{\circ} 10.430$, por ejemplo, la Carrera Profesional Hospitalaria (Ley $\mathrm{N}^{\mathrm{o}} 10.471$ ) y Actividades Artísticas (Ley $\mathrm{N}^{\mathrm{o}}$ 12.268).

Restan situaciones poco frecuentes, como es la referida al personal que se desempeña en los Casinos. Al respecto, por Ley $\mathrm{N}^{\mathrm{o}} 11.536$, la provincia de Buenos Aires reasume la administración y explotación de los Casinos autorizados en su jurisdicción, acordándose que el Instituto Provincial de Lotería y Casinos en su calidad de empleador, tendrá los derechos y obligaciones emergentes del Régimen Jurídico Básico de la Función Pública -Ley $\mathrm{N}^{\mathrm{0}} 22.140^{29}$ - y toda la normativa que reglaba

\footnotetext{
29 Nota Infoleg: La presente Ley fue derogada por el art. $4^{0}$ de la Ley N 25.164 B.0. 08/10/1999. No obstante, sigue rigiendo la relación laboral del personal hasta que se firme
} 
las modalidades laborales del personal compresivo del régimen disciplinario y sumarial aprobado por el Decreto Nacional $\mathrm{N}^{\mathrm{o}} 1798 / 80$, actual Decreto Nacional No 467/99, modificado por Decreto $N^{\circ} 1012 / 2012$.

En este marco, el Decreto No 4406/96 dispone que serán de aplicación las normas de procedimiento emanadas del Reglamento de Investigaciones Nacional aprobado por el referido Decreto $N^{\circ} 1798 / 80$, en toda actuación sumarial que involucre al personal de Casinos. Por otra parte, faculta al Directorio del Instituto Provincial de Lotería y Casinos a ordenar la instrucción de dichos sumarios, los que serán sustanciados en el Departamento Legales del área Casinos. Recibidas las actuaciones o, en su caso, producida la audiencia oral y pública, el Instituto dictará resolución. En caso de sanciones expulsivas, la medida será aplicada "ad-referendum" del Poder Ejecutivo.

Por último, para completar el escenario de actuación, cabe señalar que por Decreto $\mathrm{N}^{\circ} 272 / 17 \mathrm{E}^{30}$ en su versión original vigente en 2019, el Poder Ejecutivo delega en los/as Ministros y Ministras, Secretarios y Secretarias, titulares de los Organismos de la Constitución y Asesor/a General de Gobierno la facultad de disponer: a) la conversión de la sanción expulsiva de exoneración en cesantía, b) rehabilitaciones, c) prorrogar los plazos para la conclusión de sumarios administrativos, ampliar suspensiones preventivas y disponibilidades relativas y d) suspender la aplicación de sanciones expulsivas cuando medie recurso contra ellas (artículo $3^{\circ}$ incisos 5, 6, 7 y 8, respectivamente).

Con este breve repaso, pasamos al análisis de los actos administrativos dictados en la materia durante 2019.

Como primer señalamiento, observamos que se dictaron cinco (5) decretos, bajo los $\mathrm{N}^{\circ} 220 / 19$, $\mathrm{N}^{\circ} 1702 / 19$, $\mathrm{N}^{\circ} 1703 / 19$, $\mathrm{N}^{\mathrm{o}} 1704 / 19$ y No $1801 / 19$.

el convenio colectivo de trabajo, o se dicte un nuevo ordenamiento legal que reemplace al anterior (http://www.infoleg.gob.ar/).

30 Actualmente rige con las modificaciones introducidas por los Decretos $N^{0}$ 99/2020, $N^{0} 543 / 2020$ y N ${ }^{0} 610 / 2020$. 
Por el primero de los decretos se prorrogó por el término de sesenta (60) días la suspensión preventiva dispuesta por el Presidente del Instituto de Lotería y Casinos, contra una agente a quien se instruyó un sumario para deslindar responsabilidades por estar presuntamente incursa en una falta.

El expediente tuvo una gestión, desde su caratulación y hasta el dictado del acto, de cuarenta y tres (43) días.

En los restantes cuatro (4) decretos se ratificó la sanción de cesantía dispuesta por resolución del Instituto Provincial de Lotería y Casinos, por haber transgredido cada uno/a de los/as sumariados/as distintos artículos de la Ley $\mathrm{N}^{\circ} 25.164$.

En estos casos, en líneas generales, el Poder Ejecutivo adoptó la decisión de ratificar las sanciones ponderando los puntos que se detallan a continuación:

a) La resolución del Presidente del Instituto que inicia el sumario administrativo tendiente a deslindar responsabilidad disciplinaria.

b) La resolución de la misma Autoridad que declara la existencia de responsabilidad administrativa disciplinaria del agente y aplica, en consecuencia, la sanción expulsiva.

c) La intervención de la Dirección Provincial de Relaciones Laborales, actual Dirección Provincial de Personal ${ }^{31}$ dependiente de la Subsecretaría de Empleo Público y Gestión de Bienes ${ }^{32}$ del Ministerio de Jefatura de Gabinete de Ministros.

31 El Decreto Nº 31/2020, que aprueba la estructura orgánico-funcional del Ministerio de Jefatura de Gabinete de Ministros en el marco de la Ley de Ministerios N 15.164, dispone que la Dirección Provincial de Personal, entre otras acciones, entiende en lo relativo al funcionamiento y pronunciamiento de la Junta de Disciplina, entiende e interviene, en materia de su competencia, en lo relativo a los procedimientos originados por hechos, acciones, u omisiones que pueden derivar en instrucciones sumariales, y fiscaliza la instrucción de los sumarios administrativos e informaciones sumarias originadas por faltas cometidas por agentes de la Administración Pública Provincial. El área responsable de instruir los sumarios es la Dirección de Sumarios Administrativos.

32 Esta Subsecretaría se constituye en el Organismo Central de Personal en los términos del artículo 122 de la Ley $N^{0} 10.430$, que propone los medios e instrumentos para el ejercicio de las facultades del titular del Poder Ejecutivo en materia de administración de personal. 
d) El dictamen de Asesoría General de Gobierno ${ }^{33}$, que verifica que se hayan adoptado todos los recaudos y diligencias pertinentes que hacen al debido proceso legal, garantizado el derecho de defensa del/ de la sumariado/a, y que el obrar de la instrucción se haya ajustado a las pautas establecidas en la legislación vigente, y emite opinión respecto de la medida disciplinaria a aplicar.

En el Decreto $\mathrm{N}^{\circ} 1703 / 19$, además, consta la intervención de Contaduría General de la Provincia requiriendo que, "[u]na vez concluidas las actuaciones pertinentes deberán retornar las mismas a los efectos de su análisis en los términos del artículo 104 inciso p) y concordantes de la Ley 13.767 en forma previa a la declaración y determinación del perjuicio fiscal".

Respecto de los mencionados actos de ratificación, podemos apreciar los datos que detallan a continuación:

- Tiempo insumido en la tramitación de los procedimientos, desde el inicio del expediente hasta la firma del acto:

33 El artículo 95 de la Ley N 10.430 dispone que: “Cuando la falta imputada pueda dar lugar a la aplicación de sanción expulsiva, deberá darse intervención a la ASESORÍA GENERAL DE GOBIERNO para que, dentro del plazo de DIEZ (10) días emita dictamen al respecto. Solamente se requerirá la intervención de la FISCALÍA DE ESTADO cuando de modo directo existan intereses fiscales afectados, la que deberá expedirse dentro del mismo plazo. Ambos organismos podrán recabar medidas ampliatorias."

De igual modo, el inciso 5 del artículo 34 de la Ley No 15.164 refiere que AGG emitirá opinión jurídica en los sumarios administrativos, cuando corresponda medida expulsiva.

En sintonía con ambas prescripciones legales se encuentra la segunda parte del artículo $2^{\circ}$ del Decreto N 4406/96 que "recuerda" la intervención previa del organismo asesor.

Respecto de la Fiscalía de Estado, también tiene una doble manda legal para que tome intervención en este tipo de actuaciones. A lo dispuesto por el citado artículo 95 de la Ley $N^{0} 10.430$, se suma lo establecido por el artículo 38 inciso h) de su Ley Orgánica -Decreto Ley N $N^{0} 7543 / 69$ Texto Ordenado por Decreto No 969/87 y modificatorias-, que reza que "El Poder Ejecutivo y los institutos autárquicos sólo podrán decidir los expedientes en que pudieren resultar afectados los intereses patrimoniales de la Provincia con el previo informe de la Contaduría General, dictamen del Asesor General de Gobierno y vista del Fiscal de Estado. Esta disposición comprende: ...Todo sumario administrativo cuando de modo directo existan intereses fiscales afectados. Se exceptúan los sumarios sustanciados contra personal de Policía y Servicio Penitenciario de la Provincia." 
- Menor plazo: 911 días

- Mayor plazo: 3407 días

- Tiempo promedio de las cuatro actuaciones: 1780 días

- Género de las personas involucradas: masculino.

\section{II.2.3. Decretos relativos a los magistrados Poder Judicial}

En la primera edición de este trabajo, hicimos alusión al proceso que se debe transitar para la designación de los/as jueces/zas en la Provincia. Al respecto, es posible identificar los siguientes estadios dentro del procedimiento referenciado: 1) la selección de los y las postulantes, a practicarse en concursos públicos, que concluye con la terna vinculante decidida por el Consejo de la Magistratura comunicada al Poder Ejecutivo; 2) la propuesta referida a una de las personas postuladas incluida en la terna, formalizada por el Poder Ejecutivo mediante el envío del pliego al Senado; 3) el pronunciamiento del Senado sobre dicha proposición, que, en caso positivo, previo dictamen de la Comisión de Asuntos Constitucionales y Acuerdos, constituye el acuerdo, a votarse en sesión pública; 4) el decreto de nombramiento emanado del Poder Ejecutivo; posteriormente, la toma de posesión del cargo, precedida del juramento del/ de la designado/a ante el órgano judicial competente (conf. arts. 82, 175, 179 y concs., Const. prov.; 25, 28, 29 y concs., Ley $\mathrm{N}^{\circ} 11.868$, con sus reformas; 27 inc. 5 y concs., Ley $\mathrm{N}^{\circ} 15.164$; y doctrina fallos B. 62.241, "Zarlenga" y A. 70.444 "Decastelli").

Como se observa, el procedimiento de designación de funcionarios y funcionarias referido, se integra en un conjunto de decisiones emanadas de diferentes órganos públicos, en el marco de un complejo mecanismo constitucional, que concluye con la designación, toma de juramento y posesión del cargo.

Por último, es importante destacar que mediante el Decreto $N^{o}$ 269/19, la ex Gobernadora designó en el Poder Judicial, Suprema Corte de Justicia, como Juez al Dr. Sergio G. Torres. De esta manera, la primera mandataria cubrió la vacante generada 
por la renuncia del Dr. Hitters aceptada mediante Decreto $\mathrm{N}^{\mathrm{o}} 1117$ del 14 de septiembre de 2016, es decir, cubrió el cargo dos (2) años, cinco (5) meses y quince (15) días corridos, después.

Diremos brevemente que, conforme estipula la Constitución Provincial (artículo 175 y concordantes) y el Decreto $N^{\circ} 735 / 04$, el procedimiento para la designación de los magistrados y magistradas de la Suprema Corte, entre otros/as funcionarios/as consignados en el artículo $1^{\circ}$ del mencionado acto administrativo, deben respetarse los siguientes pasos: en primer lugar, el Poder Ejecutivo local postula al candidato o candidata para ocupar el cargo en los medios de comunicación, promoviendo la publicidad y escrutinio público. Es decir, producida la vacancia en alguno de los cargos referidos se publicará en el Boletín Oficial, en tres (3) diarios de amplia circulación nacional, y en tres (3) diarios de circulación en el territorio de la Provincia, durante tres (3) días, con difusión simultánea en la página oficial de la red de informática del Ministerio de Justicia, el nombre y los antecedentes curriculares de la o las personas que se encuentren en consideración para la cobertura de las respectivas vacantes.

Posteriormente, la o las personas deberán presentar una declaración jurada con la nómina de todos los bienes propios, los de su cónyuge y/o los del conviviente, los que integren el patrimonio de la sociedad conyugal y los de sus hijos menores; como así también la nómina de las asociaciones civiles y sociedades comerciales que integren o hayan integrado en los últimos cinco (5) años, los estudios jurídicos a los que pertenezcan o hayan pertenecido, la nómina de clientes o contratistas durante igual lapso, en el marco de lo permitido por las normas de ética profesional vigentes y, en general, cualquier información que permita evaluar objetivamente la existencia o no de incompatibilidad o conflicto de intereses con la función para la que son propuestas.

Conforme surge del decreto en análisis, los/as ciudadanos/as en general, las organizaciones no gubernamentales, los colegios y asociaciones profesionales, las entidades académicas y de 
derechos humanos, podrán en el plazo de quince (15) días a contar desde la última publicación en el Boletín Oficial, presentar al Ministerio de Justicia, por escrito debidamente fundado y documentado, las observaciones y/o impugnaciones que estimen pertinentes a las nominaciones efectuadas, y que pudieran obstar o deberían ser tenidas en consideración al momento de la selección de los/as nominados/as. Sin perjuicio de ello, se deja aclarado que no serán consideradas aquellas que resulten irrelevantes para la finalidad de la norma o que se funden en cualquier tipo de discriminación. Asimismo, durante el referido plazo podrá requerirse opinión fundada a organizaciones de relevancia en el ámbito profesional, judicial, académico, social, político y de derechos humanos a los fines de su ponderación.

Finalmente, la norma dispone que, en un plazo que no deberá superar los quince (15) días a contar desde el vencimiento del establecido para la presentación de las observaciones y/o impugnaciones, haciendo mérito de las razones que abonaron la decisión tomada, el Poder Ejecutivo, debe disponer sobre la elevación o no de la propuesta respectiva. En caso de decisión positiva, se deberá enviar, con lo actuado, el nombramiento respectivo al Honorable Senado, a los fines del acuerdo. ${ }^{34}$

\section{Designaciones de magistrados en el Poder Judicial}

i. Durante el 2019 se registraron un total de sesenta y nueve (69) designaciones en el ámbito del Poder Judicial provincial, lo que implica una reducción del cuarenta y dos por ciento (42\%) respecto del ciento diecinueve (119) designaciones del año anterior. Dentro de ellas, observamos que sólo veintidós (22) recayeron en candidatas de género femenino, lo que importa un treinta y uno con ochenta y ocho por ciento $(\mathbf{3 1 , 8 8 \%})$ del

\footnotetext{
34 Sobre el particular, consideramos que sería deseable que el Poder Ejecutivo provincial dictara un acto administrativo estableciendo mecanismos de participación ciudadana en la selección de las candidaturas por el Poder Ejecutivo, dentro de la terna elevada por el Consejo de la Magistratura a jueces/zas de tribunales inferiores del Poder Judicial e integrantes del Ministerio Público. Ello contribuiría a mejorar la transparencia del sistema.
} 
total, resultando una caída significativa respecto del cuarenta y cinco con treinta y ocho por ciento $(\mathbf{4 5 , 3 8 \% )}$ que representaron en 2018. Las restantes cuarenta y siete (47) designaciones, que corresponden a un sesenta y ocho con doce por ciento $(\mathbf{6 8}, \mathbf{1 2} \%)^{35}$ del total, recayeron en candidatos del género masculino. Como vemos, no sólo no se revirtió la diferencia relevada en la primera entrega del presente trabajo respecto del género en las designaciones efectuadas por la entonces Gobernadora en el ámbito de la Justicia, sino que, por el contrario, la disparidad se acentuó profundamente. Mientras que en 2018 la diferencia representaba el nueve con veinticuatro por ciento (9,24\%) -equivalente a once (11) designaciones- en beneficio de los miembros del grupo masculino por sobre el femenino, en 2019 la brecha se elevó al treinta y seis con veintitrés por ciento $\mathbf{( 3 6 , 2 3 \% )}$-equivalente a veinticinco (25) designaciones-.

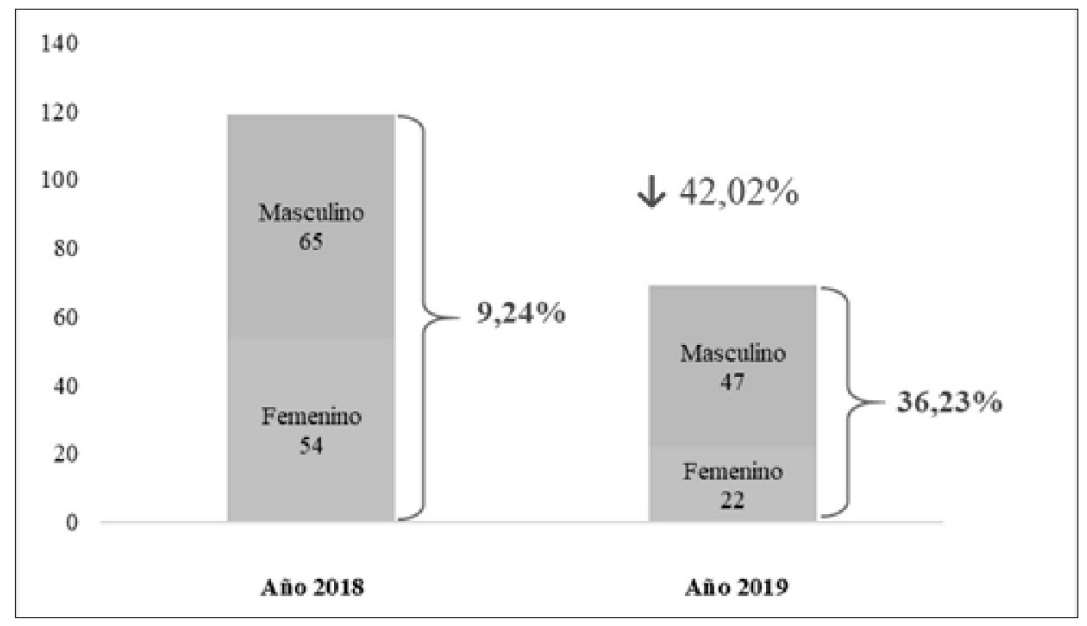

llustración 15. Total de designaciones en el Poder Judicial, apertura por género Comparado con el año anterior. Fuente: elaboración propia

35 Es importante destacar que puede ocurrir que las ternas elevadas desde el Consejo de la Magistratura estuvieran compuestas en su totalidad por hombres o mujeres. Dicha información no surge del acto de designación del candidato finalmente seleccionado por el Poder Ejecutivo. 
En relación a los cargos y fueros de las designaciones, la distribución respecto de las magistradas fue la siguiente: una (1) Jueza de Cámara de Apelación y Garantías en lo Penal, una (1) Jueza en lo Correccional, una (1) Jueza de Ejecución Penal, tres (3) Juezas de Garantías del Joven, tres (3) Juezas de Primera Instancia en lo Civil y Comercial, siete (7) Juezas de Primera Instancia de Familia, dos (2) Juezas de Trabajo y cuatro (4) Juezas de Tribunal Penal. Cabe aclarar que, del total de magistradas designadas durante 2019 , sólo una (1) - cuatro con cincuenta y cinco por ciento $(\mathbf{4 , 5 5 \% )}$ - lo fue con rango de camarista, mientras que al noventa y cinco con cuarenta y cinco por ciento $(\mathbf{9 5}, \mathbf{4 5} \%)$ restantes -correspondiente a veintiuna (21) juezas- se les asignaron cargos en primera instancia.

Respecto de las designaciones de los magistrados del Poder Judicial, la distribución de cargos y fueros, por su parte, fue la siguiente: un (1) Juez del Superior Tribunal; tres (3) Jueces de Cámara de Apelación y Garantías en lo Penal, dos (2) Jueces de Cámara de Apelaciones en lo Civil y Comercial, tres (3) Jueces Correccionales, cuatro (4) Jueces de Ejecución Penal, un (1) Juez de Garantías del Joven, cinco (5) Jueces de Garantías Penal, once (11) Jueces de Primera Instancia en lo Civil y Comercial, dos (2) Jueces de Primera Instancia de Familia, dos (2) Jueces de Responsabilidad Penal Juvenil, un (1) Juez del Cuerpo de Magistrados Suplentes, seis (6) Jueces de Trabajo y seis (6) Jueces de Tribunal Penal. Como podemos observar, se designaron seis (6) camaristas de género masculino, representando el doce con setenta y siete por ciento $(\mathbf{1 2}, 77 \%)$ del total de designaciones del género. Las restantes cuarenta y uno (41) designaciones -correspondientes al ochenta y siete con veintitrés por ciento $(\mathbf{8 7 , 2 3} \%)$ - fueron para que ejerzan como magistrados de primera instancia.

Cabe destacar que en los únicos casos en que se registraron mayor designación de mujeres que de hombres durante el período en estudio, fueron para los cargos de Juez/a de Garantías del Joven ( 3 mujeres y 1 hombre) y de Juez/a de Primera Instancia de Familia (7 mujeres y 2 hombres). 
ii. Respecto del ámbito territorial, las designaciones efectuadas durante 2019 se distribuyeron en los distintos Departamentos Judiciales conforme se indica a continuación: Avellaneda - Lanús, tres (3); Azul, cuatro (4); Bahía Blanca, cuatro (4); Dolores, tres (3); San Martín, una (1); Junín, cuatro (4); La Matanza, cinco (5); La Plata, cuatro (4); Lomas de Zamora, ocho (8); Mar del Plata, tres (3); Mercedes, dos (2); Morón, cinco (5); Necochea una (1); Pergamino, dos (2); Quilmes, seis (6) San Isidro, cinco (5); San Nicolás, seis (6); Trenque Lauquen, una (1); Zárate - Campana, una (1). ${ }^{36}$

Como puede observarse, los departamentos que más designaciones tuvieron fueron los de Lomas de Zamora -ocho (8)-, seguidos por Quilmes y San Nicolás -seis (6). A diferencia del año anterior, en que había contado con la mayor cantidad -diecisiete (17)-, el Departamento Judicial de La Plata, sede de la Suprema Corte, el cual tuvo durante el período objeto de estudio del presente, sólo cuatro (4) designaciones.

iii. La investigación procuró, también, determinar el rango etario de los designados y las designadas. En ese sentido, los datos recabados fueron los siguientes: en relación a los cuarenta y siete (47) hombres designados, podemos señalar que nueve (9) nacieron en la década del '60; treinta y dos (32), en la década del '70; y seis (6), en la década del '80. Por su parte, en referencia al género femenino, de las veintidós (22) designaciones, los datos fueron: dos (2) nacieron la década del '50; cinco (5), en la década del '60; trece (13), en la década del '70; y dos (2), durante la del '80.

iv. Finalmente, debemos indicar que durante el 2019 se dictaron sólo tres (3) decretos que trataron pases de magistrados/as a diferentes salas o juzgados. Estos son los Decretos $\mathrm{N}^{\circ} 708 / 19$, $\mathrm{N}^{\mathrm{o}} 1266 / 19$ y No $1535 / 19$.

36 Recordemos que los Departamentos Judiciales son: La Plata, Lomas de Zamora, Avellaneda-Lanús, Quilmes, Moreno-General Rodríguez, Morón, General San Martín, La Matanza, San Isidro, Zárate Campana, San Nicolás, Pergamino, Junín, Trenque Lauquen, Mercedes, Azul, Mar del Plata, Dolores, Bahía Blanca y Necochea. 


\section{Ceses en el Poder Judicial}

i. Respecto de las renuncias aceptadas en el ámbito del Poder Judicial durante el año 2019, debemos destacar que, de un total de cincuenta (50), treinta y cinco (35) fueron presentadas por magistrados de género masculino y quince (15) por magistradas mujeres. Si bien se advierte una disminución en la cantidad de renuncias aceptadas respecto del año anterior, la diferencia no resulta ser significativa, como en el caso de las designaciones -en 2018 se aceptaron un total de sesenta y nueve (69)-.

Los cargos que quedaron vacantes, como consecuencia de las renuncias aceptadas, fueron los siguientes. Respecto del género masculino: un (1) Juez de Cámara de Apelación y Garantías en lo Penal, cuatro (4) Jueces de Cámara de Apelaciones en lo Civil y Comercial, dos (2) Jueces Correccional, dos (2) Jueces de Garantías del Joven, tres (3) Jueces de Garantías Penal, tres (3) Jueces de Paz, un (1) Juez de Primera Instancia en lo Civil y Comercial, un (1) Juez de Primera Instancia de Familia, ocho (8) Jueces de Trabajo y diez (10) Jueces de Tribunal Penal.

En cuanto al género femenino, la distribución de cargos fue la siguiente: una (1) Jueza de Cámara de Apelaciones en lo Civil y Comercial, una (1) Jueza Correccional, una (1) Jueza de Garantías del Joven, dos (2) Juezas de Primera Instancia en lo Civil y Comercial, ocho (8) Juezas del Tribunal de Trabajo y dos (2) Juezas de Tribunal Penal. 


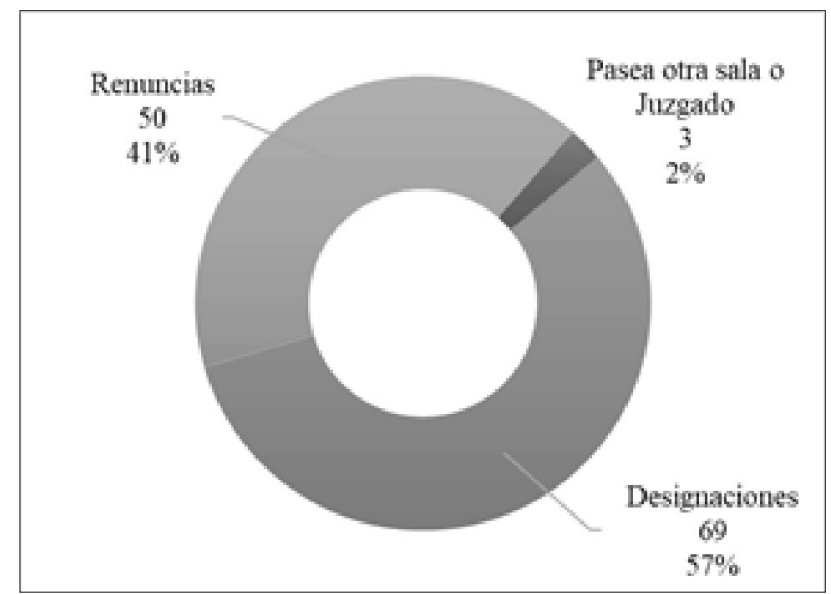

Ilustración 16. Total de decretos del Poder Judicial, apertura por objeto. Fuente: elaboración propia

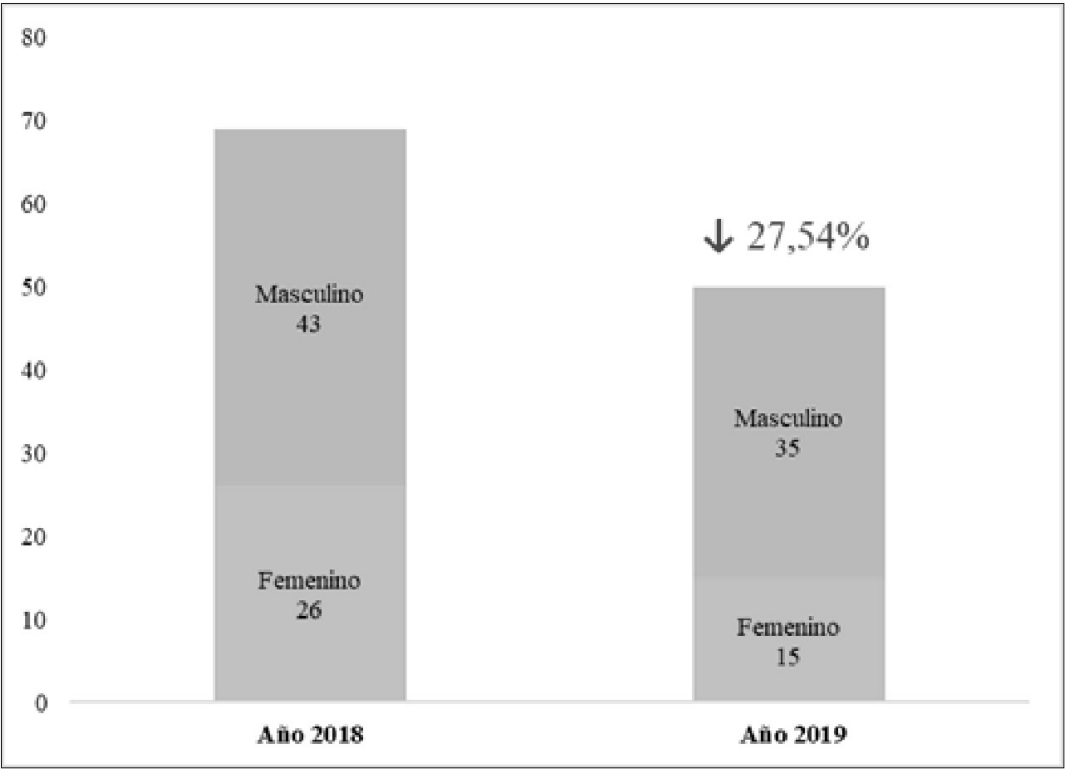

Ilustración 17. Total de renuncias del Poder Judicial, apertura por género Comparado con el año anterior. Fuente: elaboración propia. 


\section{II.2.4. Decretos sobre magistrados del Ministerio Público}

Como vimos en la primera publicación de este trabajo, el proceso de designación de magistrados del Ministerio Público es el mismo que el realizado para los nombramientos en el Poder Judicial. En consecuencia, las advertencias oportunamente efectuadas las reproducimos en esta instancia, a excepción del acto de jura que se encuentra regulado por el artículo $19^{\circ} \mathrm{de}$ la Ley $\mathrm{N}^{\circ}$ 14.442, según el cual el Procurador General presta juramento ante la Suprema Corte de Justicia de la Provincia de Buenos Aires, junto con el Subprocurador General, el Defensor General y el Subdefensor General. ${ }^{37}$

\section{Designaciones en el Ministerio Público}

i. Durante el 2019, se registraron una cantidad total de cuarenta y ocho (48) designaciones de magistrados/as en el ámbito del Ministerio Público provincial, lo que representa un cuarenta con setenta y cuatro por ciento $(40,74 \%)$ menos respecto de las ochenta y una (81) efectuadas durante 2018, observándose una situación similar al Poder Judicial. Dentro de ellas, debemos destacar que veintiuno (21) recayeron en personas de género femenino -representando el cuarenta y tres con setenta y cinco por ciento $(43,75 \%)$ del total- y las restantes veintisiete (27) -correspondientes al cincuenta y seis con veinticinco por ciento $(56,25 \%)$ - de género masculino. Al igual que en el Poder Judicial, existe una diferencia a favor de las personas del género masculino, que representa un doce con cinco por ciento (12,5\%). Si bien el porcentaje es menor que en el caso de los jueces y juezas, llama la atención que el Ministerio Público evidencia una inversión respecto del año anterior, ya que durante 2018

\footnotetext{
37 Por su parte, El Fiscal y el Defensor del Tribunal de Casación, los Fiscales de Cámara y los Defensores Departamentales, deberán prestar juramento ante el Procurador General o Defensor General, respectivamente. Los Adjuntos del Fiscal y del Defensor del Tribunal de Casación lo harán ante sus respectivos titulares. Los restantes miembros del Ministerio Público deberán prestar juramento ante el Fiscal de Cámara y Defensor Departamental.
} 
hubo un ocho con sesenta y cuatro por ciento $(8,64 \%)$ más de designaciones del género femenino que masculino.

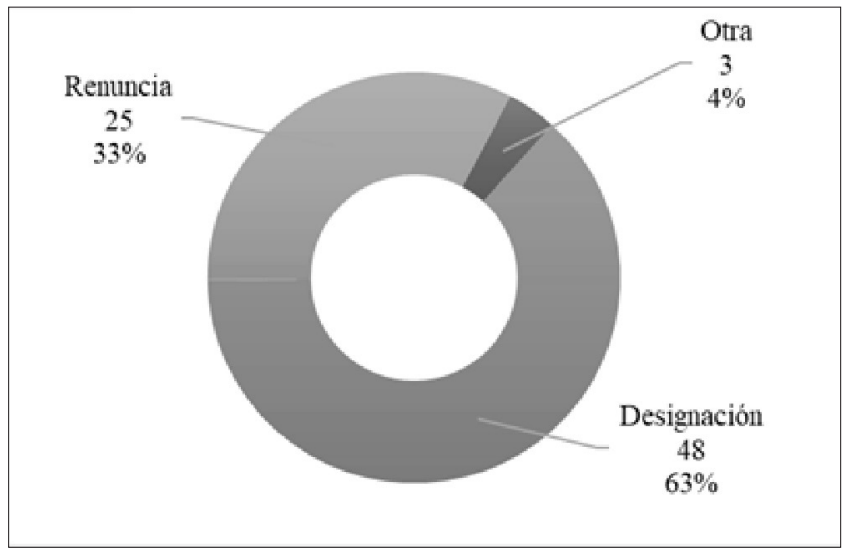

Ilustración 18. Total de Decretos del Ministerio Púbico, apertura por objeto. Fuente: elaboración propia.

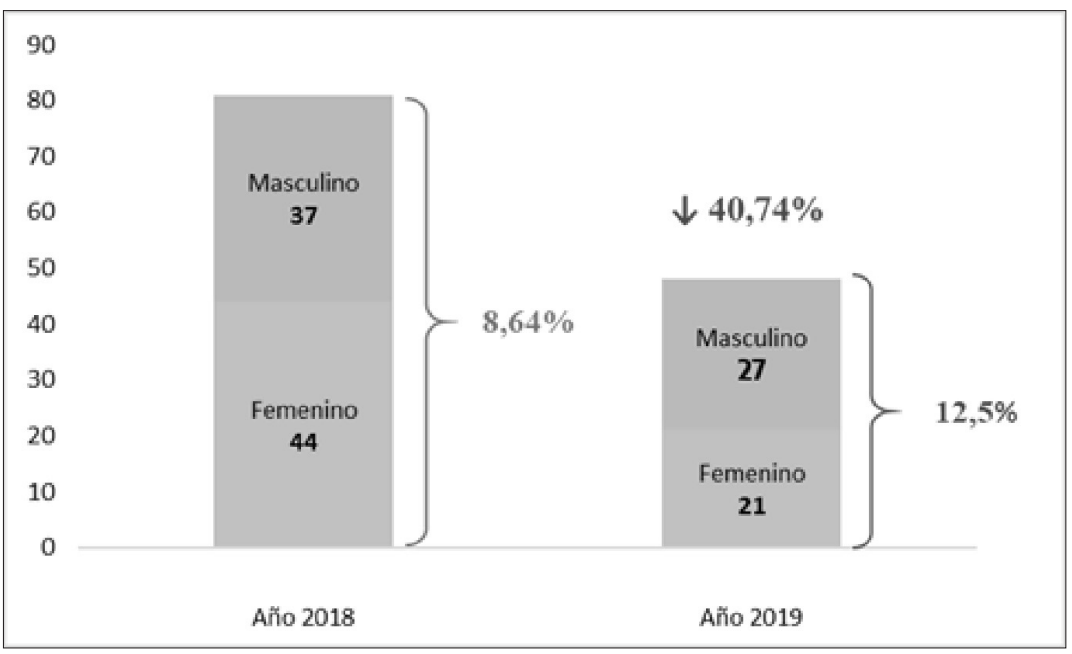

Ilustración 19. Total de designaciones del Ministerio Púbico, apertura por género comparado con el año anterior. Fuente: elaboración propia. 
Las designaciones de las candidatas a magistradas recayeron en los siguientes cargos: una (1), en el Cuerpo de Magistrados Suplentes del Ministerio Público; cinco (5) Agentes Fiscales; seis (6) Asesoras de Incapaces; tres (3) Defensoras Departamentales; y seis (6) Defensoras Oficiales.

En cuanto a los magistrados, la distribución de los cargos se produjo de la siguiente manera: tres (3), para el Cuerpo de Magistrados Suplentes del Ministerio Público; once (11) Agentes Fiscales; un (1) Asesor de Incapaces; un (1) Defensor Departamental; diez (10) Defensores Oficiales; y un (1) Fiscal General.

ii. En relación al ámbito territorial, las designaciones de magistradas en el Ministerio Público recayeron en los siguientes Departamentos Judiciales: cinco (5), en Avellaneda - Lanús; una (1) en Azul; una (1) en Dolores; una (1) en Junín; una (1) en La Plata; una (1) en Mercedes; dos (2) en Moreno - General Rodríguez; una (1) en Morón; una (1) en Quilmes; tres (3) en San Isidro; una (1) San Nicolás; una (1) Zárate - Campana; una (1) General San Martín y una (1) en Departamentos varios, que es el caso de magistrados/as suplentes.

Por su parte, las designaciones de los magistrados se distribuyeron en los siguientes Departamentos Judiciales: dos (2) en Azul; uno (1) en Dolores; tres (3) en General San Martín; uno (1) en Junín; dos (2) en La Matanza; dos (2) en La Plata; tres (3) en Lomas de Zamora; tres (3) en Moreno - General Rodríguez; tres (3) Necochea; tres (3) en San Isidro; uno (1) Zárate - Campana; y tres (3) en Departamentos varios, que es el caso de magistrados suplentes.

iii. Finalmente, en cuanto al rango etario de las designaciones en el ámbito del Ministerio Público, el análisis estadístico realizado nos arrojó los siguientes datos: en relación al género masculino, seis (6) nacieron en la década del '60; trece (13), en la del '70; y, finalmente, ocho (8), en la década del '80. Por su parte, en referencia al género femenino, podemos indicar que cuatro (4) nacieron en la década del '60; diez (10), durante los '70; y siete (7) en la década siguiente. 


\section{Ceses en el Ministerio Público}

i. Respecto de las renuncias en el ámbito del Ministerio Público, durante el año 2019 se aceptaron un total de veinticinco (25), lo que representa un cuarenta y cinco con sesenta y cinco por ciento (45.65\%) menos que en 2018 -durante este período se aceptaron cuarenta y seis (46)-. Del referido total, diez (10) fueron presentadas por personas del género femenino, mientras las restantes quince (15) pertenecen al género masculino.

Los cargos que quedaron vacantes como consecuencia de las renuncias aceptadas durante el año en cuestión fueron los siguientes. Respecto del género masculino, ocho (8) fueron Agentes Fiscales y siete (7) Defensores Oficiales. En cuanto al género femenino, la distribución de cargos fue la siguiente: cuatro (4) Agentes Fiscales, dos (2) Asesoras de Incapaces y cuatro (4) Defensoras Oficiales.

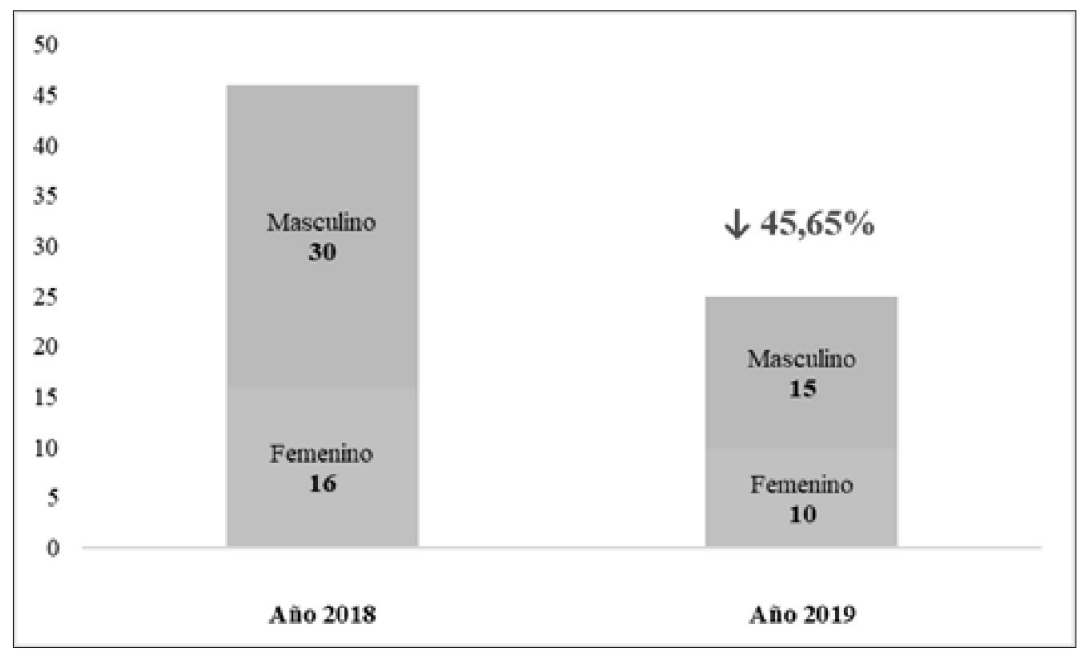

llustración 20. Total de renuncias en el Ministerio Púbico, apertura por género comparado con el año anterior. Fuente: elaboración propia.

ii. De un total de veinticinco (25) renuncias presentadas en el ámbito del Ministerio Público provincial, veinticuatro (24) 
fueron con el propósito de acogerse a los beneficios jubilatorios. Encontramos una única excepción, que es el Decreto $\mathrm{N}^{\circ} 76 / 19$, mediante el cual se aceptó, a partir del 14 de febrero de 2019, la renuncia presentada por A. M. A. al cargo de Agente Fiscal del Departamento Judicial San Martín. Conforme surge de la parte considerativa del acto administrativo, la magistrada en su renuncia esgrimió motivos personales para dejar el cargo.

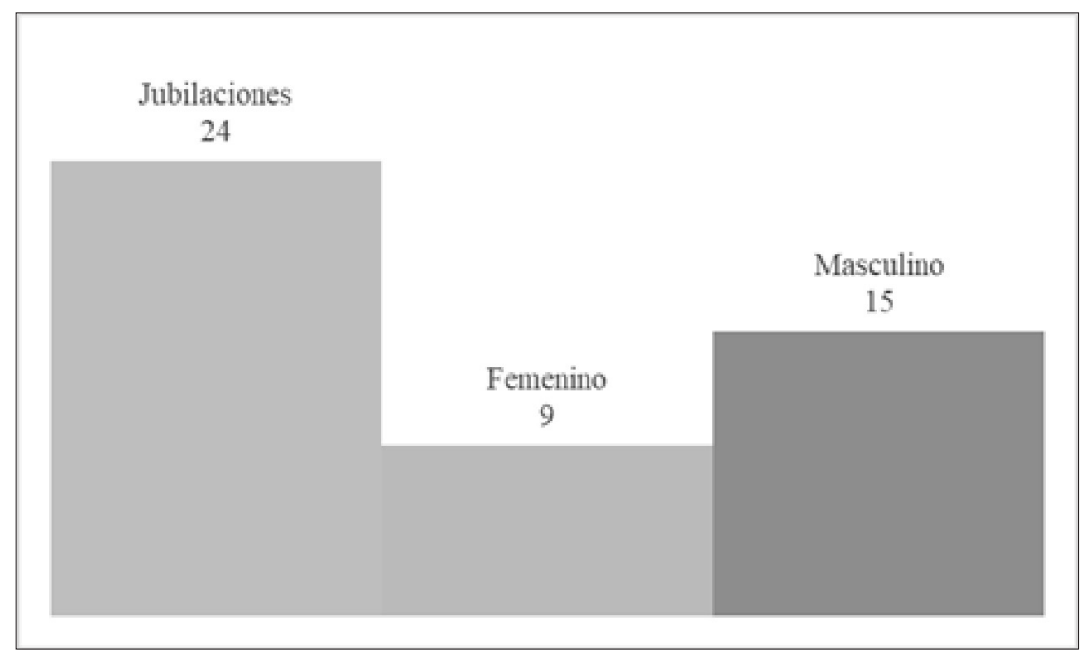

llustración 21. Cantidad de renuncias por motivos jubilatorios en el Ministerio Púbico, apertura por género. Fuente: elaboración propia.

Por otro lado, es importante destacar que mediante los Decretos $N^{\circ} 709 / 19$ y $710 / 19$, se dejaron sin efecto las designaciones efectuadas en favor de los doctores E.S. B. en el cargo de Agente Fiscal del Departamento Judicial La Matanza, sede cabecera o descentralizada (Decreto $\mathrm{N}^{\circ} 313 / 17$ ), y de M. F. I. en el cargo de Agente Fiscal del Departamento Judicial San Nicolás, sede Arrecifes (Decreto $N^{\circ} 370 / 17$ ). En ambos casos, los actos administrativos en estudio refieren que los mencionados no prestaron el correspondiente juramento de ley al cargo para el que fueron oportunamente designados. 
Finalmente, debemos señalar que mediante Decreto $N^{\circ} 1180 / 19$, la ex Gobernadora rechazó la renuncia presentada por el Agente Fiscal de la Unidad Funcional de Instrucción $\mathrm{N}^{\mathrm{o}} 11$ del Departamento Judicial Azul, sede Olavarría. Conforme surge de la parte considerativa del acto analizado, la decisión se fundamenta en que la aceptación de la renuncia tendría "una incidencia gravitante" en distintas investigaciones en curso seguidas contra el magistrado. Cabe destacar que, contra dicho acto, el mencionado Agente Fiscal interpuso recurso de revocatoria, en los términos del artículo 89 del Decreto-Ley $\mathrm{N}^{\circ} 7647 / 70$, al cual hizo lugar el Decreto $\mathrm{N}^{\circ}$ 925/2020.

\section{II.2.5. Decretos sobre política salarial}

En este apartado nos referiremos a los decretos dictados durante el período en análisis referidos a la política salarial de los/as empleados/as del Estado provincial. Procederemos a enumerar los decretos dictados en el año 2019, estableciendo una comparación cuantitativa con el periodo anterior, para luego tomar el Decreto $\mathrm{N}^{\circ} 1254 / 19$, a modo ejemplificativo -la elección del mismo no es azarosa, puesto que a nuestro entender fue el más significativo- y analizarlo, haciendo especial mención al procedimiento establecido por Ley $\mathrm{N}^{\circ} 13.453$, en cuyo marco se desarrollaron los acuerdos paritarios que dieron fundamento al dictado del acto referido, así como la mayoría de los decretos relativos a la temática.

En efecto, se señala que durante el año 2019 se dictaron un total de treinta y siete (37) decretos de políticas salariales, de los cuales quince (15) se dieron en el marco de acuerdos paritarios regulados por la Ley $\mathrm{N}^{\circ} 13.453$, incluyendo cláusulas de adecuación salarial, y cuatro (4) en el marco de las negociaciones colectivas reguladas por la Ley $\mathrm{N}^{\circ} 13.552$ para el personal docente de la provincia de Buenos Aires. Los restantes decretos refieren a: i) implementación de incrementos salariales para personal que no se encuentra regido por la Ley $\mathrm{N}^{\circ} 13.453$ (trabajadores y trabajadoras de las fuerzas de seguridad, personal jerarquizado 
superior, agentes, funcionarios y magistrados del Poder Judicial), ii) otorgamiento de bonificaciones específicas sectoriales o modificaciones sobre las mismas y iii) regulación del régimen de asignaciones familiares para todos los/as empleados/as de la Administración Pública Provincial.

Del análisis comparativo con el año 2018, se evidencia un considerable aumento de los actos suscriptos en torno a esta temática, ya que en aquella oportunidad se registraron sólo veinticinco (25) decretos, lo que se traduce en un incremento del cuarenta y ocho por ciento $(48 \%)$ con relación a la producción de actos del año antecedente.

Sentado ello, analizaremos el Decreto $N^{\circ} 1254 / 19$, mediante el cual se formalizaron los aumentos pactados en la política salarial de los años 2018 y 2019 para el personal dependiente de la Administración Pública provincial, enmarcado en el régimen de la Ley $\mathrm{N}^{\circ}$ 10.430. El decreto citado normativiza el resultado de la negociación acaecida entre distintos representantes de la Administración Pública y de las organizaciones gremiales, materializada a través de diversas audiencias, que culminaron con la suscripción de dos (2) actas paritarias.

En ese sentido, la Ley $\mathrm{N}^{\circ} 13.453$ establece un procedimiento especial para las negociaciones colectivas que se celebren entre la Administración Pública provincial y sus empleados/as, previendo la conformación de comisiones negociadoras integradas por ambas partes -con un máximo de diez (10) representantes por cada una- con el objeto de adoptar decisiones de manera coordinada con el Ministerio de Trabajo, en lo referido a las cuestiones laborales que integren la relación de empleo (tanto de contenido salarial como de temas vinculados a la prestación de servicios y condiciones de trabajo). Como resultado de las negociaciones llevadas a cabo por las comisiones negociadoras, se suscriben las actas pertinentes, en donde se refleja lo acordado, debiendo ser aprobadas, posteriormente, mediante el dictado del decreto correspondiente dentro del plazo de treinta (30) días desde su suscripción. 
Como particularidad del Decreto $\mathrm{N}^{\circ} 1254 / 19$, puede enunciarse la incorporación de una cláusula de adecuación salarial, con operatividad desde el mes de julio de 2019, para el supuesto en que la inflación acumulada en el periodo comprendido entre el $1^{\circ}$ de enero y el 31 de julio del 2019, resultara superior al dieciséis por ciento (16\%) de aumento salarial acumulado, tomando como referencia lo informado por el Instituto Nacional de Estadística y Censos (INDEC) respecto del Índice de Precios al Consumidor (IPC) Nacional.

Asimismo, la mentada norma dispuso el pago -con carácter extraordinario- de un Complemento por Calidad y Continuidad del Servicio, no remunerativo y no bonificable, destinado a las y los agentes involucradas/os en la política salarial, fijándose a tal efecto un importe de pesos seis mil setecientos cincuenta (\$ 6.750) anuales para tal concepto, tanto para el año 2018 como para el siguiente. ${ }^{38}$

Finalmente, es dable destacar que la pauta salarial formalizada por el Decreto $\mathrm{N}^{\circ} 1254 / 19$, fue replicada con posterioridad en la mayoría de los regímenes estatutarios que coexisten en el ámbito del empleo público provincial.

\section{II.2.6. Decretos relativos a estructuras organizativas}

i. Inicialmente, debemos destacar que durante el año 2019 se dictaron ocho (8) decretos relativos a estructuras organizativas de organismos públicos. La cifra indica una considerable disminución respecto de los veinticuatro (24) que se habían

\footnotetext{
38 El Decreto N 832/2020 estableció la continuidad del pago del complemento en concepto de "Calidad y Continuidad del Servicio" de carácter extraordinario, no remunerativo, no bonificable, de pesos seis mil setecientos cincuenta (\$6.750) anuales por el año 2020, por persona, a razón de pesos mil seiscientos ochenta y siete con cincuenta centavos $(\$ 1.687,50)$ por trimestre, conforme las previsiones contenidas en el Acta $N^{0}$ 29/2018 de la Comisión Paritaria General regida por Ley N 10.430 del 27 de noviembre de 2018 y de acuerdo a lo estipulado en su Anexo Único, hasta tanto la Comisión Paritaria General regida por Ley $N^{0} 10.430$, como asimismo las Comisiones Sectoriales correspondientes al año 2020, resuelvan sobre la continuidad del complemento en cuestión.
} 
dictado el año anterior. Ello se debe, principalmente, a que el $1^{\circ}$ de enero de 2018 entró en vigencia la Ley de Ministerios $\mathrm{N}^{\mathrm{o}}$ 14.989, sancionada el 14 de diciembre de 2017, promulgada el 28 de diciembre de ese año y publicada al día siguiente. Esta situación generó lo que en la primera publicación de la presente investigación señalamos como un "juego en dominó" en lo que respecta a la estructura administrativa de la provincia de Buenos Aires.

ii. A pesar de no encontrarse vigente al momento del dictado de los actos administrativos en análisis, una norma ordenadora para la formulación, tramitación y aprobación de las estructuras organizativas, como los Decretos $N^{\circ} 18 / 91$ y $N^{\circ} 1322 / 05$, comentados en la primera entrega de la presente, o el Decreto $\mathrm{N}^{\mathrm{o}} 770 / 2020$, que al momento de realizarse esta descripción se encuentra vigente, se advierten ciertas notas comunes, las cuales referiremos a continuación.

Así, en primer lugar, se advierte que en todos los trámites tomaron intervención a) la Subsecretaría de Capital Humano de Jefatura de Gabinete de Ministros, por sí o a través de sus dependencias -Dirección Provincial de Planificación y Gestión Estratégica del Capital Humano o la Dirección Provincial de Relaciones Laborales-; b) la Subsecretaría de Hacienda, dependiente del Ministerio de Economía, por sí o a través de la Dirección Provincial de Presupuesto Público; y c) Asesoría General de Gobierno. La única excepción la constituye el Decreto $N^{\circ} 16 / 19$, en cuyo trámite, además de los organismos referidos, tomó intervención Fiscalía de Estado.

El segundo aspecto que pondremos de manifiesto, es que en todos los casos refrendaron el acto administrativo el titular de la jurisdicción cuya estructura organizativa se aprueba o modifica y los Ministros Secretarios en los Departamentos de Economía y Jefatura de Gabinete de Ministros. Nuevamente aparece como excepción el Decreto $\mathrm{N}^{\mathrm{o}} 16 / 19$, el cual fue refrendado por el Ministro de Trabajo y de Jefatura de Gabinete de Ministros, pero no así el de Economía. Ello puede deberse a que la gestión tuvo 
por objeto suprimir la nómina de las Coordinaciones de Delegaciones Regionales de Trabajo y Empleo aprobada por Decreto $N^{o}$ 172/18; al tiempo que se facultó al Señor Ministro de Trabajo a determinar las áreas geográficas a cargo de las referidas coordinaciones. Como se advierte, el decreto en cuestión no implicó un aumento o disminución en la cantidad de unidades organizativas de la cartera ministerial y, por lo tanto, no generó un impacto presupuestario. Sin embargo, ello es contradictorio con la intervención en las actuaciones administrativas de la Dirección Provincial de Presupuesto Público, de la cual da cuenta la parte considerativa del decreto bajo análisis.

Finalmente, debemos señalar que de los ocho (8) decretos dictados sobre estructuras orgánico-funcionales de la Administración Pública provincial, siete (7) refieren a organismos cuya estructura organizativa ya se encontraba aprobada por decreto. Como excepción encontramos el Decreto No $1345 / 19$, aprobatorio de la estructura orgánico-funcional del Ministerio de Gestión Cultural, cuyas particularidades señalaremos oportunamente.

\begin{tabular}{|l|c|}
\hline Órgano Promotor (Superior) & \# Decretos \\
\hline Gobierno & 2 \\
\hline Infraestructura y Servicios Públicos & 1 \\
\hline Dirección Provincial de Vialidad & 1 \\
\hline Jefatura de Gabinete de Ministros & 1 \\
\hline Trabajo & 1 \\
\hline Asuntos Públicos & 1 \\
\hline Gestión Cultural & 1 \\
\hline Total & $\mathbf{8}$ \\
\hline
\end{tabular}

Ilustración 22. Cantidad de decretos refrendados por órgano promotor. Fuente: elaboración propia.

iii. Previo a pasar revista de cada uno de los actos administrativos en particular, debemos resaltar que de los ocho (8) decretos, las actuaciones de siete (7) de ellos tramitaron por expediente electrónico y sólo uno (1) en expediente papel. 
Este último tuvo una demora de setecientos dieciocho (718) días, mientras que el promedio del plazo de tramitación de los expedientes electrónicos es de ciento ochenta y dos (182) días.

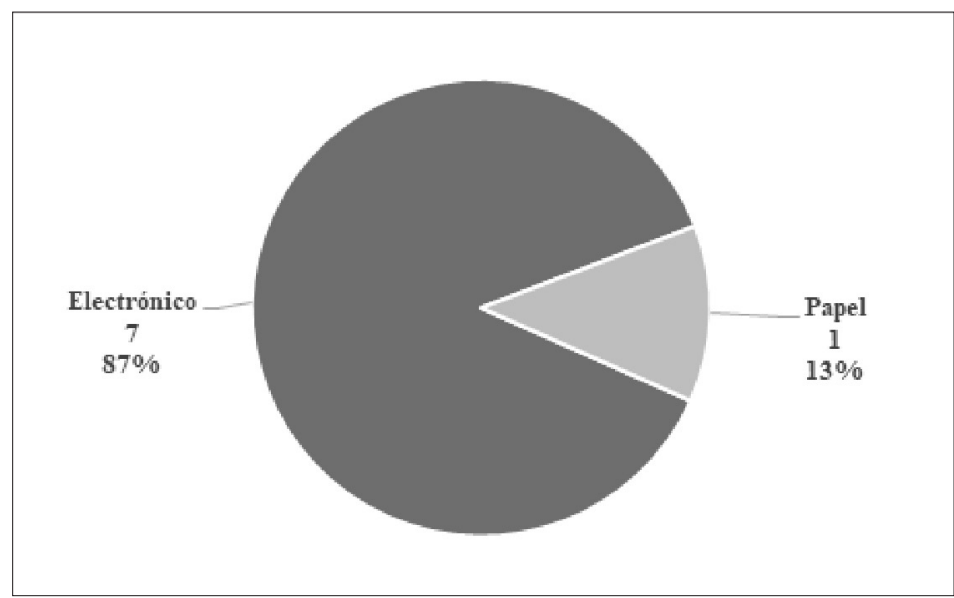

llustración 23. Total de decretos de Estructuras por tipo de expediente. Fuente: elaboración propia.

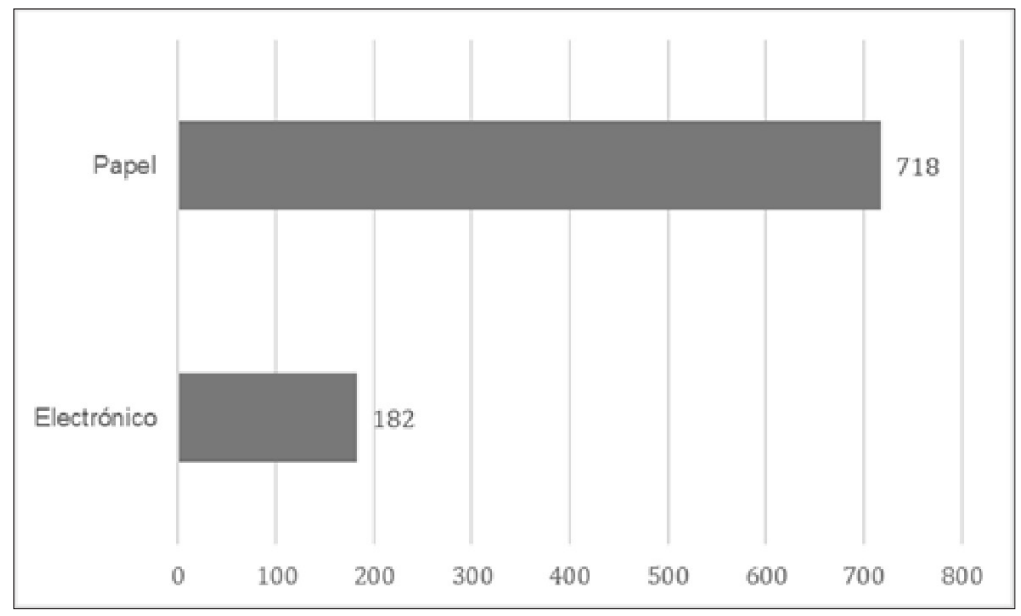

Ilustración 24. Demora promedio de la tramitación de Estructuras por tipo de expediente. Fuente: elaboración propia. 
iv. Sentado ello, haremos un breve resumen de los ocho (8) decretos sobre estructuras orgánico-funcionales dictados durante el período de tiempo en análisis:

a) Decreto $\mathrm{N}^{\circ}$ 16/19: como dijéramos ut supra, suprimió la nómina de las Coordinaciones de Delegaciones Regionales de Trabajo y Empleo aprobada por Decreto $N^{\circ}$ 172/18 y facultó al Señor Ministro de Trabajo a determinar las áreas geográficas a cargo de dichas coordinaciones.

b) Decreto $N^{o} 132 / 19$ : aprobó, a partir del $1^{\circ}$ de enero de 2019, la modificación de la estructura orgánico-funcional de la Subsecretaría de Transporte del Ministerio de Infraestructura y Servicios Públicos, aprobada por Decreto $N^{\circ} 35 / 18$. El acto en cuestión determinó una (1) Subsecretaría, tres (3) Direcciones Provinciales y ocho (8) Direcciones; lo que implicó un aumento de una (1) Dirección Provincial y tres (3) Direcciones.

c) Decreto $\mathrm{N}^{\circ}$ 704/19: aprobó la modificación, a partir del $1^{\circ}$ de abril de 2019, de la estructura orgánico-funcional del Ministerio de Jefatura de Gabinete de Ministros, aprobada por el Decreto $N^{\circ} 34 / 18$. La gestión tuvo por finalidad crear la Dirección Provincial de Asistencia Integral Telefónica, en el ámbito de la Subsecretaría de Atención Ciudadana, lo que implicó un aumento, en el ámbito de la referida cartera ministerial de una (1) Dirección Provincial, dos (2) Direcciones y dos (2) Departamentos.

d) Decreto No 904/19: aprobó, en el ámbito de la Dirección de Vialidad de la Provincia de Buenos Aires, la Unidad Coordinadora de Programas (UCP), determinando para su estructura organizativa un (1) cargo de Responsable Ejecutivo de la Unidad Coordinadora de Programas con rango y remuneración equivalente a Gerente de la Dirección de Vialidad de la Provincia de Buenos Aires, equiparado al cargo de Ingeniero Jefe de la Ley $\mathrm{N}^{\mathrm{o}} 10.328$ - Estatuto para el personal de la Planta Permanente de la Dirección de Vialidad de la Provincia de Buenos Aires-. Conforme surge de la parte considerativa del decreto analizado, la creación de la unidad responde a la necesidad de contar, 
en el ámbito de la referida Dirección de una unidad organizativa con facultades suficientes para coordinar, administrar, planificar, evaluar, supervisar, contratar y controlar la ejecución e implementación de los programas y proyectos viales con financiamiento externo. Ello como consecuencia de la entrada en vigencia del Contrato de Préstamo $N^{\circ}$ ARG-36/2017, para la realización del "Proyecto de Conectividad del Conurbano en la Provincia de Buenos Aires", suscripto entre la provincia de Buenos Aires y el Fondo Financiero para el Desarrollo de la Cuenca del Plata (FONPLATA) aprobado por el Ministerio de Economía de la provincia de Buenos Aires, a través de la Resolución $\mathrm{N}^{\circ} 83$ de fecha 13 de marzo de 2018; de la aprobación por parte del Banco de Desarrollo de América Latina -CAF- de préstamo a favor de la provincia de Buenos Aires para el financiamiento del Programa de Conectividad Vial e Infraestructura Productiva para la Provincia de Buenos Aires; y de la aprobación, por medio del Decreto del Poder Ejecutivo Nacional No 1196/18, de los Modelos de Contrato de Garantía y Contragarantía, con la finalidad de afianzar las obligaciones financieras que se asumirán como consecuencia del Contrato de Préstamo destinado a la ejecución del "Programa de Ampliación de Capacidad y Seguridad en Corredores Viales de la Provincia de Buenos Aires" propuesto para ser suscripto entre la citada Provincia y el Banco Interamericano de Desarrollo (BID); todos ellos, según refiere el decreto, tienen como organismo ejecutor a la Dirección de Vialidad de la Provincia de Buenos Aires.

e) Decreto $\mathrm{N}^{\circ}$ 1247/19: aprobó la estructura orgánicofuncional del Ministerio de Asuntos Públicos, a partir del $1^{\circ}$ de enero de 2019. El decreto en análisis no implicó un cambio cuantitativo en la estructura organizativa del organismo respecto de su predecesor, el Decreto $N^{\circ} 37 / 18$. Así, la jurisdicción mantuvo sus dos (2) Subsecretarías, cinco (5) Direcciones Provinciales y trece (13) Direcciones.

f) Decreto $N^{\circ} 1345 / 19$ : en la entrega anterior de la presente investigación señalamos que, como consecuencia de la entrada 
en vigencia de la Ley de Ministerios $N^{\circ} 14.989$, los organismos en ella previstos proyectaron y aprobaron sus respectivas estructuras organizativas, advirtiendo que "La única excepción la constituye, actualmente, el Ministerio de Gestión Cultural que, al momento de elaborarse el presente trabajo, aún continúa rigiéndose por la estructura aprobada en 2016 (Decretos $\mathrm{N}^{\mathrm{o}} 47 / 16$ y $\mathrm{N}^{\circ} 503 / 16$ ). Esta situación resulta curiosa ya que las mencionadas normas establecen la estructura organizativa de la Secretaría de Cultura, que fue reemplazada por el Ministerio de Gestión Cultural mediante Ley No 14.832.” El Decreto $\mathrm{N}^{\mathrm{o}} 1345 / 19$ vino a salvar esa omisión, aprobando la estructura orgánico-funcional del Ministerio de Gestión Cultural, a partir del $1^{\circ}$ de enero de 2019 y determinando tanto cargos de la Ley $\mathrm{N}^{\mathrm{o}} 10.430$, como de las Leyes $\mathrm{N}^{\mathrm{o}} 12.268$ y N $\mathrm{N}^{\mathrm{o}} 13.056$, relativas a la carrera artística.

g) Decreto $N^{\circ}$ 1533/19: aprobó una modificación parcial de la estructura organizativa del Ministerio de Gobierno en relación a la Dirección Provincial de Ordenamiento Urbano y Territorial dependiente de la Subsecretaría de Gobierno y Asuntos Políticos del Ministerio de Gobierno que había sido transferida desde el Ministerio de Infraestructura y Servicios Públicos mediante Decreto $N^{o}$ 1668/18. El decreto comentado determinó para la estructura orgánico-funcional de la referida Dirección Provincial tres (3) Direcciones y ocho (8) Departamentos.

h) Decreto $N^{\circ}$ 1693/19: aprobó la desagregación de la estructura orgánico-funcional del Ministerio de Gobierno aprobada por Decreto $N^{o} 169 / 18$ y complementada por el decreto previamente referido. La presente constituye la única desagregación integral efectuada durante el año 2019 y determinó cuarenta y cinco (45) Subdirecciones y noventa y un (91) Departamentos.

\section{II.2.7. Decretos de delegación de competencias}

i. En primer lugar, señalaremos que, durante el año 2019 se dictaron cuatro (4) decretos mediante los cuales la entonces Gobernadora delegó facultades en los Ministros de Economía 
(Decretos $\mathrm{N}^{\circ}$ 1/19 y N 210/19), de Infraestructura y Servicios Públicos (Decreto No 44/19) y de Gobierno (Decreto No 183/19). Se advierte un aumento respecto del año anterior, en el cual se dictaron dos (2) decretos sobre la temática.

ii. Sentado ello, haremos mención al trámite llevado a cabo para el dictado de los decretos de delegaciones. En ese entendimiento, debemos señalar que el órgano delegado será quien inicie las actuaciones, quedando a su cargo la proyección del acto administrativo y debiendo obtener los informes previos que garanticen la legalidad, acierto y oportunidad de la iniciativa. Por último, previo al dictado de la medida, deberá darse intervención a la Asesoría General de Gobierno y, de corresponder según la temática, al Fiscal de Estado.

Asimismo, se requerirá un informe a la Contaduría General de la Provincia, cuando se deban interpretar las disposiciones legales y reglamentarias en materia de su competencia y asesorar en dicho aspecto a los organismos de la Administración provincial (art. 90 inc. b) Ley $\mathrm{N}^{\circ}$ 13.767).

iii. A continuación, pasaremos a analizar cada uno de los actos, a saber:

a) Decreto $\mathrm{N}^{\circ}$ 1/19: delega, en el entonces Ministro de Economía, las facultades conferidas por los artículos 15, 16, 17, 22, 23, 24, 113, 115 y 118 de la Ley $\mathrm{N}^{\circ} 15.078$ - de Presupuesto General Ejercicio 2019- , el artículo $2^{\circ}$ de la Ley $\mathrm{N}^{\circ} 10.189$ (T.O. según Decreto $\mathrm{N}^{\circ} 4502 / 98$ ) y el artículo $4^{\circ}$ de la Ley $\mathrm{N}^{\circ} 13.863$. Sin perjuicio de ello hace la salvedad de que el órgano deberá actuar - en ejercicio de las facultades delegadas- con la previa intervención de la Dirección Provincial de Presupuesto Público del citado Ministerio y de la Contaduría General de la Provincia.

La finalidad de la delegación, entre otras, es autorizar al Ministro de Economía a ampliar, reestructurar, modificar, adecuar, créditos presupuestarios, previo cumplimiento de los requisitos, y con las limitaciones propias de la ley.

El fundamento que se esgrime para el dictado de la norma es la propia autorización establecida en la ley, para delegar en 
el Ministro Secretario en el Departamento de Economía tales facultades.

La medida es dictada en ejercicio de las atribuciones conferidas por la Ley de Presupuesto citada ut supra y, asimismo, por el art 144 -proemio- de la Constitución provincial.

b) Decreto $\mathrm{N}^{\circ}$ 44/19: delega, en los términos del artículo 20 de la Ley $\mathrm{N}^{\mathrm{0}}$ 15.078, en el Ministro de Infraestructura y Servicios Públicos, las facultades asignadas por el artículo 16 de la mencionada ley, para efectuar reestructuraciones, modificaciones y transferencias de créditos presupuestarios asignados a erogaciones de capital y gastos de funcionamiento, tanto del Ministerio a su cargo, como de la Autoridad del Agua, el Instituto de la Vivienda, la Dirección de Vialidad y el Comité de Cuenca del Río Reconquista (COMIREC).

Los límites que impone al ejercicio de las facultades delegadas son la prohibición de modificar: i) las fuentes de financiamiento y ii) la afectación de los recursos asignados en la ley.

Asimismo, establece que deberá contar con la intervención favorable de Dirección Provincial de Presupuesto Público y la Contaduría General de la Provincia, debiendo comunicarles todos los actos dictados en el ejercicio del referido decreto a dichos organismos en un plazo máximo de dos (2) y diez (10) días respectivamente.

El argumento en el que anida la delegación es, al igual que en el Decreto $N^{o} 1 / 19$, la autorización conferida por la Ley de Presupuesto para el ejercicio 2019. En ese sentido, justifica la intervención previa de la Dirección Provincial de Presupuesto Público en la propia Ley $\mathrm{N}^{\circ} 13.767$, que la designa órgano rector del Subsistema Presupuestario del Sector Público Provincial.

Cabe destacar que la medida es dictada en ejercicio de la misma normativa que en el decreto analizado anteriormente.

c) Decreto $N^{\circ}$ 183/19: por medio de este decreto se delega en el Ministerio de Gobierno la aprobación establecida en el artículo 83 del Decreto-Ley No 8912/77 (T.O. 1987). 
Para una mejor comprensión, conviene hacer una breve mención al decreto-ley citado, el cual rige el ordenamiento del territorio de la provincia de Buenos Aires en lo relativo al uso, ocupación, subdivisión y equipamiento del suelo, estableciendo pautas que deberán ser observadas por los municipios en su carácter de responsables primarios de tal ordenamiento.

En ese entendimiento, el artículo 83, establece un procedimiento que debe ser seguido por el Municipio: las ordenanzas correspondientes a las distintas etapas de los planes de ordenamiento, son sancionados una vez que dichas etapas son aprobadas por el Poder Ejecutivo, quien toma intervención previo dictamen de los organismos provinciales competentes a fin de verificar que se cumplan ciertos requisitos como: i) objetivos y estrategias definidos por el Gobierno Provincial, ii) compatibilidad con los objetivos y estrategias previstos para los Municipios linderos, iii) concordancia con la normativa provincial y disposiciones reglamentarias, etc.

En otras palabras, el decreto-ley, a través del artículo en cuestión, pone un límite al poder municipal, estableciendo un procedimiento complejo para poner en vigencia las ordenanzas que se dicten dentro de este marco normativo. De este modo, los actos emanados del municipio quedan subordinados a la aprobación de la autoridad máxima del Poder Ejecutivo provincial. Esta última competencia, se encuentra delegada, mediante el decreto en análisis, al Ministerio de Gobierno.

Como fundamento de la medida, la ex Gobernadora de la Provincia, menciona el artículo $3^{\circ}$ del Decreto-Ley $N^{\circ} 7647 / 70$ y enumera las distintas fuentes de las que emanan las competencias de los órganos de la Administración Pública: i) la Constitución de la Provincia; ii) las leyes orgánicas administrativas; y iii) los reglamentos que dicte el Poder Ejecutivo, destacando que aquellas son irrenunciables y ejercidas por los órganos administrativos que la tengan atribuida como propia, salvo los casos de delegación, sustitución o avocación previstos por las leyes. 
En ese sentido, entendió, que correspondía la delegación expresa de dicha facultad, toda vez que la misma ya había sido asignada a la Dirección Provincial de Ordenamiento Urbano y Territorial por medio del Decreto $N^{\circ} 35 / 18$.

Por último, cabe mencionar que la medida fue dictada en ejercicio del artículo 11 de la Ley $\mathrm{N}^{\mathrm{0}} 14.989^{39}$.

d) Decreto $N^{o}$ 210/19: en este último decreto en análisis, se delegan en el entonces Ministerio de Economía las operaciones de crédito público a realizar en el ejercicio 2019, en el marco de las autorizaciones otorgadas por los artículos $1^{\circ}$ y $4^{\circ}$ de la Ley $\mathrm{N}^{\mathrm{o}} 15.077,64$ de la Ley $\mathrm{N}^{\mathrm{o}} 13.767$ y 34 de la Ley $\mathrm{N}^{\circ} 13.403$, incorporado a la Ley $\mathrm{N}^{\circ} 10.189$.

En síntesis, lo que aquí se delega es la facultad -propia de la máxima autoridad del Poder Ejecutivo- de emitir títulos de deuda pública a realizar en los mercados de capitales y/o toda otra operación de crédito público en el ejercicio 2019, incluyendo la determinación de los términos y condiciones financieras convenientes en cada oportunidad de acuerdo con la operación de crédito público que se trate, la aprobación de la operatoria y los documentos relacionados, y de aquellos procedimientos de selección y contrataciones que resultaren necesarias a efectos de la implementación de dichas operaciones.

Esta medida fue dictada por la ex Gobernadora en ejercicio de las atribuciones conferidas por los artículos 144 -proemio- de la Constitución de la Provincia de Buenos Aires, las

39 ARTíCULO 110: Facultar al Gobernador a delegar en los Ministros Secretarios, en los Secretarios de Estado, Oficiales Mayores o funcionarios u organismos que en cada caso determine, las facultades relacionadas con las materias que le competen, de acuerdo con lo que se determine expresa y taxativamente por decreto. Solo podrán delegarse las atribuciones que se reciban por delegación, cuando ello esté autorizado en la norma delegante.

La delegación deberá precisar expresamente las funciones y materias sobre las que verse, el Ministro, Secretario de Estado u Oficiales Mayores o funcionarios que en cada caso se determine al que se delegan las facultades y en su caso, el término de vigencia.

Asimismo, los Ministros Secretarios y los Secretarios podrán delegar la resolución de asuntos relativos al régimen económico y administrativo de sus respectivas carteras, en los funcionarios que determinen y conforme con la organización de cada área. 
Leyes $\mathrm{N}^{\circ} 15.077 \mathrm{~N}^{\circ} 13.767, \mathrm{~N}^{\circ} 14.989$ y $\mathrm{N}^{\circ} 10.189$ y el Decreto No $3260 / 08$;

II.2.8. Decretos tendientes a encomendar la atención del despacho de los asuntos del Poder Ejecutivo

En el 2019, al igual que en el año anterior, hubo un (1) solo decreto referido a la temática a analizar. Así, en uso de las atribuciones conferidas por el artículo 124 de la Constitución de la Provincia de Buenos Aires, la entonces Gobernadora encomendó, por el lapso comprendido entre los días 5 y 9 de junio, la atención del despacho de los asuntos de la competencia del Poder Ejecutivo al ex Vicegobernador, mediante el Decreto No 667/19, justificando su ausencia en una inhabilidad temporaria.

\section{II.2.9. Decretos referidos a convenios}

En el año 2019 se dictaron veintiocho (28) decretos referidos a convenios, incluyendo aprobaciones, adendas, prórrogas y ampliaciones, lo que representa una reducción del cincuenta y cuatro con ochenta y cuatro por ciento $(54,84 \%)$ con respecto del año 2018, que ascendieron a sesenta y dos (62).

El impulso del expediente se distribuyó por jurisdicción, por organismos descentralizados y por secretarías del Poder Ejecutivo del siguiente modo: cuatro (4) por el Ministerio de Salud; cinco (5) Ministerio de Infraestructura y Servicios Públicos; cuatro (4) por el Ministerio de Ciencia, Tecnología e Innovación; dos (2) por la Secretaría de Derechos Humanos; dos (2) por el Instituto Provincial de Lotería y Casinos; uno (1) por el Ministerio de Desarrollo Social; uno (1) por la Secretaría Legal y Técnica; uno (1) por el Ministerio de Justicia; uno (1) por la Autoridad del Agua; uno (1) por la Dirección General de Cultura y Educación; y uno (1) por el Ministerio de Jefatura de Gabinete de Ministros.

Cabe destacar que se han registrado cinco (5) decretos cuyo exordio no informa si los mismos tramitaron por expediente 
administrativo. Se trata de los Decretos $N^{\circ} 581 / 19$, $N^{\circ} 1400 / 19$, $\mathrm{N}^{\circ} 1530 / 19, \mathrm{~N}^{\circ} 1531 / 19$ y No $1696 / 19$. Los cuatro (4) primeros fueron dictados en uso de las atribuciones conferidas por el artículo 144 -proemio- de la Constitución de la Provincia de Buenos Aires; todos ellos referenciando en la parte considerativa las competencias del Ministerio de Economía asignadas por el artículo 19 de la Ley de Ministerios $\mathrm{N}^{\circ}$ 14.989. Por los citados decretos se aprobaron los Convenios $\mathrm{N}^{\circ} 998$ y No 1007 , suscriptos el 3 de mayo de 2019 y el 30 octubre de 2019, respectivamente, entre la provincia de Buenos Aires y el Estado Nacional; No 1008, suscripto el 24 de octubre de 2019, entre la provincia de Buenos Aires y la Administración Nacional de la Seguridad Social (ANSES); y No 1009, suscripto el 24 de octubre de 2019, entre la provincia de Buenos Aires y la Administración Nacional de la Seguridad Social (ANSES). En todos los casos, se autorizó al Ministerio de Economía a la realización de los actos tendientes a la correcta implementación de los convenios aprobados y el cumplimiento de los compromisos que de éstos surjan a cargo de la Provincia.

El quinto acto sin cita de expediente corresponde al Decreto $\mathrm{N}^{\mathrm{0}} 1696 / 19$, dictado en ejercicio de lo dispuesto por los artículos $1^{\circ}$ de la Ley $\mathrm{N}^{\circ} 15.077,19$ de la Ley $\mathrm{N}^{\circ} 14.989$ y las atribuciones conferidas por el artículo 144 -proemio- de la Constitución de la Provincia de Buenos Aires. Por él se aprobó el Convenio $\mathrm{N}^{\circ}$ 1010, suscripto el día 5 de diciembre de 2019 entre la provincia de Buenos Aires y el Fondo Fiduciario para el Desarrollo Provincial, a los fines de posibilitar su entrada en vigencia conforme lo requerido en el referido instrumento. Al igual que los cuatro decretos referidos previamente, se delegó en el Ministerio de Economía la realización de los actos tendientes a la correcta implementación del Convenio aprobado por el artículo primero y el cumplimiento de los compromisos que de éste surjan a cargo de la Provincia. 


\begin{tabular}{lc|}
\hline Órgano Promotor (Superior) & \# Decretos \\
\hline Ministerio de Salud & 4 \\
\hline Ministerio de Infraestructura y Servicios Públicos & 5 \\
Ministerio de Ciencia, Tecnología e Innovación & 4 \\
\hline Secretaría de Derechos Humanos & 2 \\
\hline Instituto Provincial de Lotería y Casinos & 2 \\
\hline Ministerio de Desarrollo Social & 1 \\
\hline Secretaría Legal y Técnica & 1 \\
\hline Ministerio de Justicia & 1 \\
\hline Autoridad del Agua & 1 \\
Dirección General de Cultura y Educación & 1 \\
Ministerio de Jefatura de Gabinete de Ministros & 1 \\
\hline Sin organismo promotor & 5 \\
\hline Total & $\mathbf{2 8}$ \\
\hline
\end{tabular}

Ilustración 25. Cantidad de decretos de Convenios por órgano promotor. Fuente: elaboración propia.

Continuando con la descripción, podemos hacer una primera clasificación de acuerdo a si los convenios en análisis tienen o no contenido económico. Los números que arroja dicha distinción son los siguientes:

i. Sin contenido económico: seis (6) convenios.

ii. Con contenido económico: veintidós (22) convenios.

i. En la primera categoría, agrupamos los convenios que, con distintas fórmulas, se refieren a acuerdos de transferencia, cooperación, colaboración, implementación, adhesión, desarrollo, participación, investigación, fortalecimiento, capacitación, promoción, investigación, etc.

Dentro de ella encontramos los decretos que enunciamos a continuación:

a) Decreto $\mathrm{N}^{\mathrm{o}} 18 / 19$, por el cual se aprobó el Convenio Marco de Cooperación suscripto entre la Oficina Anticorrupción del Ministerio de Justicia y Derechos Humanos de la Nación, la 
Oficina de Fortalecimiento Institucional del Ministerio de Justicia de la provincia de Buenos Aires y el Municipio de Ezeiza, con el objeto de colaborar recíprocamente y de participar conjuntamente en iniciativas, proyectos, programas y/o acciones para el análisis de temas inherentes a la implementación de políticas de transparencia y prevención de la corrupción.

b) Decreto $N^{\circ} 1289 / 19$, el cual aprobó el Acuerdo de Transferencia de jurisdicción del Servicio Público de Distribución de Energía Eléctrica a la Provincia de Buenos Aires y la Ciudad Autónoma de Buenos Aires, el Acuerdo de Implementación de la referida transferencia y el Acuerdo para el ejercicio conjunto de la Jurisdicción sobre el Servicio Público Metropolitano de Distribución de Energía Eléctrica, todo ello en el marco de la Ley $\mathrm{N}^{\mathrm{o}}$ 15.078 de la Legislatura de la provincia de Buenos Aires. La referida norma autorizó al Poder Ejecutivo a suscribir los instrumentos, dictar las normas y crear los organismos que resulten necesarios a fin de hacer efectiva la transferencia en cuestión por parte de la Nación, de la jurisdicción y competencia sobre el servicio de distribución de energía eléctrica a cargo de EDENOR y EDESUR.

Por otro lado, el referido decreto dejó sin efecto su similar $\mathrm{N}^{\circ} 992$ de fecha 26 de julio del 2019, que tuvo exactamente el mismo objeto. La diferencia es que este último, en su artículo $8^{\circ}$, disponía "Dar cuenta a la Honorable Legislatura de la provincia de Buenos Aires para su correspondiente ratificación legislativa", lo cual no fue previsto en el comentado Decreto $N^{\circ} 1289 / 19$.

c) Decreto $N^{\circ} 1368 / 19$, mediante el que se aprobó el Convenio celebrado entre la Dirección General de Cultura y Educación de la provincia de Buenos Aires y la Corporación Andina de Fomento (CAF), cuyo objeto fue establecer entre las partes una relación de colaboración, cooperación, coordinación y asistencia, en temáticas de interés común.

d) Decretos $\mathrm{N}^{\mathrm{o}} 1374 / 19$ y No $1375 / 19$, por los cuales se aprobaron los acuerdos internacionales de cooperación -ejecutivosdenominados Memorandos de entendimiento en el marco de la 
"Iniciativa Spotlight para la reducción del femicidio y eliminación de la violencia contra las mujeres y niñas en Argentina", como parte de una estrategia encaminada a concretar la igualdad de género y el empoderamiento de la mujer, en consonancia con la Agenda 2030 para el Desarrollo Sostenible.

Ambos decretos fueron impulsados por la entonces Secretaría de Derechos Humanos y dictados en el marco de las facultades otorgadas por el artículo 144 -proemio- de la Constitución de la Provincia de Buenos Aires.

El Decreto No 1374/19 fue suscripto con "ONU Mujeres", órgano subsidiario de las Naciones Unidas que tiene como mandato alcanzar la igualdad de género y el empoderamiento de las mujeres, reconociendo la importancia de colaborar y cooperar con socios para alcanzar su mandato y sus objetivos estratégicos. Por su parte, el Decreto No 1375/19 se celebró con el Programa de las Naciones Unidas para el Desarrollo (PNUD), representado por PNUD Argentina, en búsqueda de reforzar sus actividades en el ámbito del desarrollo para prevenir, abordar y reducir las desigualdades, así como todo tipo de discriminación y violencia por razones de género, edad, orientación sexual, origen étnico, nacionalidad y discapacidad.

Los referidos Memorandos buscaron en el marco citado, alcanzar los objetivos comunes de las partes, definiendo actividades a llevar a cabo que redundaría en beneficio de los suscribientes, estableciendo la posibilidad de intercambiar documentación e información, con sujeción a las restricciones y arreglos que cualquiera de las partes pudiera requerir con el objeto de salvaguardar el carácter confidencial de los mismos y de realizar acuerdos posteriores que permitan implementar la ejecución de las actividades para alcanzar el fin propuesto. Asimismo, establecieron una duración inicial de dos (2) años a partir de la fecha de suscripción.

ii. En el segundo grupo -convenios con contenido económico-, hacemos referencia, a su vez, a dos (2) situaciones distintas; por un lado, los que tienen afectación presupuestaria 
directa (prevista en la parte dispositiva del decreto) y, por el otro, los que generan un compromiso económico sin impacto inmediato en el presupuesto del organismo.

Así, encontramos tres (3) decretos relativos a convenios con afectación presupuestaria, dictados en uso de las atribuciones conferidas por el artículo 144 -proemio- de la Constitución de la Provincia de Buenos Aires y de conformidad a los Niveles de Decisión y Cuadro de Competencia para los Procedimientos de Selección de Contratación de Bienes y Servicios, previsto en el Anexo II del Decreto Reglamentario de la Ley $\mathrm{N}^{\circ}$ 13.981. Con tal criterio encontramos uno (1) impulsado por el Ministerio de Salud -Decretos No 364/19-, uno (1) por el Ministerio de Jefatura de Gabinete de Ministros -Decreto No 443/19- y, el último, por el Instituto Provincial de Lotería y Casinos -Decreto No 452/19-.

Al respecto, cabe aclarar que el Decreto $N^{\circ} 364 / 19$ fue enmarcado en los artículos 18, apartado 2, inciso h) de la Ley $\mathrm{N}^{\mathrm{o}} 13.981$ y 11, apartado 3, punto I inciso e) del Anexo I de su Decreto Reglamentario -proveedor no inscripto en el Registro de Proveedores y Licitadores del Estado-.

El Decreto $N^{\circ} 443 / 19$, por su parte, corresponde a la ampliación y prórroga, en el marco de lo regulado por el artículo 7 inciso f) de la Ley $N^{o} 13.981$ y su Decreto Reglamentario $N^{o} 1300 / 16$, de la contratación directa enmarcada en los supuestos de urgencia y de inexistencia de sustituto conveniente, conforme lo prevé la mencionada Ley $\mathrm{N}^{\circ} 13.981$ en su artículo 18 inciso 2 apartados c) y d, que fuera aprobada por Decreto $\mathrm{N}^{\mathrm{o}} 166 / 17 \mathrm{E}$ y formalizada por convenio suscripto con fecha 16 de mayo de 2017, entre el Ministerio de Jefatura de Gabinete de Ministros y la ex empresa Ertach S.A. - Prima S.A. (UTE), actualmente Ertach S.A. - Cablevisión S.A. (UTE), mediante el cual se contrató el servicio de Transmisión de Datos necesarios para la Red Única Provincial de Comunicación de Datos (RUPCD).

El Decreto $\mathrm{N}^{\circ} 452 / 19$, a su turno, se enmarcó como contratación directa por excepción en los términos del artículo 18 inciso 2 apartado a) de la Ley $\mathrm{N}^{\mathrm{o}} 13.981$ y su reglamentación, 
a través de la cual se contrató la impresión gráfica de cartones de bingo a realizar por la Dirección Provincial de Impresiones y Digitalización del Estado.

Por su parte, el Decreto $N^{\circ} 400 / 19$, aprobó el Proyecto Programa de Naciones Unidas para el Desarrollo (PNUD) ARG/ 16/006 denominado "Apoyo al Plan estratégico para garantizar una vida sana y promover el bienestar de toda la población de la Provincia de Buenos Aires, en todas las etapas de su ciclo de vida (2016-2019)”, y por su artículo $2^{\circ}$ indicó las partidas por las cuales se hizo frente a las erogaciones.

Finalmente, dentro de esta categoría encontramos el Decreto $N^{\circ} 1435 / 19$, que aprobó la Revisión "D” del Proyecto ARG/15/002 del Programa de Naciones Unidas para el Desarrollo PNUD, denominado "Apoyo a la Implementación del Programa de Saneamiento Ambiental de la Cuenca del Río Reconquista” aprobado por el Decreto No 591/15. La referida Revisión tuvo como objetivo ampliar el presupuesto total en la suma de dólares cuatrocientos cincuenta y cinco mil quinientos setenta (USD 455.570) para poder llevar a cabo el Plan de Trabajo 2019.

Por último, relevamos los convenios con contenido económico sin afectación presupuestaria directa, a saber:

a) El Decreto $N^{\circ} 46 / 19$, convalidó la Resolución $N^{\circ} 42 / 17 \mathrm{E}$ del entonces Ministerio de Ciencia, Tecnología e Innovación, por la cual se aprobó el Documento Proyecto Programa de Naciones Unidas para el Desarrollo (PNUD) ARG 16024 denominado "Apoyo a las Políticas de Ciencia Tecnología e Innovación de la Provincia de Buenos Aires". El referido proyecto buscó fortalecer al Ministerio de Ciencia, Tecnología e Innovación y dotarlo de capacidades suficientes para ejecutar políticas en su materia que contribuyan a situar a la Provincia en una senda de desarrollo económico, social y cultural sostenible y equilibrado territorialmente

b) El Decreto No 102/19, aprobó el Convenio entre la Secretaría de Gestión del Transporte del Ministerio de Transporte 
de la Nación y la Subsecretaría de Transporte del Ministerio de Infraestructura y Servicios Públicos de la provincia de Buenos Aires a los fines de constituir a la provincia de Buenos Aires como beneficiaria del Fondo de Compensación al transporte público de pasajeros por automotor urbano del interior del país, creado por el artículo 125 de la Ley Nacional No 27.467.

c) El Decreto $\mathrm{N}^{\circ} 116 / 19$, aprobó la Addenda al Convenio Marco de Participación en el Programa de Desarrollo de Seguros Públicos Provinciales de Salud aprobado por Decreto No 339/14, celebrada entre el Ministerio de Salud de la Nación y la provincia de Buenos Aires, que tuvo por objeto incorporar a hombres de 20 a 64 años como población objetivo del programa SUMAR.

d) El Decreto $N^{\circ} 133 / 2019$, aprobó la Addenda al Convenio Marco de Participación en el Programa de Desarrollo de Seguros Públicos Provinciales de Salud - Programa SUMAR aprobado por Decreto No 339/14, celebrada entre el Ministerio de Salud de la Nación y la Provincia de Buenos Aires con fecha 18 de abril de 2017, prorrogando la vigencia del Convenio Marco hasta el 31 de diciembre de 2018 o hasta la finalización de los recursos CP BIRF No 8062 y/o N $\mathrm{N}^{\circ}$ 8516-AR.

e) El Decreto $N^{o} 184 / 19$, aprobó el Convenio de Cooperación suscripto entre el Ministerio de Ciencia, Tecnología e Innovación y la Fundación Latinoamericana Verde (LATAMVE), mediante el cual establecieron el alcance de la intervención del Ministerio, como aliado de difusión, de los "Premios Latinoamérica Verde".

f) El Decreto $N^{\circ} 365 / 19$, aprobó el Acuerdo Marco suscripto entre la Autoridad del Agua (ADA) y la Comisión Nacional de Actividades Espaciales (CONAE), mediante el cual las partes acordaron cooperar institucionalmente en el marco del Plan Espacial Nacional y del Proyecto Institucional "Implementación de Imágenes Satelitales de Alta Resolución para la Gestión de los Recursos Hídricos de la Provincia de Buenos Aires en Cumplimiento y Ejecución de las Misiones Encomendadas a la 
Autoridad del Agua por la Ley $\mathrm{N}^{\circ} 12.257$ y las Leyes que la modifiquen, sustituyan o reemplacen", impulsando el desarrollo, en el país, de la capacidad para transformar la información espacial en productos de alto valor agregado transferible a distintos sectores de la sociedad.

g) El Decreto $\mathrm{N}^{\circ} 399 / 19$, aprobó la Adenda I al Convenio de Colaboración Técnica y Cooperación Institucional celebrado entre el Estado Nacional y la provincia de Buenos Aires aprobado por el Decreto $\mathrm{N}^{\mathrm{o}} 1813 / 18$, cuyo objeto se centraba en establecer un procedimiento eficaz de liquidación y pago de compensaciones tarifarias, con destino a las empresas prestatarias de transporte público de pasajeros por automotor de tipos urbano, provincial y municipal del Área Metropolitana de Buenos Aires, conforme el artículo $2^{\circ}$ de la Ley $\mathrm{N}^{\mathrm{o}} 25.031$.

h) El Decreto $N^{\circ} 498 / 19$ aprobó un acuerdo específico entre la Comisión de Investigaciones Científicas, el Consejo Nacional de Investigaciones Científicas y Técnicas y la Universidad Nacional de La Plata, con la finalidad de conformar el Observatorio Medioambiental de La Plata, cuyo objetivo principal es la integración de la información básica, el análisis permanente vinculado al medio ambiente y el aporte de los resultados para la prevención y solución por parte de las autoridades responsables.

i) El Decreto $N^{\circ} 585 / 19$, aprobó el Convenio Marco suscripto entre el Ministerio de Ciencia, Tecnología e Innovación de la provincia de Buenos Aires y la Comisión Nacional de Energía Atómica (CNEA), con el propósito de intercambiar experiencias de gestión, innovación y modernización tecnológica en el sector público, establecer relaciones formales de cooperación, en lo que se refiere a la realización de estudios y trabajos en áreas de interés conjunto, colaboración en el intercambio de información técnica y trabajo conjunto, en materia de formación de recursos humanos.

j) El Decreto $N^{o} 1241 / 19$, aprobó el Convenio celebrado entre el Instituto Provincial de Lotería y Casinos de la provincia de Buenos Aires y la Caja Popular de Ahorros de la Provincia de 
Tucumán, referente a la comercialización en la jurisdicción de la provincia de Buenos Aires de la variante de juego denominada "Tele-Kino", estableciendo porcentajes de distribución de la utilidad que surja de la recaudación bruta para el Fondo Provincial de Trasplante de Órganos y el Fondo Provincial de Juegos.

k) El Decreto $N^{o} 1315 / 19$, aprobó el Convenio Marco de Adhesión al Programa de Desarrollo de Áreas Metropolitanas del Interior II (DAMI II) suscripto entre el Ministerio del Interior, Obras Públicas y Vivienda de la Nación, la provincia de Buenos Aires y la Ciudad Autónoma de Buenos Aires, con financiamiento mediante Contrato de Préstamo BID No 3780/ OC-AR entre la República Argentina y el Banco Interamericano de Desarrollo (BID), asignándose a la Provincia y a la Ciudad en forma conjunta la cantidad de dólares estadounidenses veinte millones (U\$S 20.000.000).

1) El Decreto $N^{o} 1434 / 19$, aprobó un Convenio de Cooperación suscripto entre la Secretaría Nacional de Niñez, Adolescencia y Familia del Ministerio de Salud y Desarrollo Social de la Nación y el Gobierno de la provincia de Buenos Aires, a través del Ministerio de Desarrollo Social, el Ministerio de Salud y la Dirección General de Cultura y Educación, que tuvo por finalidad entablar acciones de cooperación y trabajo conjunto que permitan el alcance de los resultados esperados del "Plan Nacional de Prevención y Reducción del Embarazo No Intencional en la Adolescencia”.

\section{II.2.10. Decretos de resolución de recursos administrativos}

i. Durante 2019, se dictaron ocho (8) decretos que dieron tratamiento a recursos administrativos en el marco del DecretoLey $\mathrm{N}^{\circ} 7647 / 70$ contra resoluciones finales, referidos cinco (5) de ellos a recursos de revocatoria, dos (2) a recursos jerárquicos y un (1) recurso de apelación. ${ }^{40}$ Dentro de ellos, el último men-

40 El sistema recursivo provincial encuentra cabida en el Decreto-Ley N ${ }^{0} 7647 / 70$ en los artículos 86 (decisiones recurribles), 87 (cuestiones irrecurribles como dictámenes, vistas, 
cionado reviste interés especial, atento que fue interpuesto por el Fiscal de Estado.

Cabe destacar que, al igual que en 2018, todos los recursos resueltos por la Gobernadora saliente durante 2019, fueron desfavorables al/ a la recurrente.

Asimismo, se advierte que, si bien hubo un incremento en la cantidad de recursos resueltos, en 2018 fueron cinco (5) decretos y en 2019 hubo ocho (8) actos dictados referidos al tema, lo cierto es que continúa siendo un número reducido.

Diversas causas podrían explicar la referida situación: por un lado, la cantidad de actos administrativos cuya decisión final corresponde a los/as ministros/as (competencia propia); y por otro lado, la delegación en los/as señores/as ministros/as, secretarios/as del Poder Ejecutivo, titulares de los Organismos de la Constitución y Asesor General de Gobierno, de la resolución del recurso jerárquico previsto en el artículo 100 del Decreto-Ley No $7647 / 70$ (art. $1^{\circ}$ inc. 18, Decreto $N^{\circ}$ 272/17E).

Finalmente, nos parece importante destacar que sólo tres (3) de los decretos indican en su parte considerativa la fecha de interposición de los recursos, dato necesario para conocer si la Administración se expidió dentro los plazos legales.

Cabe recordar que el régimen establece que el órgano debe resolver dentro de los cinco (5) días el recurso de revocatoria

entre otros), 88 (toda impugnación debe ser canalizada por la Administración con independencia de la denominación dad por el recurrente), 89 al 91 (recurso de revocatoria y jerárquico en subsidio), 92 y 93 (recurso jerárquico), 94 (apelación -denominación dada al recurso contra la decisión de un ente autárquica que no deje expedita la vía contenciosa administrativa-); 95 (recursos contra actos generales) y 96 (recursos contra actos de oficio).

Por su parte, el artículo 97 determina las exclusiones; el 98 los efectos de la interposición del recurso; y los artículos 99 a 101 el trámite y decisión. Finalmente, el artículo 102 dispone que los recursos reglados en el capítulo en cuestión, rigen para los agentes administrativos, por la relación de empleo público, supletoriamente de los establecidos en la legislación específica.

Su importancia radica en la relación de lo actuado con el artículo 166, último párrafo, de la Constitución Provincial y el Código Contencioso Administrativo (Ley Nº 12.008 y modificatorias), en relación al "agotamiento de la vía". 
(art. 77 inc. f, Decreto-Ley $\mathrm{N}^{\circ} 7647 / 70$ ), diez (10) días respecto del jerárquico (arts. 92 y 77 inc. g, Decreto-Ley $N^{\circ}$ 7647/70) y treinta (30) días en el caso de la apelación (art. 77 inc. g in fine, Decreto-Ley $\mathrm{N}^{\mathrm{o}}$ 7647/70).

En los tres (3) supuestos señalados se excedió ampliamente el plazo previsto legalmente. Así, tratándose en todos los casos de recurso de revocatoria, entre la interposición de las piezas recursivas que dieron origen a los Decretos $\mathrm{N}^{\circ} 1711 / 19^{41} \mathrm{y}$ $\mathrm{N}^{\mathrm{o}} 1712 / 19^{42}$ y su dictado, transcurrieron trescientos treinta y cinco (335) y trescientos treinta y un (331) días, respectivamente, y en el caso del Decreto $\mathrm{N}^{\mathrm{0}} 608 / 19^{43}$, el plazo fue de mil cuatrocientos noventa y dos días (1492).

ii. A continuación, pasaremos revista a los distintos decretos que resolvieron recursos:

a) El recurso de apelación resuelto mediante Decreto $\mathrm{N}^{\mathrm{o}} \mathbf{1 0 6 / 1 9}$, fue interpuesto por el Fiscal de Estado contra un acto considerado ilegítimo, mediante el cual se resolvió acordar el beneficio de jubilación ordinaria a L.A.M., a partir del 2 de junio de 2015, por encontrarse reunidos los requisitos establecidos en el Decreto-Ley No 9650/80 (T.O. 1994).

Contra dicho acto administrativo, se alzó el Fiscal cuestionando la prueba ofrecida por el interesado en el expediente de reconocimiento de servicios tramitado ante la ANSES. Sostuvo que los años de aportes certificados no resultaban ser fehacientes y que importaban una mera compra de servicios para obtener una prestación previsional.

El decreto no hizo lugar a lo impugnado, sosteniendo que en función del régimen de reciprocidad jubilatorio establecido por Decreto $\mathrm{N}^{\circ} 9316 / 46$ y ratificado por Ley $\mathrm{N}^{\circ} 9.820$, el

\footnotetext{
41 El recurso se interpuso el 4 de enero de 2019 y el decreto se dictó el 5 de diciembre del mismo año.

42 El recurso se interpuso el 8 de enero de 2019 y el decreto se dictó el 5 de diciembre del mismo año.

43 El recurso se interpuso el 30 de abril de 2015 y el decreto se dictó el 31 de mayo de 2019.
} 
reconocimiento por parte de la ANSES de las tareas autónomas cuya consideración se cuestionó, con la posterior calificación requerida por la normativa de aplicación para su cómputo, no es revisable en la instancia provincial.

En función de lo expuesto, la ex Gobernadora decidió rechazar el recurso de apelación interpuesto por el Fiscal de Estado contra la Resolución del Instituto de Previsión Social $\mathrm{N}^{\mathrm{o}} 868.360$ del 21 de junio de 2017, por los motivos expuestos en la parte considerativa.

Por último, en lo que aquí importa, el decreto presenta la particularidad de que la resolución es cuestionada por el Fiscal de Estado. Este singular modo de actuación, como refiere Tribiño, ${ }^{44}$ tiene su antecedente más remoto en la Ley $\mathrm{N}^{\circ} 733$ de 1871. En la actualidad, sólo se encuentra establecida legalmente en las tramitaciones previsionales -Instituto de Previsión Social y Caja de Retiros, Jubilaciones y Pensiones de la Policía-; limitada, a aquellos supuestos en que la decisión administrativa no revista el carácter de definitiva -no cause "estado"-, lo que impide su cuestionamiento en el fuero contencioso administrativo local.

No obstante, atento que el Fiscal de Estado tiene a su cargo el control de los actos administrativos alcanzados por el artículo 38 de la Ley orgánica del órgano constitucional, le es posible al Fiscal cuestionar la legitimidad de éstos en otros casos, en especial cuando las decisiones cuestionadas provengan de órganos inferiores al Poder Ejecutivo.

b) Por su parte, a través del Decreto No $501 / 19$, la entonces jefa de la Administración Pública provincial decidió rechazar el recurso jerárquico planteado por el Presidente de la Cooperativa de Agua Potable y Otros Servicios Públicos de Melchor Romero Limitada contra la Resolución del Ministro de Producción $\mathrm{N}^{\mathrm{o}} 104 / 17$, por no haber aportado, a su entender, nuevos

\footnotetext{
44 Tribiño, Carlos R., El Fiscal de Estado. La representación judicial del Estado y el control de la actividad administrativa, Buenos Aires, Editorial Ábaco, Buenos Aires, p. 109.
} 
elementos de juicio o hechos que permitieran enervar el acto atacado, quedando, de esta forma, agotada la vía administrativa. ${ }^{45}$

Contra la referida resolución, el Presidente de la Cooperativa interpuso recurso de revocatoria con jerárquico en subsidio. Por Resolución Ministerial $\mathrm{N}^{\circ} 175 / 18$, se resolvió rechazar el recurso de revocatoria planteado y elevar el jerárquico en subsidio a la entonces Gobernadora a los fines de someterlo a su consideración. Habiéndose notificado dicha resolución, el recurrente hizo uso de su derecho de ampliar los fundamentos de la queja, en los términos del artículo 91 del Decreto-Ley $N^{\circ}$ 7647/70.

Al respecto, la ex mandataria sostuvo que "no obstante encontrarse fundado, el recurrente no aporta nuevos elementos

45 Cabe destacar que mediante el acto atacado, se declaró irregular e ineficaz a los efectos administrativos, la convocatoria y posterior realización de la asamblea ordinaria fijada para el 30 de abril de 2016 por el Consejo de Administración de la Cooperativa en cuestión; al tiempo que se declararon irregulares e ineficaces todas las incorporaciones de aspirantes defectuosamente admitidos desde el $1^{\circ}$ de diciembre de 2015 por el Consejo de Administración, así como todos los asientos y registraciones efectuadas en el libro Registro de Asociados $\mathrm{N}^{0} 2$ de la Cooperativa. Además, se intimó a la entidad para que proceda a efectuar el trámite de rúbrica del Libro Registro de Asociados N 3, y para que proceda a efectuar los asientos correspondientes a fin de subsanar irregularidades, debiendo exhibirlo con posterioridad, ante la Dirección de Fiscalización y Contralor; se le requirió a dicho organismo se expida acerca del cumplimiento de la Resolución INAC № 250/82 y la Resolución INAES Nº 5586/12, y del saneamiento de las demás irregularidades corroboradas en las actuaciones, observando el debido proceso y el principio de contradicción entre las partes; se instruyó a la Dirección de Registro, Archivo y Asuntos Legales, a efectos de que proceda a intervenir el Libro Registro de Asociados $N^{0} 2$, inutilizándolo en todas sus fojas. En igual sentido, se intimó a la Cooperativa para que, acredite la convocatoria a Asamblea General Ordinaria, bajo apercibimiento de proceder según lo dispuesto por los artículos 100 y 101 del Decreto-Ley N N 20.337/73, y a incluir en el orden del día un punto referente a la íntegra lectura de la Resolución N 104/17. Además, se hizo saber al Consejo de Administración de la Cooperativa referida, que en la asamblea ordinaria a convocar sólo podrían participar los asociados debidamente incorporados hasta el 30 de noviembre de 2015, y se instruyó a la Dirección de Fiscalización y Contralor, a fin de que destaque veedores para la fiscalización del acto al que se refiere el artículo $9^{\circ}$ de la mentada Resolución, quienes debían elaborar el informe correspondiente. Finalmente, se intimó a la entidad de marras, para que acredite la convocatoria a asamblea a efectos de considerar la reforma del estatuto social en lo concerniente al valor de la cuota social y se dio intervención a la Dirección Provincial de Educación, Promoción y Desarrollo para que, proyecte jornadas obligatorias de educación y capacitación, destinadas a la masa de asociados de la Cooperativa. 
de juicio que ameriten cambiar el criterio expuesto en el acto impugnado" y, sin más, resolvió rechazar el recurso comentado.

c) El Decreto No 608/19 resolvió sobre la presentación de un agente de Fiscalía de Estado mediante la cual solicitó el pago de la bonificación establecida en el artículo $4^{\circ}$ del Decreto $\mathrm{N}^{\mathrm{o}} 3319 / 09^{46}$, a partir de su entrada en vigencia y hasta la notificación del Decreto $N^{\circ} 1361 / 13$, más la actualización monetaria e intereses hasta la fecha del efectivo pago. ${ }^{47}$

En primer lugar, la Administración, invocando el principio de formalismo moderado, analizó la presentación como recurso de revocatoria contra el Decreto No 3319/09 (artículo 88 del Decreto-Ley $\mathrm{N}^{\circ}$ 7647/70). Sobre el particular, señala el acto en estudio que aquel devino extemporáneo, toda vez que el interesado se notificó del Decreto No $3319 / 09$ el $1^{\circ}$ de julio de 2009 y dedujo la impugnación el 30 de abril de 2015.

A continuación, indicó que tampoco podía prosperar la petición como denuncia de ilegitimidad, ya que, a criterio de la autoridad, no obraban en el expediente constancias de que el agente se hubiese desempeñado con anterioridad en la condición invocada.

En base a lo expuesto, la ex Gobernadora rechazó por extemporáneo el recurso de revocatoria deducido contra el

46 Cabe tener presente que tanto el Decreto $N^{0} 3319 / 09$, como todos aquellos que en forma nominada otorgaban bonificaciones al personal que desempeñe funciones de chofer, se encuentran derogados en virtud del artículo 10 del Decreto $N^{0} 588 / 19$, que unifica el tratamiento laboral de este rubro.

47 Cabe destacar que el Decreto N³319/09 estableció, para los/as agentes que se desempeñaban como choferes en la Fiscalía de Estado, bajo el régimen de Planta Permanente y de Planta Temporaria de la Ley $N^{0} 10.430$ y modificatorias, enumerados en su Anexo A una bonificación remunerativa no bonificable, calculada conforme su artículo $3^{\circ}$. Asimismo, para aquellos choferes con dedicación plena a la labor listados en el Anexo B, se adicionaba otra bonificación remunerativa no bonificable, conforme la escala prevista en el artículo $4^{\circ}$.

El recurrente se encontraba contemplado en el Anexo A del referido decreto, mas no en el Anexo $B$, en el cual fue incluido recién cuatro años después, mediante Decreto N 1361/13.

Conforme surge de la parte considerativa del acto administrativo comentado, el agente fundó su reclamo en la circunstancia de encontrarse en igual situación laboral que los/as agentes incluidos/as oportunamente en el Anexo B del citado Decreto №3319/09. 
Decreto No 3319/09 y lo desestimó como denuncia de ilegitimidad en los términos del artículo 74 del Decreto-Ley $N^{\circ} 7647 / 70$.

d) Mediante Decreto $N^{\circ} 717 / 19$, la entonces Gobernadora rechazó los recursos de revocatoria interpuestos por dos agentes del Departamento Desarrollo y Mantenimiento dependiente de la Dirección de Computación y Organización del Instituto de Previsión Social, contra el Decreto No 1670/13. Al respecto, corresponde señalar que por este acto se aprobó el plantel básico nominado e innominado de la referida dirección, de conformidad con la Disposición $N^{\circ}$ 2812/09 de la entonces Dirección Provincial de Personal y se otorgó a los/as agentes comprendidos/as, una bonificación equivalente a la diferencia salarial existente entre la categoría de revista, agrupamiento y especialidad de cada uno y las categorías que en cada caso se establecen en él, conforme al acta paritaria $N^{\circ} 6 / 12$, por la cual se acordó la jerarquización de los roles informáticos asignados.

Para fundamentar dicha decisión, puso de manifiesto que toda modificación en la situación de revista de los/as agentes de la administración pública provincial, debe respetar las pautas establecidas en el régimen estatutario de pertenencia, que en el caso era la Ley $\mathrm{N}^{\mathrm{O}} 10.430$ (texto ordenado por Decreto N $^{\circ}$ 1869/96) y su Decreto Reglamentario No 4161/96. Agregó que los artículos 155 y siguientes de la ley citada establecen el régimen de ascensos, promociones y cambios de agrupamiento, y estas circunstancias están supeditadas no sólo a la existencia de vacantes en el plantel básico respectivo, sino también al cumplimiento de los requisitos exigidos para el cargo a cubrir y a la calificación, antecedentes, méritos y capacitación del/ de la agente, razón por la cual todo cambio en la situación de revista debe adecuarse y ser consecuencia de la aplicación del régimen legal vigente. Asimismo, sostuvo que "el derecho a progresar en la carrera administrativa no justifica evadir los procedimientos establecidos al efecto en la Ley $\mathrm{N}^{\circ} 10.430$, ni la obtención de categorías determinadas sobre la base exclusiva de la capacitación y con total prescindencia de las vacantes existentes, de 
los concursos y selección que se realicen al efecto y las tareas efectivamente asignadas y cumplidas por los agentes."

Finalmente, aseguró que los recurrentes no aportaron pruebas que, a su criterio, ameritaran la revisión de las certificaciones oportunamente expedidas por quien se desempeñaba como autoridad, razón por la cual no advirtió vulneración alguna de los derechos de los reclamantes, por lo que los recursos resultaron, a su entender, improcedentes.

e) Por su parte, el Decreto $N^{\circ} 1286 / 19$, resolvió el recurso de revocatoria con jerárquico en subsidio interpuesto por Federico Ebarlin, agente del Hospital Interzonal Especializado Neuropsiquiátrico de Agudos y Crónicos "Dr. Alejandro Korn" de Melchor Romero, contra el Decreto $N^{0} 38 / 17$, por el cual se aceptó su renuncia al cargo de Director Asociado del referido establecimiento, a partir del $1^{\circ}$ de mayo de 2016 , y se lo reintegró a su cargo de revista como contador público asistente, con un régimen de treinta y seis (36) horas semanales de labor. El recurrente se agravió del régimen horario referido, postulando que le correspondía reintegrarse a un régimen de cuarenta y ocho (48) horas semanales de labor y, en sustento de esa pretensión, invocó el artículo 17 del Decreto $N^{\circ} 3589 / 91$ y el Decreto $N^{\circ} 40 / 05$, por el cual se reservó su cargo de revista con el régimen horario reclamado.

El Poder Ejecutivo rechazó el recurso, por considerar que, si bien el artículo 17 del Decreto $N^{\circ} 3589 / 91$, reglamentario de la Ley $\mathrm{N}^{\circ} 10.471$, dispone que el agente que cesara en cualquiera de las funciones indicadas por el artículo $8^{\circ} \mathrm{y}$ hubiese desarrollado las mismas con extensión horaria y bloqueo de título, retomará el cargo de la planta en que reviste, manteniendo dichos beneficios, ello es así siempre y cuando las funciones del profesional o el establecimiento en que presta servicios no estén afectados al régimen de insalubridad, de conformidad con lo dispuesto en la Ley Nacional No 11.544 -y en los decretos Nros. 2198/01 y 2868/02, que receptaron la temática en la Provincia-, como ocurrió, según señala el acto en cuestión, en el caso de 
autos. Asimismo, el rechazo del recurso se fundó en que, sin bien al momento de su designación como director asociado, por Decreto $\mathrm{N}^{\circ} 40 / 05$, el recurrente reservó un cargo de la planta permanente de la Ley $\mathrm{N}^{\circ} 10.430$, con un régimen de cuarenta y ocho (48) horas semanales de labor, con posterioridad, por Resolución 11112 N $^{\circ}$ 1075/11 fue reubicado en un cargo de la planta permanente de la Ley $\mathrm{N}^{\mathrm{o}} 10.471$, de conformidad con lo dispuesto en la Ley $\mathrm{N}^{\circ}$ 14.061, y se transformó el régimen horario de su cargo de revista en uno de treinta y seis (36) horas semanales de labor.

f) Los Decretos $\mathrm{N}^{\circ} 1711 / 19$ y $\mathrm{N}^{\mathrm{o}} 1712 / 19$ resolvieron los recursos de revocatoria interpuestos por la firma Apparel Argentina S.A. y Ana Mercedes Bozzarelli, titular de la firma "Asepsia Lavandería Industrial", respectivamente, contra el Decreto $\mathrm{N}^{\mathrm{0}} 1753 / 18$.

Mediante el acto atacado se aprobó la Licitación Pública $\mathrm{N}^{\mathrm{o}}$ 102-0071-LPU18 para la contratación del servicio de lavadero externo con/sin provisión de ropa con destino a diversos hospitales provinciales y unidades de pronta atención dependientes del Ministerio de Salud de la Provincia; resultando adjudicatarias las firmas Sistema Burbujas S.R.L., Lavadero Berazategui de Juan Palermo y Néstor Silvio Palermo, Lavadero Banfield S.A., Tex Care Argentina S.A., Lavadero El Lucero S.R.L y Lavadero Anca S.A. Asimismo, se rechazaron las impugnaciones efectuadas por las firmas Bozzarelli Ana Mercedes y Apparel Argentina S.A. al Dictamen de Preadjudicación de ofertas. Notificado el Decreto $N^{o}$ 1753/18 a los oferentes el día 27 de diciembre de 2018, las empresas interpusieron contra él, en forma temporánea, sendos recursos de revocatoria.

A través de su presentación de fecha 4 de enero de 2019, la firma Apparel Argentina S.A. solicitó la nulidad del acto administrativo, por entender que conculcaba normas de orden constitucional. Al mismo tiempo, la recurrente adujo haber sido víctima de una falsa denuncia por parte de la Federación de Cámaras de Lavanderías, Limpierías y Afines de la República 
Argentina (FEDELARA), a través de la cual, según alegó, se realizaron acuerdos de precios, afectando de esta forma la Ley de Defensa de la Competencia.

Conforme surge de la parte considerativa del acto impugnado, el recurso interpuesto adolece de los requisitos de admisibilidad establecidos en el artículo 89 del Decreto-Ley $\mathrm{N}^{\circ} 7647 / 70$, en tanto no fue interpuesto ante autoridad competente. Sin perjuicio de ello, en virtud del principio de informalismo fue declarado procedente.

A pesar de ello, el Decreto $\mathrm{N}^{\circ} 1711 / 19$ rechazó el recurso de revocatoria, señalando que "los argumentos vertidos no difieren de los que fueran manifestados oportunamente en la impugnación al Dictamen de Preadjudicación de ofertas y por lo tanto no se encuentran elementos que permitan modificar el criterio tenido en cuenta para proceder a la impugnación del acto administrativo aquí recurrido, y careciendo este último de vicio alguno en sus elementos esenciales que pudieran determinar su revocación parcial o total, corresponde desestimar el recurso de revocatoria interpuesto".

Por su parte, la firma "Asepsia Lavandería Industrial", a través de su titular, Ana Mercedes Bozzarelli, presentó su pieza recursiva el 8 de enero de 2019, mediante la cual se agravió de la afectación al debido proceso por no respetarse, a su entender en forma injustificada, el plazo de cinco (5) días previsto en el artículo 20, apartado $2^{\circ}$ del Anexo I del Decreto $N^{\circ} 1300 / 16$, vigente al momento de dictarse acto atacado, dado que la apertura de ofertas acaeció el día 28 de junio de 2018 y la Comisión Asesora de Preadjudicación produjo su dictamen con fecha 23 de julio de 2018. Asimismo, denunció incumplimiento de los deberes de funcionario público. ${ }^{48}$

48 Cabe destacar que la Comisión Asesora de Preadjudicación, en el referido dictamen recomendó rechazar la oferta de la recurrente por encontrarse bajo una suspensión en el Registro Provincial de Lavaderos Industriales de Ropa y Transporte de Ropa dispuesta por el Organismo Provincial para el Desarrollo Sostenible (OPDS) mediante Disposición $N^{0}$ 124/18 de fecha 17 de julio de 2018. Al presentar su queja, en aquella oportunidad, la 
Sobre la impugnación, la entonces titular del Poder Ejecutivo consideró que los argumentos vertidos no diferían de los que fueran manifestados oportunamente en la impugnación al Dictamen de Preadjudicación de ofertas y por lo tanto no se encontraban, a su entender, elementos que permitieran modificar el criterio tenido en cuenta para proceder a la impugnación del acto administrativo recurrido, y careciendo, según su criterio, este último de vicio alguno en sus elementos esenciales que pudieran determinar su revocación parcial o total; mediante, Decreto $\mathrm{N}^{\circ} 1712 / 19$, rechazó el recurso de revocatoria interpuesto.

g) El Decreto $N^{\circ} 1734 / 19$ resolvió el recurso de revocatoria con jerárquico en subsidio interpuesto por la Cámara de Operadores de Establecimientos Externos del Puerto de San Nicolás (COEEPSA) contra la Resolución No 208/19 del Ministerio de Producción, mediante la cual se aprobaron las propuestas de designación de directores del Consorcio de Gestión del Puerto de San Nicolás, creado por Decreto No 96/19.

El acto en análisis señala en su parte considerativa que COEEPSA se presentó interponiendo recurso de revocatoria con jerárquico en subsidio contra la resolución mencionada, solicitando, asimismo, la suspensión de efectos del acto, manifestando diversos agravios, a saber: i) la falta de evaluación técnica y jurídica en las designaciones; ii) la ausencia de dictamen legal previo a la suscripción de la resolución; iii) la carencia de razonabilidad y legalidad de la misma; iv) la falta de representatividad de las entidades cuyos directores fueron designados; v) indicando que la Resolución atacada lesiona ilegítimamente los intereses de COEEPSA y el interés público comprometido, en tanto posee vicios en su causa, motivación y finalidad.

\footnotetext{
firma manifestó que la suspensión dispuesta por el OPDS tenía carácter provisorio y solicitó por ello se revea la desestimación recomendada en el dictamen; al tiempo que requirió que se excluyera a las firmas Tex Care SA y Lavadero Anca S.A., aduciendo infracciones a la normativa vigente aplicable al proceso licitatorio. Previo al dictado del Decreto N ${ }^{0}$ 1753/18 cuestionado, la Comisión se expidió sobre el reclamo, aconsejando su rechazo.
} 
Rechazado el recurso de revocatoria, como así también la solicitud de suspensión de sus efectos, a través de la Resolución No 304/19 del Ministerio de Producción; se procedió a intimar a la recurrente a los fines que proceda a ampliar o mejorar los fundamentos en los términos del artículo 91 del Decreto-Ley $\mathrm{N}^{\mathrm{7}} 7647 / 70$. Finalmente, se elevaron las actuaciones para la consideración del recurso jerárquico interpuesto en subsidio por parte de la ex Gobernadora, quien, alegando que en cuanto a la cuestión de fondo, el recurrente reiteró los fundamentos que motivaron el rechazo de la revocatoria, sin aportar nuevos elementos o argumentos que permitan modificar la decisión tomada, procedió a su rechazo.

\section{II.2.11. Decretos relativos a contrataciones públicas}

i. En referencia a las diligencias para licitar, contratar, adjudicar y gestionar la adquisición de bienes y servicios, se registran dieciséis (16) decretos, mediante los cuales el Sector Público provincial alcanzado por las disposiciones de la Ley $\mathrm{N}^{\mathrm{0}}$ 13.981, requirió la firma de la máxima autoridad Provincial.

Cabe señalar que de ellos, seis (6) han sido tramitados a través del Sistema de Compras Electrónicas de la Provincia de Buenos Aires, denominado "PBAC" 49 .

En cuanto a los procedimientos de selección elegidos, se registran seis (6) decretos que reflejan la elección del procedimiento licitatorio público ( $\mathrm{N}^{\circ}$ 668/19 y $\mathrm{N}^{\mathrm{o}} 1344 / 19$ refieren al mismo proceso contractual-, $\mathrm{N}^{\circ} 705 / 19$, $\mathrm{N}^{\circ} 817 / 19$, $\mathrm{N}^{\circ} 1235 / 19$ y No $\left.182 / 19\right)$ y tres (3) decretos que aprueban contrataciones directas excepcionales en razón del sujeto $\left(\mathrm{N}^{\circ} 15 / 19\right.$ modificado por el $\mathrm{N}^{\mathrm{o}} 246 / 19$ y No $145 / 19$ ).

\footnotetext{
49 El referido sistema fue habilitado el 3 de abril de 2017 por Resolución Conjunta № 20/17 del Ministerio de Jefatura de Gabinete de Ministros y N ${ }^{0}$ 92/17 del Contador General de la Provincia de Buenos Aires, y reglamentado su uso posteriormente, el 14 de junio de 2017 por la Resolución N ${ }^{0}$ 5/17 de la Contaduría General de la Provincia (Decretos N ${ }^{0}$ 1314/19, $N^{0} 668 / 19, N^{0} 1344 / 19, N^{0} 705 / 19, N^{0} 817 / 19$ y No 1235/19).
} 
Finalmente, encontramos siete (7) decretos que refieren a la etapa de ejecución contractual ( $\mathrm{N}^{\circ} 14 / 19, \mathrm{~N}^{\circ} 27 / 19$, $\mathrm{N}^{\circ} 848 / 19$, $\mathrm{N}^{\mathrm{o}} 1735 / 19$, No $214 / 19, \mathrm{~N}^{\circ} 453 / 19$ y No $\left.1314 / 19\right)$.

ii. Etapa de ejecución contractual.

a) Durante el ejercicio 2019 se han dictado cuatro (4) decretos, registrados bajo los números $\mathrm{N}^{\circ} 14 / 19$, No 27/19, No $848 / 19$ y $\mathrm{N}^{\circ} 1735 / 19$, mediante los cuales el Estado Provincial, a través de las carteras de Estado de Desarrollo Social, Agencia de Recaudación de la Provincia de Buenos Aires, Salud y Justicia, ha ejercido la prerrogativa de prorrogar sus contratos de conformidad con lo establecido por el artículo $7^{\circ}$, inciso $\mathrm{f}$, de la Ley $\mathrm{N}^{\mathrm{o}} 13.981$ y su Decreto Reglamentario $\mathrm{N}^{\mathrm{o}} 1.300 / 16$-entonces vigente-, los cuales implicaron el compromiso de erogación por las sumas, pesos un millón novecientos cincuenta y dos mil seiscientos dieciocho con cuarenta centavos $(\$ 1.952 .618,40)$, de pesos ciento cincuenta y seis millones seiscientos veintisiete mil quinientos $(\$ 156.627 .500,00)$ dólares estadounidenses tres millones quinientos veintiséis mil quinientos noventa $\mathrm{y}$ cuatro con veinte centavos (U\$S 3.526.594,20), pesos novecientos noventa millones cuatrocientos treinta y un mil setecientos noventa y cuatro con ochenta centavos ( $\$ 990.431 .794,80)$ y pesos ochocientos cincuenta y cuatro millones novecientos veinte mil trescientos veintitrés con sesenta y un centavos (\$854.920.323,61), respectivamente.

Los contratos prorrogados por los Decretos $N^{\circ} 14 / 19$, $\mathrm{N}^{\circ} 848 / 19 \mathrm{y} \mathrm{N}^{\circ} 1735 / 19$ fueron formalizados en el marco de las Licitaciones Públicas $\mathrm{N}^{\circ} 2 / 18, \mathrm{~N}^{\circ} 25 / 17$ y $\mathrm{N}^{\circ} 1 / 16$, por los cuales se contrató el Servicio de Organización de Eventos para el Programa "El Estado en tu Barrio", la prestación del servicio de elaboración y distribución de comidas, con destino al/ a la paciente internado/a, guarderías y personal autorizado de los hospitales y Unidades de Pronta Atención (UPA), dependientes del Ministerio de Salud y la prestación del servicio asistido de racionamiento para la cocción de alimentos destinados a la elaboración de desayuno, almuerzo, merienda y cena, para 
distintas Unidades Carcelarias y Establecimientos Penitenciarios, respectivamente.

Por otro lado, cabe señalar que el contrato prorrogado por el Decreto $\mathrm{N}^{\circ} 27 / 19$, ha sido formalizado en el marco de una Contratación Directa, encuadrada en las previsiones del artículo 18, inciso $2^{\circ}$, apartado d), de la Ley $\mathrm{N}^{\circ} 13.981$.

b) Asimismo, se ejerció la prerrogativa estatal de ampliación contractual a través de los Decretos $\mathrm{N}^{\circ}$ 214/19, $\mathrm{N}^{\circ} 453 / 19$ y $\mathrm{N}^{\mathrm{1}} 1314 / 19$, de conformidad con lo establecido por el artículo 7 , inciso b, de la Ley $\mathrm{N}^{\circ} 139.81$, los dos (2) primeros bajo el régimen del Decreto Reglamentario $\mathrm{N}^{\circ} 1300 / 16$ y el último del Decreto Reglamentario No 59/19 -actualmente vigente con modificaciones-.

El Decreto $N^{o}$ 214/19, fue impulsado por el Ministerio de Justicia para la aprobación de las ampliaciones de las órdenes de compra emitidas en el marco de la Licitación Pública $\mathrm{N}^{\mathrm{o}} 1 / 16$, tendiente a contratar la prestación del servicio asistido de racionamiento para la cocción de alimentos destinados a la elaboración de desayuno, almuerzo, merienda y cena, para las unidades penitenciarias $\mathrm{N}^{\circ} 28, \mathrm{~N}^{\circ} 35$ y $\mathrm{N}^{\circ} 51$ de Magdalena, por la suma de pesos cincuenta millones novecientos setenta y siete mil trescientos sesenta $(\$ 50.977 .360,00)$.

El Decreto $N^{0} 453 / 19$, impulsado por la Dirección General de Cultura y Educación, implicó la suma de pesos doscientos ochenta y nueve millones cuatrocientos cincuenta y tres mil seiscientos (\$289.453.600,00), destinada a la ampliación de la Orden de Compra Abierta emitida en el marco de la Licitación Pública $\mathrm{N}^{\mathrm{0}}$ 4/18, para la contratación de los servicios de alojamiento con media pensión y pensión completa, alquiler de salones equipados, traslados y catering para las jornadas de capacitación y encuentros destinados a alumnos/as y docentes de la provincia de Buenos Aires.

Finalmente, el Decreto $\mathrm{N}^{\circ} 1314 / 19$ refiere a la ampliación de la Orden de Compra emitida en el marco de la Licitación Pública No 4/19, Proceso de Compra No 445-0052-LPU19, 
por la adquisición de leche en polvo en el marco del Programa "Vaso de Leche por Día", impulsada por el Ministerio de Desarrollo Social, implicando la autorización conferida el importe de pesos cuatrocientos un millones quinientos veinte mil (\$401.520.000,00).

iii. Proceso de selección del cocontratante.

a) Se registra un proceso de selección del cocontratante de excepción en razón del sujeto (con el Ministerio de Seguridad -POLAD-), bajo el encuadre legal previsto en artículo 18 apartado 2) inciso a) de la Ley $\mathrm{N}^{\circ} 13.981$ y su Decreto $\mathrm{N}^{\circ} 1300 / 16$ impulsado por el Ministerio de Salud, aprobado por Decreto $N^{\circ} 15 / 19$, para la prestación del servicio de Policía Adicional, por un importe de pesos doscientos noventa millones cuarenta y tres mil seiscientos ( $\$ 290.043 .600,00)$, modificado por el Decreto $N^{\circ} 246 / 19$ en la suma de pesos trescientos cincuenta y ocho millones setecientos mil cuatrocientos noventa y seis $(\$ 358.700 .496,00)$ a raíz de la actualización del valor hora de servicio conforme a la Resolución del Ministerio de Seguridad No 7/19.

Asimismo, y con sus particularidades, puede englobarse en la presente categoría al Decreto $N^{\circ} 145 / 19$, través del cual se ratificó la Resolución $N^{\circ} 443 / 19$ del Instituto Provincial de Lotería y Casinos de la Provincia de Buenos Aires, que prorrogara, a partir de la fecha de su vencimiento -31 de diciembre 2018-, los términos de los contratos aprobados por Decretos $N^{\circ} 836 / 07$ y $\mathrm{N}^{\mathrm{o}}$ 2400/02, referentes al funcionamiento del Casino de Mar del Plata y de Tandil, respectivamente, ambos con la firma Boldt S.A. seleccionada directamente, hasta el 30 de junio de 2019 o momento de entrada en vigencia del nuevo contrato con el/los proveedores que resulten adjudicatarios en el proceso licitatorio $\mathrm{N}^{\circ} 1 / 18$, de resultar anterior a dicha fecha.

Cabe acotar que desde que se suscribieron los mismos, aprobado el primero en el marco de las previsiones del artículo 26 inciso 3 d) del Decreto-Ley de Contabilidad $N^{0} 7.764 / 71$ y el segundo de ellos careciendo el texto del decreto de encuadre legal, fueron prorrogados sucesivamente, tal como da cuenta 
el artículo 1 de la Resolución citada “...los términos de los contratos aprobados por Decretos $N^{\circ} 836 / 07, N^{\circ} 2400 / 02$ prorrogados por Resoluciones $\mathrm{N}^{\mathrm{o}} 1765 / 12$ - ratificada por Decreto $\mathrm{N}^{\circ}$ 913/13-; $\mathrm{N}^{\circ}$ 910/14 -ratificada por Decreto $\mathrm{N}^{\circ}$ 784/14-; $\mathrm{N}^{\circ} 2488 / 14$-ratificada por Decreto No $901 / 16$-; No $297 / 16$-ratificada por Decreto $\mathrm{N}^{\circ} 901 / 16-; \mathrm{N}^{\circ} 1893 / 16$-ratificada por Decreto $\mathrm{N}^{\mathrm{o}}$ 16-E/2017-; No 674/17 -ratificada por Decreto $\mathrm{N}^{\circ} 438-\mathrm{E} / 17-; \mathrm{y}$ $\mathrm{N}^{\mathrm{o}}$ RESOL-2018-303-GDEBAIPLYCMJGM -ratificada por Decreto $\mathrm{N}^{\circ}$ DECTO-2018-350-GDEBA-GPBA-; suscriptos entre el Instituto Provincial de Lotería y Casinos y "Boldt S.A."

b) Por otro lado, se registraron los siguientes procedimientos de selección de Licitación Pública, con encuadre en lo establecido en el artículo 17 de la Ley $\mathrm{N}^{\circ}$ 13.981:

El Decreto $N^{\circ}$ 668/19 - impulsado por el Ministerio de Justicia- por el cual se autorizó el llamado a Licitación Pública y se aprobaron las bases concursales, para contratar el servicio de monitoreo electrónico para supervisar a mil seiscientos (1.600) internos/as por radiofrecuencia y a cuatrocientos (400) internos/as por rastreo GPS, incluyendo ambas modalidades verificación de identidad por reconocimiento de voz y la provisión de equipamiento necesario, con destino a la Dirección de Monitoreo Electrónico dependiente de la Dirección General de Seguridad del Servicio Penitenciario Bonaerense, por un plazo de prestación de setecientos treinta (730) días corridos. Dicho proceso tramitó bajo el Proceso de Compra $\mathrm{N}^{\circ}$ 1640037-LPU19 y fue aprobado y adjudicado mediante Decreto $\mathrm{N}^{\mathrm{0}} 1344 / 19$ por la suma de pesos mil cuatrocientos setenta millones ochocientos cuatro mil ( $\$ 1.470 .804 .000,00)$.

Por otro lado, el Ministerio de Desarrollo Social impulsó el Decreto $N^{\circ} 705 / 19$, por el cual se aprobó la Licitación Pública $\mathrm{N}^{\circ} 4 / 19$, Proceso de Compra $\mathrm{N}^{\circ} 445-0052-\mathrm{LPU} 19$, tendiente a la adquisición de dos millones cien mil (2.100.000) kilos de leche en polvo para el Programa "Vaso de Leche por Día" y se adjudicó por la suma de pesos quinientos un millones novecientos mil $(\$ 501.900 .000,00)$. 
El Decreto $\mathrm{N}^{\circ} 817 / 19$, por su parte, impulsado por el Ministerio de Justicia, aprobó la Licitación Pública $\mathrm{N}^{\circ} 164$ 0126-LPU18, tendiente a contratar la provisión de gas licuado propano a granel, con destino a distintas Unidades Carcelarias y Establecimientos Penitenciarios, con un plazo de entrega de 730 días desde la formalización del contrato, adjudicado por la suma de pesos seiscientos dos millones veintiún mil ciento noventa y cinco $(\$ 602.021 .195,00)$.

El Decreto No $1235 / 19$, impulsado por el Ministerio de Salud, por el cual se aprobó la Licitación Pública (Proceso de Compra $\mathrm{N}^{\circ}$ 99-0155-LPU18) para la adquisición de insumos médicos con destino al Banco de Drogas dependiente del Ministerio de Salud de la Provincia de Buenos Aires, por un monto total de pesos novecientos ochenta y tres millones doscientos sesenta y cuatro mil ochenta y cuatro con treinta y cuatro centavos (\$983.264.084,34).

De los decretos citados cuatro (4) fueron bajo el régimen del Decreto Reglamentario $N^{\circ} 1300 / 16$, vigente al momento del dictado del acto administrativo que autorizó la contratación (Decretos $\mathrm{N}^{\mathrm{o}}$ 15/19, No 246/19, No 817/19 y $\mathrm{N}^{\mathrm{o}} 1235 / 19$ ) y tres bajo la reglamentación aprobada por el Decreto $\mathrm{N}^{\circ} 59 / 19$ ( $N^{\circ}$ 668/19, No 1344/19 y No 705/19).

Como se había citado, por Decreto No $145 / 19$ se habilitó la prórroga, a partir de la fecha de su vencimiento -31 de diciembre 2018-, de los contratos aprobados por Decretos $N^{\circ} 836 / 2007$ y $\mathrm{N}^{\mathrm{o}} 2400 / 2002$, referentes al funcionamiento del Casino de Mar del Plata y de Tandil, respectivamente, ambos con la firma BOLDT S.A. seleccionada directamente, hasta el 30 de junio de 2019 o momento de entrada en vigencia del nuevo contrato con el/los proveedores que resulten adjudicatarios en el proceso licitatorio $\mathrm{N}^{\circ} 1 / 18$, de resultar anterior a dicha fecha.

Dicha Licitación Pública $\mathrm{N}^{0} 1 / 18$, se encuadró en las previsiones del artículo 17 de la Ley $\mathrm{N}^{\circ} 13.981$ y en el artículo 17 apartado 1 -Licitación Pública- y apartado 2 -de Etapa Múltiple- del Anexo I del Decreto $N^{o} 1300 / 16$, impulsada para la 
contratación de un servicio integral, cuyo objeto consiste en la provisión y mantenimiento de Máquinas Electrónicas de Juegos de Azar Automatizadas, el Control On-Line de las mismas, la remodelación, construcción y/o cesión y puesta en valor de las distintas Salas de Juego y diversos Servicios Complementarios y anexos a la actividad lúdica, y puesta en valor de las distintas Salas de los Casinos Oficiales de la Provincia de Buenos Aires, Central Mar del Plata, Casino Anexo III de Mar del Plata (Hotel Hermitage), Casino de Miramar, Casino de Monte Hermoso, Casino de Pinamar, Casino de Tigre y Casino de Tandil.

Por el Decreto N$^{\circ} 182 / 19$ se aprobó la referida contratación, por un período de veinte (20) años contados a partir de la fecha de suscripción del contrato, con posibilidad de prórroga de un (1) año adicional, a opción del Instituto Provincial de Lotería y Casinos, y se adjudicó el Renglón $\mathrm{N}^{\mathrm{0}} 1$ (Casino de Tigre y Casino de Pinamar) al oferente "Boldt S.A", el cual contará como única retribución el porcentaje de cincuenta y tres por ciento $(53 \%)$ de la rentabilidad mensual producida por la explotación de las máquinas electrónicas de juego de Azar que se instalen, los casinos referidos y el Renglón $\mathrm{N}^{\mathrm{o}} 3$ (Casino Central de Mar del Plata y Casino Monte Hermoso) al oferente "Casino de Victoria S.A" el cual contará como única retribución el porcentaje de cincuenta y cinco coma cinco por ciento $(55,5 \%)$ de la rentabilidad mensual producida por la explotación de las máquinas electrónicas de juego de Azar que se instalen los casinos mencionados.

Cabe resaltar que el Renglón $\mathrm{N}^{\mathrm{o}} 2$ conformado por el Casino de Tandil, Casino de Miramar y Casino Anexo III de Mar del Plata (Hotel Hermitage) quedó fracasado.

\section{II.2.12. Decretos de legítimo abono}

En el año 2019 se registró un (1) decreto de reconocimiento del gasto y autorización del pago bajo la denominada figura del "legítimo abono".

Por el Decreto $\mathrm{N}^{\circ}$ 533/19 tramitado en expediente EX2018-29135099-GDEBA-DDPRYMGEMSGP, se reconoció el gasto 
y se autorizó el pago de la suma de ciento cuarenta y siete millones seiscientos veintitrés mil cuatrocientos noventa y seis con noventa centavos $(\$ 147.623 .496,90)$, a favor de la firma Telefónica de Argentina S.A., por la provisión del Servicio de Soporte y Mantenimiento Integral de Emergencias 911, durante el período comprendido entre los meses de enero a agosto del año 2018, en el marco del Proyecto BID 2210/OC-AR "Programa de Seguridad Ciudadana e Inclusión de la Provincia de Buenos Aires" (PSCI).

El acto fue dictado en uso de las atribuciones conferidas por el Decreto $\mathrm{N}^{\circ}$ 523/18 y artículo 144 -proemio- de la Constitución de la provincia de Buenos Aires, estableciendo en su artículo $4^{\circ}$ que "una vez efectuado el gasto, deberán remitirse las presentes actuaciones a la Contaduría General de la Provincia a los fines de su evaluación en los términos de los artículos 104, 112 y 113 de la Ley No 13.767 y su Decreto Reglamentario."

Conforme al seguimiento del expediente citado, si bien la Orden de Pago se autorizó el 05 de junio de 2019 y se pagó el 13 del mismo mes, al 11 de septiembre de 2020 el expediente no fue remitido a la Contaduría General de la Provincia.

\section{II.2.13. Decretos relativos a las funciones colegislativas del} Poder Ejecutivo: promulgación de leyes y veto

En relación al ejercicio de las funciones colegislativas, el Poder Ejecutivo participa en la formación de las leyes mediante la promulgación y publicación (art. 108 y concordantes de la Constitución Provincial). En ese contexto, debemos señalar que durante el 2019 se dictaron únicamente tres (3) decretos promulgatorios de leyes; al tiempo que no se registró que la entonces Gobernadora haya hecho uso de la prerrogativa constitucional de veto durante el período en análisis.

Sobre el particular, es dable resaltar que, de los tres (3) actos administrativos mencionados, dos (2) refieren a leyes sancionadas por el Poder Legislativo los últimos días de 2018. Estos son los Decretos $\mathrm{N}^{\circ} 11 / 19$ y N $12 / 19$, mediante los cuales se 
promulgaron las Leyes $\mathrm{N}^{\circ} 15.109$ y $\mathrm{N}^{\circ} 15.110$, respectivamente. El restante, Decreto $\mathrm{N}^{\circ}$ 245/19, promulgó la Ley $\mathrm{N}^{\circ} 15.134$, mediante la cual, en el marco de la Ley Nacional $\mathrm{N}^{\circ} 27.499$ denominada "Ley Micaela de Capacitación Obligatoria en Género para todas las personas que integran los tres poderes del Estado", se estableció la capacitación obligatoria en la temática de género y violencia contra las mujeres para todas las personas que se desempeñen en la función pública, en todos sus niveles y jerarquías, en forma permanente o transitoria, ya sea por cargo electivo, designación directa, por concurso o por cualquier otro medio legal, en el ámbito de los tres poderes del Estado provincial.

Cabe destacar que, en todos los casos, la facultad constitucional se ejerció al límite del plazo previsto en el artículo 108 de la norma fundamental provincial. En ese sentido, los dos primeros decretos se dictaron en el décimo día hábil desde que fuera comunicada la norma al Poder Ejecutivo, mientras que el primero lo fue al noveno día hábil.

Sobre la temática analizada, durante 2018 se registraron un total de diecinueve (19) decretos: dieciséis (16) promulgatorios y tres (3) vetos, de los cuales uno (1) fue total y dos (2) fueron parciales. La explicación a la abrupta caída en la cantidad de decretos referidos a la temática, se relaciona con el número de leyes sancionadas por la Honorable Legislatura provincial en cada uno de los períodos. Así, mientras que durante el 2018 se sancionaron ciento doce (112) leyes, en todo el 2019 fueron sancionadas treinta y seis (36), de las cuales treinta (30) lo fueron durante el período comprendido entre el $1^{\circ}$ de enero y el 10 de diciembre.

Al respecto, consideramos pertinente mencionar que durante 2018 la entonces Gobernadora se expidió expresamente sobre el dieciséis con noventa y seis por ciento (16,96\%) de las leyes sancionadas, mientras que durante el período objeto del presente del año 2019, lo hizo sobre el diez por ciento (10\%). Si bien la proporción continúa siendo menor, la diferencia se reduce significativamente. 
Por otro lado, resulta de interés señalar que, de las treinta (30) leyes sancionadas en el plazo que se analiza en el presente trabajo, diecisiete (17) declaran personalidad destacada o ciudadano ilustre ${ }^{50}$.

\section{II.2.14. Reglamentos Ejecutivos}

En oportunidad de tratar el reglamento como especie de acto administrativo en la publicación anterior de la presente investigación, se referenciaron los cuatro tipos de reglamentos, a saber: ejecutivo, autónomo, delegado y de necesidad y urgencia.

Con relación al reglamento ejecutivo, se señaló que, como atribución del Poder Ejecutivo conferida por el inciso $2^{\circ}$ del

50 Como dijimos, la Ley № 15.134 de Capacitación Obligatoria en Género para todas las personas que integran los tres poderes del Estado, fue promulgada expresamente por el Decreto $\mathrm{N}^{0} 245 / 19$. A continuación, listamos las restantes doce (12) leyes que fueron promulgadas tácitamente durante el período comprendido entre el $1^{\circ}$ de enero y el 10 de diciembre de 2019: Ley № 15.136 - Otorga al Yacht Club Argentino, permiso de uso y goce de la fracción de tierra y espejo de agua donde funcionan sus instalaciones, ubicado en el partido de General Pueyrredón (puerto de Mar del Plata). Ley N 15.137 - Declara Fiesta Provincial a la denominada "Fiesta de la harina", Ilevada a cabo anualmente el mes de abril, teniendo como sede a la ciudad de Alberti. Ley N 15.138 - Declara Saladillo como "Capital Provincial del Helicóptero Argentino". Ley N 15.139 - Modifica el artículo 11 del Título IV "Consejo Provincial de Seguridad Vial" de la Ley N 13.927 (Código de Tránsito). Ley N 15.141 - Declara "Paisaje Protegido de Interés Provincial" a la zona de desarrollo eco-turístico de Arenas Verdes, partido de Lobería. Ley N 15.142 - Declara "Monumento Histórico Provincial", en los términos de la ley $N^{0} 10.419$ y sus modificatorias, al Monumento a Evita, sito en la localidad de los Toldos, partido de General Viamonte. Ley N ${ }^{0} 15.143$ - modifica las Leyes N ${ }^{0} 13.927$ y № 14.547 (Código de Tránsito - obligatoriedad - chaleco reflectante - casco reglamentario - ciclomotor - motocicleta - triciclos motorizados - cuatriciclos - estaciones de servicio - prohibición - notificación por infracción o falta). Ley № 15.144 - Suspende por 180 días las acciones judiciales, trámites y/o diligencias que tengan por objeto ordenar y/o ejecutar el desalojo de la Cooperativa de Trabajo el Amanecer Ltda, de la localidad de Burzaco, partido de Almirante Brown. Ley N ${ }^{0} 15.146$ - Declara a la ciudad de Carmen de Patagones, perteneciente a la “Comarca Viedma-Carmen de Patagones" como cuna del canotaje. Ley N 15.147 - Prórroga por el término de 1 año la vigencia de la Ley $\mathrm{N}^{0}$ 14.262, modificada por las Leyes $\mathrm{N}^{0} 14.366$, $\mathrm{N}^{0} 14.521, \mathrm{~N}^{0} 14.593, \mathrm{~N}^{0} 14.713, \mathrm{~N}^{0} 14.826, \mathrm{~N}^{0} 14.935$ y $\mathrm{N}^{0} 15.120$, a partir de la fecha de vencimiento de esta última (inembargabilidad-clubes). Ley $N^{0} 15.148$ - Modifica el artículo $1^{\circ}$ de la Ley N 14.820 referente al "Día del Bibliotecario". Ley Nº 15.149 - Dispone la donación de diferentes inmuebles a la Municipalidad de Roque Pérez, con el cargo de destinarlos a "vivienda única, familiar, de uso propio y de ocupación permanente". 
artículo 144 de la Constitución bonaerense, es el acto administrativo tendiente a hacer ejecutar las leyes de la Provincia $\mathrm{y}$, en tal sentido, la actividad reglamentaria se realiza siempre secundum legem, completando la ley y regulando detalles indispensables para asegurar su cumplimiento.

Cabe recordar que, además de la intervención en el procedimiento de los organismos de la Administración con competencia material -primaria o secundaria-, al tratarse de actos de carácter general, estos son también sometidos, antes de su dictado, al dictamen jurídico del Asesor General de Gobierno y la vista del Fiscal de Estado (art. 123 del Decreto Ley $\mathrm{N}^{\mathrm{0}}$ 7647/70). Asimismo, es requerida la intervención previa, mediante informe, de la Contaduría General de la Provincia, en caso de que se deban interpretar las disposiciones legales y reglamentarias en materia de su competencia y asesorar en dicho aspecto a los organismos de la Administración provincial (art. 90 inc. b) Ley $\mathrm{N}^{\circ}$ 13.767). Ello, en concordancia con el artículo 104 inc. d) del Decreto $\mathrm{N}^{\circ}$ 3260/08 (reglamentario de la Ley $\mathrm{N}^{\circ}$ 13.767) que establece que ejerce, en cualquier etapa sustancial, el control previo de los actos que impliquen o afecten, de manera directa o indirecta, el patrimonio del Estado o que supongan cualquier erogación, gasto, ingreso o egreso de bienes al mismo.

A continuación, pasamos revista de los diecisiete (17) decretos reglamentarios dictados por el Poder Ejecutivo en 2019, haciendo una breve reseña de cada uno:

a) Decreto $N^{\circ}$ 43/19: aprueba la reglamentación de la Ley $\mathrm{N}^{\mathrm{o}} 13.951^{51}$ "Régimen de Mediación en Conflictos Judiciales". También, designa al Ministerio de Justicia ${ }^{52}$ como Autoridad de Aplicación de la ley y administrador del Fondo de Financiamiento

\footnotetext{
51 La Ley № 13.951 establece el régimen de mediación como método alternativo de resolución de conflictos judiciales en el ámbito de la Provincia (art. $1^{\circ}$ ); la que será obligatoria previo a todo juicio, con las exclusiones contempladas (art. $2^{\circ}$ ); y voluntaria como instancia previa a la Mediación Obligatoria (art. $3^{\circ}$ ).

52 Actual Ministerio de Justicia y Derechos Humanos, Ley Nº 15.164.
} 
del Registro Provincial de Mediadores y para el funcionamiento del Sistema de Mediación.

Entre los fundamentos invocados para reemplazar la reglamentación vigente a ese momento, aprobada por Decreto $\mathrm{N}^{\mathrm{o}} 2530 / 10$, modificada por los Decretos $\mathrm{N}^{\mathrm{o}} 132 / 11$ y $\mathrm{N}^{\mathrm{o}} 359 / 12$, podemos citar: i) la experiencia recabada luego de transcurridos cinco (5) años desde la implementación del mecanismo de resolución de conflictos; ii) que durante el proceso de elaboración de la reforma fueron consultadas instituciones académicas, colegios profesionales y los mediadores y mediadoras que ejercen cada día su profesión; y iii) la necesidad de unificar las pautas de procedimiento que rigen la mediación voluntaria y obligatoria.

b) Decreto $N^{\circ}$ 59/19: mediante la Ley $N^{\circ} 13.981$, que este decreto reglamenta, se incorporó el Subsistema de Contrataciones del Estado Provincial al Sistema de Administración Financiera del Sector Público de la Provincia de Buenos Aires previsto en la Ley $\mathrm{N}^{\mathrm{O}}$ 13.767, incorporando la mencionada norma una regulación detallada del instituto del contrato administrativo, tanto en su etapa procedimental, como en su regulación sustantiva, mediante la incorporación de principios, derechos y prerrogativas que regulan su ejecución.

El Subsistema de Contrataciones se publicó en el Boletín Oficial No 26.115 del 27 de abril de 2009, sin embargo, la propia ley (en su texto y producto de posteriores reformas) se encontraba condicionada en su vigencia al dictado de la norma reglamentaria, lo que se produjo recién en el año 2010, mediante el Decreto $\mathrm{N}^{\circ} 1300 / 16$.

El referido decreto tuvo por objeto, según emerge de su parte considerativa, instrumentar medidas tendientes a la modernización de los procesos administrativos de adquisición de bienes y servicios, así como su adecuación a las nuevas tecnologías, a fin de dar cumplimiento al mandato constitucional de promover el bienestar general. Además, se propuso reforzar los ejes centrales para la gestión pública dotando a la Administración Pública provincial de las herramientas necesarias para 
la transformación de las estructuras burocráticas y que aporten soluciones a las necesidades ciudadanas.

Poco más de dos (2) años después, el 4 de febrero de 2019, se dictó el Decreto $\mathrm{N}^{\circ}$ 59, norma que procuró incorporar la experiencia recogida en el transcurso del tiempo desde la vigencia del Decreto $\mathrm{N}^{\circ} 1300 / 16$ y determinados cambios en las estructuras orgánicas de las jurisdicciones provinciales, circunstancias que exigían una readecuación normativa con la finalidad de adaptarla a las necesidades del interés público.

La implementación de Ley $\mathrm{N}^{\circ} 13.981$, por medio de su reglamentación (primero con la impartida por el Decreto $\mathrm{N}^{\circ} 1300 / 16$ y luego con la aprobada por el Decreto $N^{\circ} 59 / 19$ ), ha reportado como ventaja distintiva la adopción de un sistema de compra electrónica (actualmente el PBAC), que a la vez incorporan distintas modalidades de contratación, tendientes a favorecer la adquisición centralizada y rápida de determinados bienes y servicios.

El paso inicial dado por el legislador, hace ya once (11) años, previendo expresamente la incorporación de las herramientas que hacen a la nueva gestión pública y las tecnologías de la información y la comunicación para mejorar la tramitación de los procesos de compra en aras de lograr celeridad, transparencia y eficacia, y la implementación posterior a través de su reglamentación, han marcado un hito local en materia de contrataciones.

Sin embargo, debe destacarse una circunstancia coyuntural que acompañó la vigencia de ambos reglamentos, que consistió en las declaraciones de emergencia sobre siete (7) ámbitos (administrativa, tecnológica, infraestructura, hábitat, vivienda, servicios públicos, seguridad pública, política y salud penitenciaria) instrumentadas por tres (3) leyes sancionadas en los primeros meses del 2016 (Leyes $\mathrm{N}^{\mathrm{o}} 14.806, \mathrm{~N}^{\mathrm{o}} 14.812$ y No 14.815$)^{53}$

53 Actualmente estas leyes se encuentran prorrogadas por Ley № 15.165. La que, además, extiende el estado de emergencia al ámbito social, económico, productivo y energético (artículo $1^{\circ}$. 
normas que contenían, cada una de ellas y de forma distinta, regímenes especiales y de excepción para realizar contrataciones públicas; las que, además, fueron sucesivamente prorrogadas hasta abarcar todo el mandato constitucional del Poder Ejecutivo.

Si bien, en el contexto de emergencia -por prolongado que sea- los procedimientos abreviados pueden ser un aporte a la solución de la coyuntura, y en tal sentido, resulta útil depositar energías allí, ello no debe implicar desatender el régimen general, como aspecto clave para contribuir al saneamiento de las cuentas públicas del Estado, que al fin de cuentas redunda en un beneficio de la comunidad.

Estos regímenes excepcionales, y de limitada extensión temporal, deberían, desde nuestro punto de vista, ser objeto de análisis, mediante su confrontación con el régimen general, dado que este último tiene vocación de comprender, incluso, aquellas circunstancias de emergencia, sin que, por lo tanto, estas requieran un apartamiento temporal.

En este sentido, el factor político debe aportar su visión para modelar la dinámica y progresiva modernización que requiere el Subsistema de Contrataciones, para que brinde los elementos necesarios para cumplir los objetivos de la gestión.

La progresividad del régimen jurídico de las contrataciones podría venir de la mano de un nuevo texto reglamentario que resuelva los obstáculos que las jurisdicciones vienen experimentando en el tiempo que lleva de aplicación la Ley $\mathrm{N}^{\mathrm{o}}$ 13.981, y que promueva mecanismos de compras unificadas

\footnotetext{
Declárase el estado de emergencia social, económica, productiva, y energética en el ámbito de la Provincia de Buenos Aires, como así también la prestación de los servicios y la ejecución de los contratos a cargo del sector público provincial, centralizado, descentralizado, organismos autónomos, autárquicos, de la Constitución, aun cuando sus estatutos, cartas orgánicas o leyes especiales requieran una inclusión expresa para su aplicación. Queda comprendido en la declaración de emergencia el Poder Ejecutivo de la Provincia de Buenos Aires, así como aquellos entes en los que el Estado Provincial se encuentre asociado con uno o varios Municipios. Los términos de la presente Ley se aplicarán a toda disposición que se dicte con posterioridad, siempre que se haga referencia expresa a la emergencia que se declara.)
} 
que trascienden el ámbito exclusivamente provincial y que puedan comprender contrataciones conjuntas y colaborativas con reparticiones nacionales o municipales.

c) Decreto $\mathrm{N}^{\circ} 70 / 19^{54}$ : estableció el marco normativo general para ser aplicado a la programación presupuestaria para el Ejercicio 2019.

Cabe tener presente que, luego de obtener la aprobación del presupuesto (o, frente a la omisión, su prórroga) la Ley $N^{o} 13.767$ (Administración Financiera) regula su etapa de ejecución; y, en ese marco, establece que corresponde al Poder Ejecutivo programar, para cada ejercicio, la ejecución física y financiera de aquel; ello con la finalidad de garantizar su correcta ejecución y compatibilizar los resultados esperados con los recursos disponibles.

En el mismo sentido, la Ley $\mathrm{N}^{\circ} 10.189$ (complementaria permanente de presupuesto) establece, en su artículo 45, que el Poder Ejecutivo a través del Ministerio de Economía, instruye a todas las jurisdicciones y entidades comprendidas sobre los alcances y modalidades de la programación presupuestaria.

En este sentido, el decreto en comentario se enmarca con una norma tendiente a establecer limitaciones y mecanismos para la ejecución del presupuesto.

Finalmente, cabe señalar que en la ejecución del presupuesto, conforme a la norma mencionada, el entonces Ministerio de Economía se encontraba facultado a fijar los importes máximos mensuales a comprometer; competencia que, además, le atribuye la reglamentación de la Ley $N^{\circ} 13.767$ (art. 34, Decreto $\mathrm{N}^{\mathrm{o}}$ 3260/08), al establecer las llamadas "cuotas de gastos de compromiso y devengado", resultando importante destacar que constituye una obligación de aquella jurisdicción -a fin de procurar la correcta ejecución- la de aprobarlas y comunicarlas.

54 Por Decreto N ${ }^{0} 1 / 2020$ se prorroga la programación presupuestaria para el Ejercicio 2020, como consecuencia de la Ley N 15.165 , que prorroga el Presupuesto General Ejercicio 2019 (Ley $N^{0}$ 15.078), para el Ejercicio 2020. 
d) Decreto $\mathrm{N}^{\circ}$ 131/19: reglamenta el artículo 39 de la Ley No 15.078 -Presupuesto 2019- a través del cual se crea un régimen de ayuda financiera destinado a financiar obras municipales, siendo el Ministerio de Infraestructura y Servicios Públicos la Autoridad de Aplicación.

La finalidad del decreto es ordenar el procedimiento tendiente a llevar a cabo las ayudas financieras, establecidas por Ley, a los diferentes municipios, estableciendo para ello requisitos tales como: proyectos alcanzados, documentación necesaria y evaluación de los mismos por parte de la Autoridad de Aplicación.

e) Decreto $N^{\circ}$ 181/19: este decreto reglamenta el Título VIII de la Ley No 15.079 -Impositiva 2019-, referido a la "Regulación del Juego on line"; aprueba el Régimen General de Convocatoria para el Otorgamiento de Licencias de Juego on line, y crea el Registro de Aspirantes a Licenciatario. Por último, faculta al Instituto Provincial de Lotería y Casinos, en su carácter de Autoridad de Aplicación a dictar las normas aclaratorias, interpretativas y complementarias.

El objetivo de la reglamentación es, a través de las habilitaciones de los juegos comprendidos en la ley y el registro de las licencias, asegurar el orden público, asumiendo el efectivo control sobre los juegos que se realicen bajo aquella modalidad, procurando evitar las apuestas de juegos de azar en sitios de internet no autorizados, a fin de erradicar el juego ilegal, evitar el fraude en el juego y el blanqueo de capitales.

f) Decreto $\mathrm{N}^{\circ}$ 265/19: reglamenta los artículos $3^{\circ}$ del Decreto-Ley $N^{\circ} 6769 / 58,148$ de la Ley $N^{\circ} 13.688$ y 13 bis de la Ley $\mathrm{N}^{\circ} 5.109$, en los términos de la Ley $\mathrm{N}^{\mathrm{o}} 14.836^{55}$, facultando a la Junta Electoral de la Provincia de Buenos Aires a adoptar

\footnotetext{
55 Ley N 14.836, Artículo $1^{\circ}$. Modifícase el artículo $3^{\circ}$ del Decreto Ley Nº 6769/58, “Ley Orgánica de las Municipalidades", el que quedará redactado de la siguiente manera: "Artículo $3^{\circ}$. El Intendente y los Concejales serán elegidos directamente por el pueblo, durarán en sus funciones el término de cuatro (4) años y podrán ser reelectos por un nuevo período.
} 
todas las medidas y dictar las normas operativas que estime pertinentes.

La Ley reglamentada regula el alcance de algunos derechos políticos -en particular, las limitaciones a las reelección-, y salariales de los/as Intendentes/as, Concejales/as, Consejeros/as escolares, Diputados/as y Senadores/as.

En lo sustancial, el decreto reglamenta las limitaciones establecidas en la ley, tales como la prohibición de reelección para un tercer mandato consecutivo establecida para Intendente/a, Concejales/as, Consejeros/as Escolares, Diputados/as y Senadores/as que, establece, abarca a quienes, habiendo sido reelectos en el mismo cargo para un segundo mandato consecutivo, hayan asumido sus funciones y ejercido por más de dos (2) años, continuos o alternados; la forma de cómputo del ejercicio de los cargos y sus reemplazos.

f) Decreto $\mathrm{N}^{\circ}$ 266/19: la Ley $\mathrm{N}^{\circ} 14.848$ de Participación Política Equitativa entre Géneros modificó el artículo 32 de la Ley $\mathrm{N}^{\circ}$ 5.109, estableciendo que las listas de candidatos a cuerpos colegiados a oficializarse deberán respetar una equivalencia del cincuenta por ciento (50\%) del género femenino y

Si han sido reelectos no podrán ser elegidos en el mismo cargo, sino con intervalo de un período. El concejo se renovará por mitades cada dos (2) años".

Artículo 4: Modifícase el artículo 148 de la Ley N 13688 y sus modificatorias "Ley de Educación", el que quedará redactado de la siguiente forma: "Artículo 148. Los Consejeros Escolares duran cuatro (4) años en sus funciones renovándose por mitades cada dos (2) años y podrán ser reelectos por un nuevo período. Si han sido reelectos no podrán ser elegidos en el mismo cargo, sino con intervalo de un período. Habrá además un número de Consejeros Escolares Suplentes igual al de Titulares. El número de Consejeros Escolares por Distrito varía de cuatro (4) a diez (10), de acuerdo a la cantidad de Establecimientos Educativos Públicos existentes de acuerdo a la siguiente escala: a) Hasta 60 Establecimientos Educativos: cuatro (4) Consejeros. b) Desde 61 hasta 200 Establecimientos Educativos: seis (6) Consejeros. c) Desde 201 hasta 350 establecimientos educativos: ocho (8) Consejeros. d) Desde 351 Establecimientos Educativos diez (10) Consejeros."

Artículo 5: Incorpórase a la Ley N 5109 el artículo 13 bis, con la siguiente redacción: "Artículo 13 bis: Los Diputados y Senadores podrán ser reelectos por un nuevo período. Si han sido reelectos no podrán ser elegidos en el mismo cargo, sino con intervalo de un período". 
otro cincuenta por ciento (50\%) del masculino, porcentajes que serán aplicables a la totalidad de la lista, la cual deberá cumplir con el mecanismo de alternancia y secuencialidad entre género por binomios (mujer- hombre u hombre-mujer). Asimismo, se estableció que cuando se trate de nóminas u órganos impares, la diferencia entre el total de hombres y mujeres no podrá ser superior a uno.

Además, modificó el artículo 11 de la Ley $N^{\circ}$ 14.086, estableciéndose que deberá respetarse la paridad para candidaturas femeninas y masculinas prevista en el artículo 32 de la Ley $\mathrm{N}^{\circ} 5.109$.

En tal sentido, el decreto comentado reglamenta la ley a efectos de que la paridad de géneros con mandato de posición se vea reflejada tanto en las listas de precandidatos presentadas en las elecciones primarias, abiertas, simultáneas y obligatorias (PASO) como en las listas de candidatos/as correspondientes a las Elecciones Generales.

g) Decreto $N^{\circ}$ 267/19: aprueba la reglamentación de la Ley $\mathrm{N}^{\mathrm{o}} 14.086$ que establece para el ámbito de la provincia de Buenos Aires el régimen de elecciones primarias, abiertas, simultáneas y obligatorias (PASO) para la selección de candidatos a cargos públicos electivos para todos los partidos políticos, agrupaciones municipales, federaciones y alianzas transitorias electorales, que deseen intervenir en la Elección General.

Al igual que el Decreto $N^{\circ} 265 / 19$, faculta a la Junta Electoral a adoptar todas las medidas y dictar las normas operativas que estime pertinentes a efectos de facilitar y garantizar la realización del acto electoral.

h) Decreto $N^{\circ}$ 531/19: aprueba la reglamentación de la Ley $\mathrm{N}^{\mathrm{o}} 11.459$, norma que regula el Certificado de Aptitud Ambiental exigible a las industrias instaladas o que se instalen dentro de la jurisdicción de la provincia de Buenos Aires; estableciendo que constituye un requisito indispensable para el otorgamiento de las correspondientes habilitaciones industriales por parte de los municipios. 
La reglamentación establece las actividades alcanzadas, por remisión al Nomenclador de Actividades aprobado por la Agencia de Recaudación de la Provincia de Buenos Aires (ARBA); el Nivel de Complejidad Ambiental (NCA) para la Clasificación de los Establecimientos Industriales en las categorías previstas en el artículo 15 de la Ley $\mathrm{N}^{\mathrm{o}} 11.459$, así como el detalle de las condiciones y trámite del Certificado requerido.

Por último, designa Autoridad de Aplicación al Organismo Provincial para el Desarrollo Sostenible (OPDS).

i) Decreto $\mathrm{N}^{\circ}$ 580/19: en cumplimiento con lo dispuesto en el artículo $4^{\circ}$ de la Ley $\mathrm{N}^{\circ} 15.134$, el mencionado decreto designa Autoridad de Aplicación, al Instituto Provincial de Género y Diversidad Sexual dependiente de la Secretaría de Derechos Humanos ${ }^{56}$ o el que en el futuro pudiera reemplazarlo, quedando facultado a dictar las normas interpretativas, complementarias y/o aclaratorias que resultaren necesarias.

Resulta oportuno destacar que la Ley $\mathrm{N}^{\mathrm{o}} 15.134$ establece el programa permanente de capacitación institucional en género y violencia contra las mujeres en el ámbito de provincia de Buenos Aires, conforme la Ley Nacional No 27.499 denominada "Ley Micaela de Capacitación Obligatoria en Género para todas las personas que integran los tres poderes del Estado". En otros términos, es la adhesión de la Provincia a la ley nacional ${ }^{57}$.

56 El Decreto N 45/2020 establece que el Ministerio de las Mujeres, Políticas de Géneros y Diversidad Sexual es Autoridad de Aplicación de la Leyes Nº 15.134 (de capacitación obligatoria en la temática de género y violencia contra las mujeres, en el marco de la Ley Micaela) y N $N^{0} 14.783$, en los términos de los Decretos N580/19 y N 1473/19 (art. 16).

57 Como antecedentes en la lucha contra este flagelo, podemos mencionar la Ley Nacional № 24.632 (publicada el 9 de abril de 1996), que aprobó la Convención Interamericana para Prevenir, Sancionar y Erradicar la Violencia contra la Mujer "Convención De Belem Do Para", suscripta el 9 de junio de 1994, por la cual "Los Estados partes condenan todas las formas de violencia contra la mujer, y convienen en adoptar, por todos los medios apropiados y sin dilaciones, políticas orientadas a prevenir, sancionar y erradicar dicha violencia".

Previo a la ley que aprobó la "Convención De Belem Do Para" se celebró en Beijing en el año 1995 la IV Conferencia Mundial sobre la Mujer, adoptada por 189 países, incluida la Argentina. En el encuentro se aprobaron una Declaración y un Programa de Acción. 
j) Decreto $N^{o}$ 669/19: modifica el ya citado Decreto $\mathrm{N}^{\mathrm{o}} 59 / 19$, reglamentario de la Ley $\mathrm{N}^{\mathrm{o}}$ 13.981, al tiempo que declara al servicio de enlace de datos como un servicio básico de telecomunicaciones de la Administración Pública provincial. Asimismo, crea el Registro Abierto y Permanente de Proveedores de Servicios de Enlace de Datos (R.A.P.P.S.E.D.), con el fin de inscribir a los prestatarios de dicho servicio, otorgando mayor certeza sobre la cantidad, asiento, capacidades técnicas y disponibilidad con la que cuentan los diferentes prestatarios.

En la Declaración los gobiernos se manifiestan decididos a intensificar los esfuerzos y acciones encaminados a alcanzar las metas de las Estrategias de Nairobi orientadas hacia el futuro para el adelanto de la mujer; a garantizar a todas las mujeres y las niñas todos los derechos humanos y libertades fundamentales, como la igualdad de acceso y la igualdad de trato de hombres y mujeres en la educación y la atención de salud y promover la salud sexual y reproductiva de la mujer y su educación, y tomar medidas eficaces contra las violaciones de esos derechos y libertades; a prevenir y eliminar todas las formas de violencia contra las mujeres y las niñas; entre otros.

La Plataforma de Acción es un programa encaminado a crear condiciones necesarias para la potenciación del papel de la mujer en la sociedad, con eje en doce esferas de especial preocupación.

En 2009 se sanciona y promulga la Ley N ${ }^{0}$ 26.485, de protección integral de las mujeres, busca prevenir, sancionar y erradicar la violencia.

Por Ley Nº 27.210 del año 2015 se crea el Cuerpo de Abogadas y Abogados para Víctimas de Violencia de Género, en el ámbito de la Secretaría de Justicia del Ministerio de Justicia y Derechos Humanos de la Nación, el que tendrá como misión garantizar el acceso a la justicia de las personas víctimas de violencia de género en consonancia con las prescripciones de la ley 26.485 de Protección integral para prevenir, sancionar y erradicar la violencia contra las mujeres en los ámbitos en que desarrollen sus relaciones interpersonales y hacer efectivo el ejercicio y goce de los derechos consagrados en ésta y otras normas relacionadas con la problemática.

Además, se instituye el día 11 de marzo de cada año, como el “Día Nacional de la Lucha contra la Violencia de Género en los Medios de Comunicación" (Ley N²7.176 de 2015).

Luego, la Ley N²7.234, también del mismo año, establece las bases para que en todos los establecimientos educativos del país, públicos o privados, de nivel primario, secundario y terciario se realice la jornada "Educar en Igualdad: Prevención y Erradicación de la Violencia de Género" con el objetivo de que los alumnos, las alumnas y docentes desarrollen y afiancen actitudes, saberes, valores y prácticas que contribuyan a prevenir y erradicar la violencia de género.

En 2019 se dicta la Ley № 27.533, cuyo objeto es visibilizar, prevenir y erradicar la violencia política contra las mujeres. 
Por último, designa Autoridad de Aplicación de las disposiciones del decreto en análisis al Ministerio de Jefatura de Gabinete de Ministros, al cual se faculta a dictar todas las normas aclaratorias y complementarias que faciliten su implementación,

k) Decreto $N^{\circ}$ 1036/19: dispone la modificación del artículo 41 del Decreto $\mathrm{N}^{\circ} 3260 / 08$, reglamentario de la Ley $\mathrm{N}^{\circ} 13.767$, a fin de asignar los recursos percibidos durante el año 2019, correspondientes a transferencias a percibir devengadas en 2018, de manera extrapresupuestaria, con destino a compensar las cuentas de recursos a percibir anticipadas en ejercicios anteriores.

1) Decreto $N^{\circ} 1236 / 19$ : aprueba la modificación del Decreto $\mathrm{N}^{\mathrm{o}} 1050 / 09$, reglamentario de la Ley $\mathrm{N}^{\mathrm{o}} 13.982$ - régimen estatutario para el personal de las policías de la provincia de Buenos Aires-, estableciendo nuevas pautas para el proceso de ascenso del personal policial, en lo relativo a la evaluación y calificación, dotando de este modo de nuevas competencias a la "Junta de Calificaciones".

m) Decreto $N^{o}$ 1288/19: reglamenta la Ley $N^{\circ} 14.761$, que crea el Fondo destinado al Financiamiento Operativo de las Federaciones y Asociaciones de Bomberos Voluntarios de la Provincia de Buenos Aires.

Además, designó Autoridad de Aplicación del mencionado régimen al Ministerio de Seguridad, a través de la Dirección Provincial de Defensa Civil, o la repartición que en el futuro la reemplace, con facultad de dictar las normas interpretativas, complementarias y aclaratorias que resulten necesarias. Finalmente, derogó la reglamentación anterior, aprobada por Decreto $\mathrm{N}^{\circ} 74 / 11$.

n) Decreto $\mathrm{N}^{\circ}$ 1473/19: aprueba la reglamentación de la Ley $\mathrm{N}^{\mathrm{o}} 14.783$, que tiene por objeto establecer como acción positiva la obligación de ocupar en el Sector Público de la provincia de Buenos Aires, en una proporción no inferior al uno por ciento (1\%) de la totalidad de su personal, a personas travestis, transexuales y transgénero. 
Designa Autoridad de Aplicación a la Secretaría ${ }^{58}$ de Derechos Humanos y al Ministerio de Trabajo, o la repartición que en el futuro las reemplace, quienes dictarán las normas interpretativas, complementarias y aclaratorias que resulten necesarias.

Ambas jurisdicciones deben crear una Comisión encargada de intervenir en el procedimiento de cobertura de vacantes y monitorear el cumplimiento del cupo; se establece, además, un deber de información de las jurisdicciones integrantes de la Administración hacia el Ministerio de Trabajo y la creación del "Registro Sacayán" para las postulaciones de quienes aspiren a ocupar las vacantes abiertas o reservadas por la ley.

ñ) Decreto $N^{\circ} 1698 / 19$ : este decreto designa autoridad de aplicación de la Ley $\mathrm{N}^{0} 15.105^{59}$ al Ministerio de Justicia ${ }^{60}$, a través de la Dirección de Entidades Profesionales o la repartición que en el futuro la reemplace, la cual dictará las normas interpretativas, complementarias y aclaratorias que resulten necesarias.

La Ley reglamentada tuvo por objeto la creación y regulación del Colegio de Profesionales de la Higiene y Seguridad en el Trabajo de la Provincia de Buenos Aires.

o) Decreto $\mathrm{N}^{\circ} 1786 / 19^{61}$ : aprueba la reglamentación de la Ley $\mathrm{N}^{\circ}$ 14.893, "Licencia para mujeres víctimas de violencia", destinada a todas las trabajadoras de la administración pública

58 El Decreto N 45/2020 establece que el Ministerio de las Mujeres, Políticas de Géneros y Diversidad Sexual es Autoridad de Aplicación de la Leyes № 15.134 (de capacitación obligatoria en la temática de género y violencia contra las mujeres, en el marco de la Ley Micaela) y N $N^{0} 14.783$, en los términos de los Decretos N580/19 y N 1473/19 (art. 16).

59 Crea el Colegio de Profesionales de la Higiene y Seguridad en el Trabajo de la Provincia de Buenos Aires.

60 Actual Ministerio de Justicia y Derechos Humanos, Ley N ${ }^{0} 15.164$.

61 Derogado por Decreto N 121/2020. La actual reglamentación dispone que “Cualquiera sea el régimen estatutario de la trabajadora y las modalidades de licencias y permisos que el mismo establezca, el otorgamiento de la Licencia para Mujeres Víctimas de Violencia, con las formas indicadas en el presente reglamento, es obligatorio para la Dirección Delegada de la Dirección Provincial de Personal u oficina de personal que haga sus veces en el Organismo 
o sociedades de economía mixta con participación estatal mayoritaria de la provincia.

No obstante, este Decreto no llegó a publicarse en el Boletín Oficial, dado que fue derogado por el Decreto $N^{\circ} 121 / 2020$ que reglamentó la mencionada licencia.

\section{II.2.15. Decretos de convalidación de ordenanzas municipales de ordenamiento territorial}

En 2019 el Poder Ejecutivo provincial dictó, en materia de ordenamiento urbano, seis (6) decretos convalidando ordenanzas municipales, con la siguiente configuración, a saber: dos (2) del Municipio de San Nicolás de los Arroyos (Decretos No 60/19 y $\mathrm{N}^{\circ}$ 146/19); uno (1) de Chacabuco (Decreto $\mathrm{N}^{\circ}$ 61/19); uno (1) de Zárate (Decreto $\mathrm{N}^{\circ}$ 95/19); uno (1) de Junín (Decreto $\mathrm{N}^{\mathrm{o}}$ 156/19) y, finalmente, uno (1) de Pilar (Decreto $\mathrm{N}^{\mathrm{o}} 45 / 19$ ).

Los expedientes mediante los cuales tramitaron los referidos actos fueron caratulados tres (3) en el Ministerio de Gobierno y los restantes en el Ministerio de Infraestructura y Servicios Públicos.

respectivo y su uso no podrá ser modificado, suspendido ni interrumpido por razones de servicio." (art. $3^{\circ}$ ).

Prevé un mecanismo de denuncia de fácil acceso, por lo tanto, no es admisible ningún tipo de traba burocrática ni dilaciones en el tratamiento: "Se entenderá por denuncia todo medio idóneo, por el que se haya puesto en conocimiento de un organismo estatal competente la situación de violencia referida, incluyéndose los distintos dispositivos y servicios de atención a víctimas." (art. 5\%).

Otra previsión de la norma, tendiente a animar a la víctima a realizar la denuncia por violencia contra toda conducta, acción u omisión, que de manera directa 0 indirecta, tanto en el ámbito público como en el privado, basada en una relación desigual de poder, afecte su vida, libertad, dignidad, integridad física, psicológica, sexual, económica o patrimonial, como así también su seguridad personal, y evitar, además, la re-victimización, es la que dispone que "Todas las dependencias, organismos y agentes que participen en el marco de la tramitación de la Licencia para Mujeres Víctimas de Violencia, así como los organismos y equipos de acompañamiento intervinientes, deberán preservar el derecho a la intimidad de la trabajadora y guardar estricta reserva sobre toda documentación e información a la que accedan, las que tendrán carácter reservado y confidencial, estableciéndose la prohibición de su reproducción o difusión por cualquier medio, debiendo codificarse su identidad en el informe de presentismo de manera especial." (art. 15). 
En comparación con el 2018, podemos observar una disminución significativa en la emisión de decretos sobre la temática, teniendo en cuenta que, en igual plazo, el año anterior se dictaron veintidós (22). Ello se debe a que, mediante Decreto $N^{\circ} 183 / 19$, del 25 de marzo, se delegó en el Ministro Secretario en el Departamento de Gobierno la aprobación establecida en el artículo 83 del Decreto-Ley No 8912/77 (T.O. 1987). Cabe tener presente que el referido precepto establece que ordenanzas correspondientes a las distintas etapas de los planes de ordenamiento podrán sancionarse una vez que dichas etapas fueren aprobadas por el Poder Ejecutivo, el que tomará intervención, previo dictamen de los Organismos Provinciales competentes, a los efectos de: a) verificar el grado de concordancia con los objetivos y estrategias definidos por el Gobierno de la Provincia para el sector y con las orientaciones generales y particulares de los planes provinciales y regionales de desarrollo económico y social y de ordenamiento territorial, así como el grado de compatibilidad de las mismas con las de los Municipios linderos; y b) verificar si se ajustan en un todo al marco normativo referencial dado por el referido decreto-ley y sus disposiciones reglamentarias, y si al prever ampliaciones de áreas urbanas, zonas residenciales extraurbanas e industriales, se han cumplimentado las exigencias contenidas en la misma para admitir dichos actos. Como se advierte, la norma determina que las etapas deben ser aprobadas por el Poder Ejecutivo provincial, previo a la sanción de la ordenanza. Sin embargo, la práctica demuestra que primero se sancionan las ordenanzas y, posteriormente, el Poder Ejecutivo las convalida. Tal es el caso de los seis (6) decretos sobre la materia dictados durante 2019.

Finalmente, podemos observar una disparidad en los plazos de tramitación de dichos decretos convalidatorios, pues varían de trescientos cuarenta y cinco (345) a dos mil ciento treinta y cuatro (2134) días, tales son los casos de las ordenanzas de los municipios de Zárate y San Nicolás de los Arroyos, convalidadas por Decretos $\mathrm{N}^{\circ}$ 95/19 y No 146/19. La situación planteada puede obedecer a diferentes causas, tal como se ha observado 
en la investigación de los decretos dictados en el año 2018, las cuales podrían englobarse en:

i. Cuestiones técnico-administrativas, por ejemplo, observaciones a nivel provincial de los organismos de contralor o del área técnica, que requiera rectificación por parte del municipio (ya sea de planos, de indicadores urbanísticos, entre otros), motivo por el cual el trámite vuelve a la comuna en más de una ocasión. Otro caso puede ser la falta de documentación o la existencia de documentación vencida, debiendo el municipio gestionar nuevos certificados ante el organismo correspondiente.

ii. Cuestiones político-institucionales, por ejemplo, que el Concejo Deliberante demore en sancionar la ordenanza, ya sea porque no se encuentre sesionando o por no contar con el quórum requerido.

\section{II.2.16. Decretos referidos a agrupamientos industriales}

i. Durante el período en análisis se dictaron cuatro (4) decretos referidos al tema del título, es decir, uno más que durante el 2018. Así, mediante los Decretos $N^{\circ}$ 247/19, $N^{\circ}$ 671/19, $\mathrm{N}^{\circ}$ 993/19 y No $1697 / 19$, se crearon el "Parque Industrial Privado San Vicente S.A.", en el Partido de San Vicente; el "Parque Industrial Privado Desarrollo Productivo S.A.", el "Parque Industrial Buen Ayre II", ambos en el partido de Moreno; y el "Sector Planificado Mixto Reconquista”, en el partido de San Miguel.

ii. Sentado ello, diremos que la Ley $N^{\circ} 13.744$ y su modificatoria, establece el régimen de creación y funcionamiento de Agrupamientos Industriales, aplicable en todo el territorio de la Provincia (art. 1). Entendiendo por tales, a los predios habilitados para el asentamiento de actividades manufactureras y de servicios, dotados de infraestructura, servicios comunes y equipamiento apropiado para el desarrollo de tales actividades. Los agrupamientos industriales se clasifican en: a) Parque Industrial, b) Sector Industrial Planificado, c) Área de Servicios Industriales y Logística, d) Incubadoras de Empresas, 
e) Unidades Modulares Productivas, y f) Parque Industrial Pequeño y Mediano (art. 2).

En el Título Segundo de la Ley se establecen los requisitos que las personas interesadas deben cumplimentar para que se acceda al decreto de aprobación, modificación o ampliación. Así, se indica, en primer término, que la solicitud puede ser presentada en forma independiente o conjunta por los siguientes sujetos: 1. Persona jurídica; 2. Asociación Gremial Empresaria y 3. Municipio, Provincia de Buenos Aires y/o Gobierno Nacional (art. 3).

El proyecto de Agrupamiento Industrial a ser evaluado por la Autoridad de Aplicación (al momento de realizar el presente, el Ministerio de Producción, Ciencia e Innovación Tecnológica) deberá contener la documentación que certifique la titularidad de las tierras, o encontrarse comprendido en los términos del artículo 26 inciso d) y los Informes de Factibilidad Municipal. Asimismo, el proyecto deberá contar con información referida a: a) tipo de agrupamiento y denominación propuesta para el mismo; b) medidas y superficie total del predio; c) aptitud hidráulica del predio; d) planimetría con la subdivisión del predio en parcelas y distribución de acceso y calles internas, en condiciones de presentar ante la Dirección Provincial de Geodesia; e) detalle referido a la provisión actual y proyectada de los servicios (comunicaciones, agua, energía eléctrica, gas, etc.) y sus redes de distribución interna; f) detalle del tratamiento y conducción de efluentes pluviales e industriales a cuerpo receptor; g) requerimientos particulares que establezca la reglamentación de acuerdo al tipo de agrupamiento; y h) proyecto de Reglamento de Administración y Funcionamiento (art. 4).

Una vez aprobada la solicitud mediante el dictado del pertinente decreto, el sujeto solicitante queda habilitado a iniciar las obras especificadas en el mismo (art. 7). Posteriormente, con el final de obra y el proyecto de Reglamento de Administración y Funcionamiento, la Autoridad de Aplicación evaluará el mencionado reglamento y la correspondencia entre las obras realizadas y el proyecto aprobado (art. 8). 
Finalmente, el reconocimiento concedido mediante acto administrativo habilitará al promotor del Agrupamiento a adjudicar parcelas o unidades funcionales dentro de los límites del mismo (art. 9).

iii. Respecto del procedimiento y áreas intervinientes, a grandes rasgos, podemos indicar que el expediente es iniciado por la Dirección Provincial de Industria dependiente de la Subsecretaría de Industria, Minería y Actividades Portuarias del Ministerio de Producción. Reunidos los extremos requeridos por la Ley $\mathrm{N}^{\mathrm{o}}$ 13.744, la Dirección de Planeamiento y Desarrollo Industrial, efectúa los análisis de factibilidad técnica y, de contar con dicho aval, se inicia el paso por los organismos de asesoramiento y control. Finalizando, mediante la suscripción del Decreto, previa intervención de la Secretaría Legal y Técnica.

\section{II.2.17. Decretos sobre tarifas de servicios públicos}

Durante el 2019 se dictó un (1) solo decreto respecto a la temática a analizar. Se trata del Decreto $\mathrm{N}^{\circ} 58 / 19$, el cual tuvo como finalidad principal modificar el régimen tarifario para la prestación de los servicios de provisión de agua potable y desagües cloacales.

Es dable destacar que, mediante los artículos $2^{\circ}$ y $3^{\circ}$ se establecieron medidas para no alterar el encasillamiento de los usuarios en los respectivos rangos, tanto para el sistema de facturación del servicio medido como del no medido; mientras que por el artículo $4^{\circ}$ se mantuvo la plena vigencia del régimen tarifario aprobado mediante Decreto $\mathrm{N}^{\circ} 3144 / 08$ y sus modificatorios, en lo que no fuera modificado por el decreto en análisis.

Cabe señalar que, de conformidad a lo establecido en el artículo $9^{\circ}$ de la Ley $\mathrm{N}^{\circ} 14.745$, mediante el cual se modificó el artículo 88 del Anexo del Decreto $N^{\circ} 878 / 03$, y sus modificatorias (convalidado por Ley $\mathrm{N}^{\mathrm{o}}$ 13.154), el 8 de enero de 2019, en el Salón Auditorio del Pasaje Dardo Rocha de la ciudad de La Plata, se dio cumplimiento a la audiencia pública convocada 
por la Autoridad del Agua de la provincia de Buenos Aires, a través de los diarios El Día, Ámbito y Clarín, los días 5, 6 y 7 de diciembre del 2018 y en el diario La Nueva de Bahía Blanca, los días 8, 9 y 10 de diciembre del 2018, con el objeto de informar los motivos de la solicitud de la variación tarifaria efectuada por Aguas Bonaerenses Sociedad Anónima (ABSA).

El acta de Audiencia fue suscripta por el entonces Presidente de ABSA y la entonces Subsecretaria Administrativa del Ministerio de Infraestructura y Servicios Públicos.

Por último, destacaremos que desde la caratulación de las actuaciones hasta la refrenda del decreto transcurrieron sesenta y ocho (68) días corridos.

\section{II.2.18. Decretos sobre subsidios}

i. Durante el periodo en análisis el Poder Ejecutivo suscribió dos (2) decretos otorgando subsidios a diversos municipios y a una Asociación Civil. Comparando con el año 2018, durante el cual se registraron trece (13) actos sobre esta materia, se advierte una reducción del ochenta y cinco por ciento (85\%) en el año 2019.

Cabe destacar que la baja cantidad de actos administrativos emitidos encuentra, en parte, su justificación en que, en su mayoría, estas subvenciones son otorgadas por las áreas correspondientes de los Ministerios.

ii. El primero de los subsidios en cuestión fue impulsado por la entonces Secretaría de Derechos Humanos y otorgado mediante Decreto $\mathrm{N}^{\circ} 1433 / 19$. A través de este acto, se aprobó un convenio con el Equipo Argentino de Antropología Forense Asociación Civil, otorgándole la suma de pesos un millón quinientos mil (\$1.500.000), a fin de solventar gastos de trabajos que realizaron en la Provincia en el marco de causas judiciales, la impermeabilización del techo de la sede central de la institución para asegurar la correcta conservación de muestras óseas bajo custodia de la entidad y la adquisición de equipos de computación. 
Si bien en la parte considerativa del referido decreto se menciona que se acompañó la documentación exigida por el Decreto $\mathrm{N}^{\mathrm{o}} 467 / 07$ y modificatorios, no se cita esa norma en párrafo del considerando correspondiente al encuadre legal, limitándose a mencionar que el mismo se dicta en el marco de las atribuciones conferidas por el artículo 144 -proemio- de la Constitución de la Provincia de Buenos Aires.

Por su parte, el segundo decreto tiene su origen en el ámbito del ex Ministerio de Desarrollo Social. El subsidio otorgado mediante Decreto $N^{\circ} 1474 / 19$ tuvo como finalidad solventar el gasto en concepto de Apoyo Económico para el desarrollo de la Etapa Final de los "Juegos Bonaerenses 2019", con destino a cuarenta y tres (43) Municipios, por un monto total de pesos cincuenta y un millones cincuenta y cinco mil ochocientos veinte (\$51.055.820).

El acto fue dictado en uso de las atribuciones conferidas por el artículo 144 -proemio- de la Constitución de la Provincia de Buenos Aires y conforme lo establecido por los Decretos $\mathrm{N}^{\mathrm{o}} 467 / 07$, sus modificatorios, y $\mathrm{N}^{\mathrm{0}} 70 / 19$.

Teniendo en cuenta este detalle, podemos señalar que el monto total en subsidios otorgado durante el 2019 es de pesos cincuenta dos millones quinientos cincuenta y cinco mil ochocientos veinte (\$52.555.820).

Si bien el número de decretos disminuyó considerablemente de un año a otro, no ocurre lo mismo con los montos totales. Así en el año 2018 ascendió a pesos cincuenta y cinco millones ciento cuarenta y nueve mil quinientos cincuenta con cincuenta y siete centavos $(\$ 55.149 .550,57)$, lo que nos arroja que se redujo sólo en un cinco por ciento (5\%) el monto total.

Por otro lado, observamos que las actuaciones tramitaron por expediente electrónico, insumiendo noventa y ocho (98) días corridos el Decreto $\mathrm{N}^{\circ} 1433 / 19$ y sesenta y nueve (69) días corridos el Decreto $N^{\circ} 1474 / 19$. 


\section{II.2.19. Decretos rectificatorios}

En este apartado analizaremos los decretos rectificatorios dictados en el 2019, período durante el cual la entonces Gobernadora refrendó cinco (5) actos relativos a diversas temáticas, a saber:

a) Decreto $\mathrm{N}^{\circ}$ 93/19: Por el cual, se rectificó el Decreto $\mathrm{N}^{\circ} 700 / 16$, mediante el cual se designó, a partir del 17 de febrero de 2016, a M. L. G. como Directora Ejecutiva del Hospital Zonal General de Agudos "Virgen del Carmen" de Zárate, en virtud de manifestar, la funcionaria designada, que tomó posesión del cargo el 4 de marzo del referido año. La rectificación fue encuadrada en el artículo 115 del Decreto-Ley $N^{\circ}$ 7647/70.

b) Decreto $N^{\circ}$ 94/19: Modificó el Decreto $N^{\circ} 725 / 17 \mathrm{E}$, por el cual tramitó la designación de N. F. P. en un cargo de médico asistente interino, especialidad: nefrología, como consecuencia de consignarse erróneamente la denominación de la especialidad en que debió ser designado.

c) Decreto $\mathrm{N}^{\mathrm{o}}$ 402/19: El mencionado acto administrativo enmendó el artículo $5^{\circ}$ del Decreto $\mathrm{N}^{\mathrm{o}}$ 1964/18 el régimen horario de los agentes designados por haberse consignado erróneamente.

d) Decreto No 559/19: Corrigió la fecha de la limitación de funciones de S.E.C. la cual fue dispuesta mediante Resolución No 1072/05 del Ministerio de Infraestructura y Servicios Públicos. Además, teniendo en consideración, lo resuelto en el mentado acto administrativo, se practicó un solapado reconocimiento de servicios.

e) Decreto $N^{\circ}$ 1432/19: Rectificó el artículo $2^{\circ}$ del Decreto $\mathrm{N}^{\mathrm{o}} 816 / 18$ mediante el cual se aprobó la desagregación de la estructura orgánico funcional, hasta el nivel de jefe/a de departamento, de la entonces Secretaría Legal y Técnica y de Asesoría General de Gobierno, determinando cuáles serían los cargos correspondientes y fijándose expresamente que "todos ellos conforme a los cargos vigentes que rigen en la Administración 
Pública Provincial; Ley $N^{\circ} 10.430$ y su Decreto Reglamentario $\mathrm{N}^{\mathrm{o}} 4.161 / 96$ (T.O. Decreto $\left.\mathrm{N}^{\mathrm{o}} 1.869 / 96\right)$ )., omitiendo consignar que la estructura mencionada contiene cargos susceptibles de ser cubiertos por agentes incluidos/as en el régimen establecido por la Ley $\mathrm{N}^{\circ} 10.449$.

Para finalizar señalaremos, a los fines comparativos, que en el año 2018 hubo siete (7) decretos referidos a la categoría analizada.

\section{II.2.20. Decretos no parametrizados}

En último lugar, englobamos bajo el rótulo de "no parametrizados" a los treinta y cinco (35) decretos dictados durante el período en análisis que no se corresponden con las categorías establecidas.

Se trata de actos de diferente naturaleza, dentro de los cuales encontramos, entre otros, la prórroga de las emergencias en materia de infraestructura, hábitat, vivienda y servicios públicos, y administrativa y tecnológica, mediante los Decretos $\mathrm{N}^{\circ} 270 / 19$ y $\mathrm{N}^{\mathrm{0}} 532 / 19$, respectivamente; la creación de los entes de derecho público no estatal Consorcio de Gestión del Puerto de Dock Sud (Decreto No 13/19), Consorcio de Gestión del Puerto de San Nicolás (Decreto No 96/19) y Consorcio de Gestión del Puerto de Coronel Rosales (Decreto No 584/19); la institución del Año Nuevo de los Pueblos Originarios el día correspondiente al solsticio de invierno para el hemisferio sur, a través del Decreto $\mathrm{N}^{\mathrm{o}}$ 672/19; y los llamados a concurso de antecedentes para cubrir cargos de vocales en el Tribunal Fiscal de Apelación, con título habilitante de contador/a (Decretos $\mathrm{N}^{\circ} 72 / 19$ y No 73/19) y de abogado/a (Decretos No 1095/19 y No 1096/19).

Nos parece pertinente destacar, entre los actos agrupados en esta categoría, al Decreto $N^{\circ}$ 268/19 mediante el cual, en uso de las atribuciones conferidas por el artículo 144 inciso $7^{\circ}$ y concordantes de la Constitución de la Provincia de Buenos Aires, la entonces Gobernadora convocó al electorado de la 
provincia de Buenos Aires para el día 27 de octubre de 2019 a la elección de: un (1) Gobernador y un (1) Vicegobernador; veintitrés (23) Senadores Provinciales Titulares y dieciséis (16) Suplentes; cuarenta y seis (46) Diputados Provinciales Titulares y veintiocho (28) Suplentes; ciento treinta y cinco (135) Intendentes Municipales; mil noventa y siete (1097) Concejales Titulares y setecientos seis (706) Suplentes; y cuatrocientos uno (401) Consejeros Escolares Titulares e igual número de Suplentes.

Asimismo, se convocó al electorado de la Provincia de Buenos Aires para el día 11 de agosto de 2019 a elecciones primarias, abiertas, simultáneas y obligatorias de candidatos/as a cargos públicos electivos para todos los partidos políticos, agrupaciones municipales, federaciones y alianzas transitorias electorales que deseen intervenir en la elección general.

Por otro lado, se estableció la simultaneidad de las elecciones primarias y generales de Gobernador y Vicegobernador, Legisladores Provinciales y Cargos Comunales con la de Presidente y Vicepresidente de la Nación, Diputados Nacionales aplicándose la normativa nacional en lo referente a: el padrón de electores nacionales, sin perjuicio de la utilización del padrón de electores extranjeros para las categorías provinciales de acuerdo a lo establecido en la Ley $\mathrm{N}^{\circ}$ 11.700; modelos de boletas; color de boletas; designación de autoridades de mesa; lugares de votación; escrutinio; y todo aquello compatible con el régimen de simultaneidad.

Finalmente, se dispuso la adhesión al régimen nacional de publicidad de campañas electorales, establecido en el Capítulo III Bis del Título III de la Ley No 26.215 y en el artículo 35 de la Ley Nacional No 26.571 .

\section{Palabras (cuasi) finales ${ }^{62}$}

En primer lugar, debemos decir que las tendencias que se marcaron en la investigación referida al 2018, se mantuvieron en

62 Como hemos hecho referencia a lo largo del trabajo, éste se inserta o entronca en una investigación más profunda respecto de los cuatro años de gobierno de María Eugenia Vidal 
el 2019, a excepción del período comprendido entre las elecciones primarias, abiertas, simultáneas y obligatorias (PASO) y la conclusión del período constitucional donde se aceleró el dictado de decretos en determinadas temática, entre ellas, designaciones de personal.

En ese orden, se advierte nuevamente un elevado número de decretos suscriptos por el Poder Ejecutivo provincial, sumando un total de mil ochocientos sesenta y tres (1863) contra los mil novecientos sesenta y nueve (1969) de 2018. Dentro de ese universo, al igual que el año anterior, la mayor cantidad de actos responde a trámites de personal, ascendiendo a mil cuatrocientos ochenta y cuatro (1484) decretos -en el año anterior, se registraron mil trescientos setenta y tres (1373)-. Es decir, si bien hubo una disminución en la cantidad de actos suscriptos por la entonces Gobernadora, los decretos referidos a trámites de personal aumentaron en un ocho por ciento (8\%).

Lo dicho reafirma la importancia temática de las cuestiones referidas al empleo público en la Provincia, cuyo volumen exhibe la necesidad de profundizar el estudio respecto al marco jurídico, los procedimientos administrativos involucrados y los requerimientos de la propia organización.

En segundo lugar, debemos señalar que en materia de género no se modificó el estado de situación oportunamente descripto para el 2018. Es decir, pese a lo dicho en la palestra pública por parte de la coalición gobernante, lejos se estuvo de una paridad de género en los cargos jerárquicos. Sin embargo, al igual que en nuestra anterior investigación, en lo referido a las designaciones temporarias o permanentes, si se muestra el equilibrio deseado -e incluso, en ambos casos, se registraron mayores ingresos del género femenino-.

Corresponde señalar, en materia de igualdad, que en el año analizado, mediante el Decreto $\mathrm{N}^{\circ} 1473$ del 5 de diciembre, se

en la Provincia. De allí entonces, que las palabras no deben ser interpretadas como finales, teniendo en cuenta que la investigación tiene como objeto temporal el período comprendido entre el 10/12/2015 y el 10/12/2019. 
reglamentó la Ley $\mathrm{N}^{\mathrm{o}} 14.783$ que asegura una proporción no inferior al uno por ciento de la totalidad del personal, a personas travestis, transexuales y transgénero, subsanando una omisión extendida desde finales del 2015.

Por su parte, en lo que respecta a la materia de estructuras orgánico-funcionales, debemos indicar que durante el 2018 se dictaron veinticuatro (24) decretos referidos a la materia, mientras que durante el período en análisis se registraron ocho (8) actos administrativos por los cuales se aprobaron estructuras organizativas; disminución que probablemente encuentra explicación en la publicación, en el último día hábil del 2017, de una nueva ley de ministerios (Ley $\mathrm{N}^{\circ}$ 14.989), circunstancia que motivó la adecuación de la organización a la norma, en el año precedente.

En tal sentido, se comprobó que seis (6) de los decretos dictados durante 2019 resultan ser modificaciones o ajustes a los aprobados en el 2018, tal como indicamos en el apartado correspondiente, y solo dos (2) a estructuras nuevas -Decretos $\mathrm{N}^{\mathrm{o}} 1247 / 19$ y $\mathrm{N}^{\mathrm{o}} 1345 / 19$, Ministerios de Asuntos Públicos y Gestión Cultural, respectivamente-.

En este punto, volvemos a reiterar una falencia, esto es, la falta de una norma de alcance general que regule la formulación, tramitación y aprobación de las estructuras gubernamentales. En la práctica, el límite -inevitable- a la creación o ampliación de unidades organizativas lo constituye el presupuesto legalmente aprobado, no obstante, la sola limitación económica no se presenta como un estándar que promueva una organización sustentada en criterios preestablecidos y orientados al cumplimiento de los objetivos, de modo que resulta una condición necesaria, pero no suficiente para un correcto diseño institucional. ${ }^{63}$

\footnotetext{
63 Esta situación, ya consignada en la investigación del período 2018, fue resuelta mediante el dictado el Decreto № 770/2020, por el cual se aprobó el “Reglamento para la Formulación, Tramitación y Aprobación de Estructuras Organizativas en el ámbito de la Administración Pública Provincial" y el "Modelo de Decreto de Aprobación/Modificación de Estructura Orgánico-Funcional"
} 
Por último, debemos indicar que el período investigado resultó ser el último año de gestión de la Gobernadora Vidal $y$, esta circunstancia, ha teñido esta porción de la actividad del Poder Ejecutivo, tanto en su objeto como en el ritmo de la gestión, provocando una aceleración en el dictado de decretos, a partir de los resultados en las elecciones primarias, abiertas, simultáneas y obligatorias (comúnmente denominadas, "PASO"), realizadas el 11 de agosto en el territorio provincial, el que se profundizó con los resultados del 27 de octubre de 2019 -comicios generales-. ${ }^{64}$

Al respecto, se señala que se formaron ciento siete (107) expedientes en el período julio/diciembre 2019. ${ }^{65}$

La mayor intensidad en la culminación de procedimientos administrativos y el dictado de los correlativos actos, se advierte, con notoriedad, en los períodos que van desde el 11 de agosto al 27 de octubre (53 días laborables, entre las PASO y comicios generales) y, fundamentalmente, entre el 28 de octubre y el 10 de diciembre (30 días laborables entre los comicios generales y el cambio de autoridades).

A modo de ejemplos, en materia de personal, en este último período (que representa un 13,04\% de días hábiles del año) se dictaron cuatrocientos tres (403) decretos, es decir, un veintisiete con dieciséis por ciento $(27,16 \%)$ del total; y, tomando los dos períodos (un 36,09\% de días hábiles del año), ese porcentaje se eleva al cuarenta y dos con setenta y nueve $(42,79 \%)$.

64 Debemos destacar que, a diferencia de lo previsto en la Constitución Nacional, en la provincia de Buenos Aires, se obtiene el triunfo a simple mayoría (conforme artículo 134 y concordantes de la Constitución Provincial).

65 Se recuerda que la provincia de Buenos Aires se adhirió mediante las leyes No 13.295 y № 15.036 a la ley $N^{0} 25.917$ (texto según Ley № 27.428), de Responsabilidad Fiscal, mediante la cual se regulan limitaciones al incremento del gasto corriente de carácter permanente, durante los dos (2) últimos trimestres del año de fin de mandato, con las únicas excepciones de aquellos que trasciendan la gestión de gobierno (así definidos normativamente) y deban ser atendidos de manera específica; y de los que tengan una causa originante anterior al período indicado y su cumplimiento sea obligatorio. 


\begin{tabular}{|c|c|c|c|c|c|c|}
\hline MATERIA & $\begin{array}{c}\text { \# Periodo } \\
\text { 11/08/2019 al } \\
27 / 10 / 2019\end{array}$ & $\begin{array}{l}\text { \# Impacto S } \\
\text { el Total de } \\
\text { Decretos }\end{array}$ & $\begin{array}{c}\text { \#Periodo } \\
\text { 28/10/2019 al } \\
10 / 12 / 2019\end{array}$ & $\begin{array}{l}\text { \# Impacto } \\
\text { s/ el Total } \\
\text { de Decretos }\end{array}$ & $\begin{array}{c}\text { \# Total } \\
\text { Decretos } \\
2019\end{array}$ & $\begin{array}{c}\# \\
\text { Representa } \\
\text { del Total }\end{array}$ \\
\hline Personal & 232 & $15,63 \%$ & 403 & $27,16 \%$ & 1484 & $42,79 \%$ \\
\hline Poder Judicial & 28 & $22,95 \%$ & 17 & $13,93 \%$ & 122 & $36,89 \%$ \\
\hline Procuracion & 12 & $15,79 \%$ & 3 & $3,95 \%$ & 76 & $19,74 \%$ \\
\hline Pollitica Salarial & 14 & $37,84 \%$ & 9 & $24,32 \%$ & 37 & $62,16 \%$ \\
\hline No Parametrizados & 6 & $17,14 \%$ & 9 & $25,71 \%$ & 35 & $42,86 \%$ \\
\hline Convenios & 6 & $21,43 \%$ & 6 & $21,43 \%$ & 28 & $42,86 \%$ \\
\hline Reglamentario & 2 & $11,76 \%$ & 3 & $17,65 \%$ & 17 & $29,41 \%$ \\
\hline Contrataciones & 3 & $18,75 \%$ & 1 & $6,25 \%$ & 16 & $25,00 \%$ \\
\hline Recurso Interpuesto & 1 & $12,50 \%$ & 3 & $37,50 \%$ & 8 & $50,00 \%$ \\
\hline Estructuras & 2 & $25,00 \%$ & 2 & $25,00 \%$ & 8 & $50,00 \%$ \\
\hline Corvalida Ordenanza & & & & & 6 & \\
\hline Rectificatorio & & & 1 & $20,00 \%$ & 5 & $20,00 \%$ \\
\hline Regimen Disciplinario & & & 4 & $80,00 \%$ & 5 & $80,00 \%$ \\
\hline Delegaciones & & & & & 4 & \\
\hline Parques Industriales & & & 1 & $25,00 \%$ & 4 & $25,00 \%$ \\
\hline Promulgatorio & & & & & 3 & \\
\hline Subsidios & & & 2 & $100,00 \%$ & 2 & $100,00 \%$ \\
\hline Legitimo Abono & & & & & 1 & \\
\hline Tarifa & & & & & 1 & \\
\hline Despacho & & & & & 1 & \\
\hline \multicolumn{7}{|c|}{ Emergencia Agropecuaria } \\
\hline \multicolumn{7}{|c|}{ Bienes } \\
\hline \multicolumn{7}{|l|}{ Veto Parcial } \\
\hline \multicolumn{7}{|l|}{ Caja de Policias } \\
\hline \multicolumn{7}{|c|}{ Honorarios Profesionales } \\
\hline \multicolumn{7}{|l|}{$\begin{array}{l}\text { Veto } \\
\text { Viaie al Exterior }\end{array}$} \\
\hline \multirow{2}{*}{\multicolumn{7}{|c|}{$\begin{array}{l}\text { Viaje al Exterior } \\
\text { Total }\end{array}$}} \\
\hline & & & & $24,91 \%$ & 1863 & $41,33 \%$ \\
\hline
\end{tabular}

llustración 26. Impacto sobre el total de decretos en el periodo posterior a las PASO hasta el cambio de autoridades. Fuente: elaboración propia.

Igual tendencia, e incluso más acentuada, se observa en los decretos referidos a la política salarial, en donde en el período elecciones generales - cambio de autoridades (13,04\%) se dictaron nueve (9) decretos, es decir, un veinticuatro con treinta y dos $(24,32 \%)$ del total; y, tomando los dos períodos $(36,09 \%)$, el porcentaje de decretos sobre el total se eleva al sesenta y dos con dieciséis por ciento $(62,16 \%)$. 
Estas circunstancias exhiben, desde el punto de vista institucional, la necesidad de ampliar las normas que regulen las transiciones gubernamentales, particularmente relevantes para una adecuada gestión del período final del mandato, en el que autoridades salientes y entrantes puedan construir consensos para ofrecer a la ciudadanía una continuidad no traumática del cambio de mando, que permita ordenar la salida para unos y, a la vez, aprovechar inmediatamente el período del mandato, apoyándose en bases ya fijadas, para otros.

La necesidad apuntada, no se exhibe solamente vinculada a cuestiones de ejecución presupuestaria o gestión de programas, sino que se extiende, incluso, a aspectos relevantes desde el punto de vista republicano, como lo es, a modo de ejemplo, la designación de magistradas y magistrados en la Procuración General y el Poder Judicial. 